medRxiv preprint doi: https://doi.org/10.1101/2020.10.15.20213025; this version posted October 20, 2020. The copyright holder for this preprint

(which was not certified by peer review) is the author/funder, who has granted medRxiv a license to display the preprint in perpetuity.

All rights reserved. No reuse allowed without permission.

\title{
Systematic review on chronic non-communicable disease in disaster settings
}

Christine Ngaruiya ${ }^{1}$, Robyn Bernstein ${ }^{2}$, Rebecca Leff ${ }^{1,3}$, Lydia Wallace $^{1}$, Pooja Agrawal ${ }^{1}$, Anand Selvam $^{1}$, Denise Hersey ${ }^{4}$, Alison Hayward ${ }^{5}$

${ }^{1}$ Department of Emergency Medicine, Yale University, New Haven, CT, USA

${ }^{2}$ Department of Chronic Disease Epidemiology, Yale School of Public Health, New Haven, CT, USA

${ }^{3}$ School of Medicine, Faculty of Health Sciences, Ben-Gurion University of the Negev, Beer -Sheva, Israel

${ }^{4}$ Director, Dana Medical Library, University of Vermont, Burlington, VT

${ }^{5}$ Divisions of Education and Global Health, Department of Emergency Medicine, The Warren Alpert Medical School of Brown University

Correspondence to:

Dr Christine Ngaruiya,

Department of Emergency Medicine,

464 Congress Avenue, Suite \#260

New Haven, CT 06519

USA

Christine.ngaruiya@yale.edu

+1 (203) 785-2353 


\begin{abstract}
Background: Non-communicable diseases (NCDs) constitute the leading cause of mortality globally. Low and middle-income countries (LMICs) not only experience the largest burden of humanitarian emergencies but are also disproportionately affected by NCDs, yet primary focus on the topic is lagging. We conducted a systematic review on the effect of humanitarian disasters on NCDs in LMICs assessing epidemiology, interventions, and treatment.
\end{abstract}

Methods: A systematic search in MEDLINE, MEDLINE (PubMed, for in-process and non-indexed citations), Social Science Citation Index, and Global Health (EBSCO) for indexed articles published before December 11, 2017 was conducted, and publications reporting on NCDs and humanitarian emergencies in LMICs were included. We extracted and synthesized results using a thematic analysis approach and present the results by disease type. The study is registered at PROSPERO (CRD42018088769).

Results: Of the 85 included publications, most reported on observational research studies and almost half (48.9\%) reported on studies in the Eastern Mediterranean Region (EMRO), with scant studies reporting on the African and Americas regions. NCDs represented a significant burden for populations affected by humanitarian crises in our findings, despite a dearth of data from particular regions and disease categories. The majority of studies included in our review presented epidemiologic evidence for the burden of disease, while few studies addressed clinical management or intervention delivery. Commonly cited barriers to healthcare access in all phases of disaster and major disease diagnoses studied included: low levels of education, financial difficulties, displacement, illiteracy, lack of access to medications, affordability of treatment and monitoring devices, and centralized healthcare infrastructure for NCDs. Screening and prevention for NCDs in disaster-prone settings was supported. Refugee status was independently identified both as a risk factor for diagnosis with an NCD and conferred worse morbidity.

Conclusions: An increased focus on the effects of, and mitigating factors for, NCDs occurring in disaster-afflicted LMICs is needed. While the majority of studies included in our review presented epidemiologic evidence for the burden of disease, research is needed to address contributing factors, interventions, and means of managing disease during humanitarian emergencies in LMICs.

\title{
Keywords:
}

NCDs; Non Communicable Diseases; Disasters; Warfare and Armed Conflicts; Cardiovascular disease; Diabetes Mellitus; Pulmonary Disease, Chronic Obstructive; Asthma; Disaster Medicine 


\section{Background}

Non-communicable diseases (NCDs) constitute the leading cause of mortality globally, accounting for $70 \%$ of deaths worldwide (1). This percentage is projected to rise in the next fifteen years, with the steepest increase in morbidity and mortality from NCDs projected to occur in Low and MiddleIncome Countries (LMICs). The World Health Organization (WHO) projects a 10\% rise in mortality in Africa from NCDs in from 2015 to 2030 (2).

The rise in NCDs in LMICs coincides with an increasing burden of humanitarian disasters (3). The International Red Cross defines a disaster as: "a sudden, calamitous event that seriously disrupts the functioning of a community or society and causes human, material, and economic or environmental losses that exceed the community's or society's ability to cope using its own resources" (4). The United Nations Office for Disaster Risk Reduction (UNISDR) recorded over 1.35 million people killed by natural hazards between 1997-2017, with disproportionate mortality in LMICs (5). Poverty, rapid urbanization, inadequate infrastructure, and underdeveloped disaster warning and health systems are all contributors to morbidity and mortality in disasters $(5,6)$. The fatalities in a disaster are most directly related to the preexisting vulnerability of the population it affects $(1,6)$.

Humanitarian response in emergencies can be divided into four phases: mitigation, preparedness, response, and recovery. Mitigation refers to measures designed to either prevent or reduce the impact of disasters. Preparedness refers to preparation and instruction to strengthen the overall capacity and capability of a country or a community for events that cannot be mitigated. The response phase encompasses the immediate aftermath of a disaster when disaster response plans are implemented. Finally, the recovery phases is comprised of restoration efforts which must occur in parallel with routine operations and activities (7). However, each phase may be prolonged, exemplified by current conflicts in Israel-Palestine, Syria, Yemen, the Democratic Republic of Congo (DRC), and countries of the Lake Chad region which are party to protracted conflicts where the response or active phase has persisted (8). Such conflicts may be international, defined as arising between two or more states, or non-international, in which one or more non-State armed groups are involved, as defined under Article 3 common to the 1949 Geneva Conventions, and may blur the line between relief and development which further necessitates attention to NCDs amongst humanitarian actors $(9,10)$.

The scale of humanitarian disasters has increased in recent decades for two primary reasons. Firstly, the frequency and ferocity of climate-related disasters are increasing due to climate changes (11). Secondly, the number of refugees, displaced persons, and migrants are at an all-time high due to the unprecedented refugee crises in Syria, Iraq, and the Democratic Republic of Congo (12). According to the UNHCR Global Trends Report, an unprecedented 79.5 million people are estimated to have been displaced from their homes as internally displaced persons (IDPs) or refugees in 2019 - the largest figure ever recorded (13). Disasters may directly exacerbate NCDs through effects such as increased stress levels (14), exposures such as inhalation of substances that trigger worsening of pulmonary disease (15), and exacerbation of underlying disease secondary to limited access to care (16).

Despite the growing burden of humanitarian crises with increasing populations at risk for morbidity and mortality from NCDs, primary focus on the topic is lagging. It is essential to better understand the effect of disasters on NCDs in LMICs as the mortality and morbidity are projected only to increase given climate change and population growth in vulnerable areas (17). In this context, we conducted a systematic review on the effect of humanitarian disasters on NCDs in LMICs assessing epidemiology, interventions, and treatment. To our knowledge, this is the first systematic review of its kind cross-cutting both regions and disease type. Our aims are to guide allocation of resources, future research, and policy development. 
medRxiv preprint doi: https://doi.org/10.1101/2020.10.15.20213025; this version posted October 20, 2020. The copyright holder for this preprint (which was not certified by peer review) is the author/funder, who has granted medRxiv a license to display the preprint in perpetuity.

All rights reserved. No reuse allowed without permission.

\section{Methods}

An experienced medical librarian performed a comprehensive search of multiple databases after consultation with the lead authors and a Medical Subject Heading (MeSH) analysis of key articles provided by the research team. In each database, we used an iterative process to translate and refine the searches. English, Arabic and French language articles were eligible and no date restrictions were applied. The formal search strategies used relevant controlled vocabulary terms and synonymous free text words and phrases to capture the concepts of noncommunicable, chronic and noninfectious diseases, and different types of humanitarian emergencies including natural disasters, armed conflicts, terrorism, and failed states (see Appendix). The databases searched were MEDLINE (OvidSP 1946-August Week 2 2015), MEDLINE (PubMed, for in-process and non-indexed citations), Social Science Citation Index, and Global Health (EBSCO). We included studies conducted in LMICs investigating noncommunicable diseases in the context of humanitarian emergencies. Studies conducted in high income countries (HICs) and review articles were excluded. No other restrictions on study type were applied. The original searches were run August 10, 2015 and were rerun on December 11,2017. The full strategy for PubMed is available in the appendix. The study is registered at PROSPERO (CRD42018088769).

Retrieved references were pooled in EndNote and de-duplicated to 4,430 citations. Two separate screeners independently evaluated the titles, abstracts and full text of the eligible articles, with vetting by a third reviewer. The flowchart per PRISMA is presented in Figure 1.

\section{Results}

We retrieved a total of 4,430 references. 4,342 studies were excluded by title or abstract, and 158 articles were read in full. Out of the studies screened, 85 were included in the final thematic analysis. We present the results by disease type. For disease type, we have five categories, which consist of the lead four NCDs in order of burden (18): cardiovascular disease (CVD), cancer, chronic respiratory disease, diabetes, and a section on other NCDs (defined as those not fitting into the lead four categories).

\section{Cardiovascular disease}

Cardiovascular disease was the most highly studied NCD after diabetes, and 29 studies addressed this (see Table 1). Syrian refugees were the most commonly studied population among studies addressing CVD (19-22). Prevalence of disease was high, as demonstrated by Sibai et al. in a community-based cross-sectional study of residents of Beirut, Lebanon with circulatory diseases accounting for nearly $60 \%$ of diagnoses, and ischemic heart disease was the leading diagnosis (20). They also demonstrated that strokes had the second highest case fatality rate (54\%), which was second only to sepsis $(60 \%)$.

Most studies assessed cardiovascular disease risk factors, or intermediate risk factors, as opposed to actual diseases such as heart attack or stroke. Intermediate risk factors as defined by the WHO are: raised blood pressure, raised glucose levels, abnormal blood lipids (particularly low density lipoprotein LDL cholesterol), overweight (body mass index(BMI) $\geq 25 \mathrm{~kg} / \mathrm{m} 2$ ), and obesity (body mass index $\geq 30$ $\mathrm{kg} / \mathrm{m} 2)(23)$. Of note, only two studies primarily addressed strokes $(24,25)$.

Hypertension remains the lead CVD risk factor $(25-27)(19,21,28,29)$, and reason for presentation for care among refugees as demonstrated by data on Iraqi refugees in Jordan, where for adults 18 and older, primary hypertension was the top diagnosis (30). However, blood pressure control remains a problem, as demonstrated among victims staying in temporary shelter more than 1 year after a 2008 earthquake in the Sichuan province of China, where only half of those diagnosed had medications (53.4\%) (27) and less than one in five (17.8\%) demonstrated control.

In a study by Marjanovic et al, conducted two years after the 1991-97 Croatia War in the Baranya region of Croatia, they found 513 stroke cases in a single-site emergency department study(24). This was one of only two studies we found that addressed strokes, providing evidence of the downstream effects of 
intermediate risk factors of high prevalence like hypertension $(24,25)$. The patients had an average age of $68.4 \mathrm{y}$, with an age range from 25-91y, and a near equal distribution of the cases between men and women (51.7\% male). Only $50.6 \%$ of patients presented within 6 hours, another $16.2 \%$ presented after 24 hours (24), paresis, speech impairment and vision impairment were the most common presenting symptoms. $38.4 \%$ died in hospital. $85.8 \%$ of patients had hypertension, $27 \%$ had diabetes, $44.6 \%$ had hyperlipidemia and $46 \%$ also had cardiac disease.

The effect of being exposed to a disaster as a primary contributor to CVD also emerged as a trend (31-37). In a Croatian study assessing the patterns of presentations for acute myocardial infarction (AMI) in 3,454 patients, they found a $23 \%$ increase (1,254 vs 1,024 hospitalized patients) as compared to the 3year period preceding the war (1989-1991), and a 15\% increase (1,173 hospitalized patients) as compared to the 3-year period following the war (1995-1998) (33). The incidence of hypertension and heart disease is also higher in those with death or injury in their family, with disease occurring most commonly within the first six months after disaster (34). In another study on residents affected by the Bosnian war, they assessed incidence of AMI and unstable angina (UA) 5 years prior to, during, and 5 years after the war (38). The overall incidence of both AMI ( $\mathrm{n}=428$ vs $365, \mathrm{p}=0.025)$ and UA $(\mathrm{n}=185$ vs $125, \mathrm{p}=0.001)$ was found to be higher during the war as compared to the period prior. In a Kuwait missile attack, Zubaid et al found that the incidence rate of AMI hospital presentations more than doubled (incidence rate ratio = 2.43; $95 \%$ CI: $1.23-4.26, \mathrm{p}<0.01$ ) for one year after the event (39). Another study assessing the effects of dust storms in western Iran, showed there was an increase in cardiovascular events with a $1.35 \%$ increase in incidence of events for every $100 \mu \mathrm{g} / \mathrm{m} 3$ increase in the PM10 concentration (particulate matter greater than $10 \mu \mathrm{m})(\mathrm{p}<0.05)(37)$. Finally, a retrospective cohort study assessing the effects of famine during the Biafran war (1967-1970) demonstrated association between undernutrition and the presence of hypertension, glucose intolerance, and overweight in Nigerian adults affected (40).

Furthermore, refugee status was associated with higher prevalence of CVD as compared to nonrefugee counterparts in several studies. Abukhdeir et al demonstrated a lower prevalence of CVD among those reporting non-refugee status in a representative sample of Palestinian households within the West Bank and the Gaza Strip (OR 0.539, p<0.001), as compared to their refugee counterparts (32). Yusef et al highlight an alarming predominance of late presentations for CVD, and other NCD risk factors, at United Nations Relief and Works Agency(UNRWA) primary health care facilities in Lebanon with $42 \%$ of respondents having at least one complication (such as retinopathy, nephropathy, and neuropathy) (22). Similarly, Kadojic demonstrated that displaced persons in Croatia residing in camps had higher prevalence of hypertension, hyperlipidemia and obesity when compared to age-matched controls in settlements not impacted by the war (25).

Regarding CVD risk factors along gender lines, generally men tend to have a higher prevalence of hypertension as compared to women, and associated CVD (myocardial infarction, congestive heart failure, and stroke) $(20,41,42)$. However, in several studies we found a trend of disproportionate prevalence and worse outcomes for women for a variety of CVD outcomes (22, 26, 29, 41, 43). Gender differences are described in a separate review.

Only one study addressed management of disease. This was a descriptive analysis by Yusef et al, showing that among refugees accessing care at UNRWA facilities in Lebanon, only 3\% were on first-line anti-hypertensive therapy, up to $14.2 \%$ were on third line treatment, and $10 \%$ reported lifestyle modifications (22). Another study discussed a complex intervention that included capacity-building of staff, provision of key diagnostic tools such as blood pressure cuffs, stethoscopes and glucometers), and advocacy on providing NCD care. The intervention took place in Lebanon (19), and they implemented screening for DM and hypertension in those $40 \mathrm{y}$ and older attending any of the clinics (five health centers and three mobile units), with the potential for referral to a specialist, such as cardiology, in case of need. 
This and the scant other interventions found in our study $(19,44-48,123)$ are further addressed in a separate publication.

\section{Cancer}

Multiple studies demonstrated that cancer and oncological emergencies affect populations in conflict (see Table 2). Of the articles, there was a predominant geographic focus on the EMRO region. In Lebanon, Sibai et al (20) observed that cancer was second only to cardiac disease as a cause of death. Cancer represented $15 \%$ of all causes of deaths in their retrospective cohort study of 1,567 Lebanese aged 50 years and over residing in Beirut during the Lebanese Civil War (1975-1990). This was followed postwar by Shamseddine et al (49) who identified an overall crude incidence rate for all cancers combined of 141.4 per 100,000 among males and 126.8 among females, a sharp contrast to earlier estimates made in 1966, of 102.8 and 104.1, respectively (49). Of note, few studies addressed refugees, Internally Displaced Persons (IDPs) or noncombatants, in particular $(20,49)$. We identified no articles relating to cancer prevalence among refugees in Africa, Asia, or the Americas. No studies addressed palliative care for oncology patients in the disaster setting.

Multiple studies indicate a high prevalence of modifiable cancer risk factors (49-52) in conflictaffected populations that could be targets for future intervention such as Human papillomavirus (HPV) vaccination, anti-tobacco smoking campaigns, and access to adequate nutrient-rich food. Cervical cancer, in particular, was identified as being related to or affected by war $(51,53)$. For example, in the study by Huynh et al (53), they demonstrate that southern Vietnamese women whose husbands served in the armed forces experienced a more than $160 \%-290 \%$ increase in cervical cancer risk, relative to women whose husbands had not served in the armed forces. The authors attribute the association between male combat activity and cervical cancer as men become reservoirs of high risk subtypes of HPV which cause cervical cancer, acquired during wartime movement patterns $(53,54)$.

We also found a variety of tobacco-related cancers, which highlights the importance of tobacco cessation. Shamseddine et al (49), found, in reviewing 4,388 new cancer cases in post-civil war Lebanon, that lung cancer was the third most prevalent cancer type. In addition, they highlight that bladder cancer incidence rates are disproportionately higher in Lebanon than in the region, and globally. Breast cancer was listed by multiple studies as the most significant cancer burden amongst women in conflict affected LMICs - including studies relating to Lebanon (49), Afghanistan (55), and Pakistan (55) - demonstrating a clear need amongst refugees for accessible mammography. Tobacco associated cancers were noted as prominent in multiple conflict affected nations and as amenable to prevention efforts through antismoking campaigns $(49,55)$.

Li et al (50) identified a relationship between sustained malnutrition in early life and an increased risk of stomach cancer mortality in later life for survivors of the 1959-1961 Chinese famine. Birth cohorts of Zhaoyuan County, China who were exposed to famine or experienced malnutrition had higher stomach cancer mortality rates 15 to 20 years post-famine as compared to birth cohorts not exposed to malnutrition (50). Proposed mechanisms by the authors for this relationship include a correlation between nutritional deficiency and $\mathrm{H}$. Pylori infection, consumption of foods associated with development of gastric carcinoma in times of famine such as salted meat containing N-nitrosamines or nitrite, vitamin deficiencies, and heavy alcohol use (50).

Relating specifically to refugees, Otoukesh et al (42), provided cancer prevalence data for refugees in a 2012 retrospective cross-sectional study of Afghani refugees residing in Iran. Using demographic and medical data collected between 2005 and 2010 from referrals to the United Nations High Commissioner for Refugees (UNHCR) offices in Iran for Afghani refugees, they found that neoplasms represented $13.3 \%$ of all referrals second only to ophthalmic diseases. Likewise, McKenzie et al (48) found that amongst UNHCR registered Iraqi and Syrian refugees in Jordan, brain tumors accounted for $13 \%$ of all neuropsychiatric applications. Furthermore, Khan et al found a divergence in the epidemiology of cancer diagnosis from the host population when compared to refugees, with esophageal cancer representing $16.6 \%$ of oncological cases amongst male Afghan refugees compared to only $4.6 \%$ of 
cases amongst Pakistani residents(55), and further evidence shows a difference in breakdown by ethnicity exemplified by Pashtun refugees who experienced a disproportionate frequency of referrals for oncologic disease(17\%) amongst Afghani refugees residing in Iran despite receiving only two percent of all referrals (42).

Further studies identified challenges specific to refugee populations or subgroups of refugee populations $(42,45,51,53,55)$. Marom et al (45) described clinical and ethical dilemmas in patients with head and neck cancers presenting to a joint Israeli-Filipino field hospital during the subacute period following a 2013 typhoon in the Philippines. They highlight the importance of awareness of cancer epidemiology in the target country prior to deployment. In this case, it guided the Israeli team's clinical management such as prioritizing physical examination for cervical nodal metastases based on known prevalence of regional lymph node involvement at presentation in $70 \%$ of Filipinos with head and neck cancers (45).

Cost of care as a barrier for refugees with cancers was studied by McKenzie et al (48) who aimed to assess the prevalence and cost of neuropsychiatric disorders among Syrian and Iraqi refugees requiring advanced specialty care in Jordan. The UNHCR funds tertiary level medical care for refugees based on the cost and acuity of required care by means of application to an Exceptional Care Committee (ECC). In reviewing refugee applications for tertiary care to the ECC, McKenzie et al (48) found that brain tumors represented the most expensive neuropsychiatric diagnosis overall (\$181,815 USD, \$7,905 USD/ applicant). Other referral diagnoses were stroke, psychiatric diagnoses, trauma, infectious diseases, multiple sclerosis, neurodevelopmental abnormalities, and epilepsy.

\section{Chronic Respiratory Disease}

Of the fourteen articles that addressed chronic respiratory disease, six were related to war, and most addressed health hazards faced by refugees or victims of chemical weaponry (see Table 3 ). The geographic focus of most of these studies was the Middle East, with six studies from Iran alone.

Two studies conducted in Kuwaiti patients affected by the Gulf War demonstrated the association between war trauma and increased in incidence of asthma exacerbations. However, despite the increase in frequency, there was no change in severity of exacerbations. One study found increasing levels of selfreported stress exposure were correlated with reports of asthma (56). In contrast, a chart review on patients admitted with asthma in Kuwait found no difference in admission or mortality rates from asthma when comparing the pre-war and post-war periods (57).

Chemical agents used during warfare, such as sulfur mustard gas, confer an additional risk for chronic respiratory disease (58). In one study assessing incidence of asthma among children of individuals exposed to chemical warfare, a similar incidence of disease was found to that of individuals born to parents with asthma (59). The comparable incidence is concerning for chemical warfare as an independent contributor to the development of asthma. Additionally, a cross-sectional study of a Chronic Obstructive Pulmonary Disease (COPD) cohort demonstrated increased morbidity of patients exposed to sulfur mustard gas also conducted in Iran, and validated use of the COPD Assessment Tool (CAT) for quality of life in this population (60).

The effect of storms on respiratory illness was also studied $(37,61)$. The only prospective observational study within our review on chronic respiratory disease was on this topic, evaluating asthma exacerbations and bronchospasm associated with thunderstorms in southwestern part of Iran, Ahvaz (61). Two thousand patients who presented with these complaints within three weeks of a thunderstorm were surveyed. This represented an abnormal surge in such complaints for emergency departments there. $30 \%$ of patients reported developing their symptoms on the day of the thunderstorm, although only $2 \%$ presented within 24 hours. At 3 weeks follow-up, more than two thirds were still using medications, with beta-agonists being the most likely prescriptions, and corticosteroids following. More than half (51.7\%) had no prior history of respiratory disease or complaints of shortness of breath. A retrospective chart review similarly looked at respiratory illness and evaluated correlation with dust storms (37). In contrast, 
this study concluded that cardiac $(\mathrm{P}<0.05)$, but not respiratory, disease was associated with occurrence of dust storms.

Beyond storms, a variety of studies looked at the health effects of different types of natural disasters via chart review of patients who presented after the disaster. A large forest fire in Indonesia caused a "haze disaster" in 1997 resulting in increased respiratory complaints. Among 543 respondents, while only $7.4 \%$ had a history of chronic respiratory illness (asthma), $98.7 \%$ presented with respiratory complaints. $49.2 \%$ of all respondents reported symptoms which disturbed their daily life (62). In Ecuador, researchers looked at pediatric emergency department visits and found that there was an increase in frequency of visits associated with volcanic eruptions. Visits for asthma and asthma-related conditions doubled (RR 1.97, 95\% CI 1.19, 3.24) during the three weeks following volcanic activity (63). Among NCD presentations to an International Committee of the Red Cross (ICRC) Hospital in Banda Aceh, Indonesia post-tsunami respiratory diseases were one of the most commonly recorded conditions (21\%), which included acute asthma exacerbations (64). Similarly, Redwood-Campbell et al (65) cited respiratory complaints as constituting $12 \%$ of presentations in the outpatient/ emergency department at the same Indonesian ICRC facility, with asthma making up $29 \%$ of those cases.

Studies looking at populations in refugee camps were epidemiologic in nature. In the Palestinian West Bank, children from refugee camps were at higher risk of asthma than children from neighboring villages or cities (66). Having a history of wheezing was reported for $22.1 \%$ of children in refugee camps versus $16.5 \%$ in cities, and $15.5 \%$ in villages. Overall, $8.8 \%(n=298)$ of children reported wheezing in the previous year, with a $17.1 \%$ lifetime prevalence of wheezing. Similarly, in the slums of Dhaka, Bangladesh, children under 5 who were part of a "climate refugee" community were studied and compared to a non-refugee group. Asthma caused a 1069-fold higher number of disability adjusted life years (DALYs) lost in the group displaced due to climate change in comparison to non-affected populations (67).

\section{Diabetes}

We found that studies addressing diabetes were predominantly conducted in the EMRO Region (see Table 4). Specifically, 20 studies were conducted in the Eastern Mediterranean Region, two studies were conducted in the Caucasus region, three studies occurred in Sub-Saharan Africa, six studies occurred in Asia including South and Southeast Asia, and two studies were conducted in Eastern Europe.

Multiple studies point to the relationship between stress and personal loss incurred in natural disasters and conflict, and a subsequent rise in occurrences of impaired fasting glucose (IFG) and diabetes mellitus (DM) among survivors (34, 47, 68-70). One such retrospective cohort study by An et al. (68) investigated the long-term impact of stresses from the 1976 Tangshan earthquake on the occurrences of impaired IFG and DM among survivors and found that the incidences of IFG and DM for the exposure groups were significantly higher than that for the control group $(\mathrm{P}=0.043$ for IFG; $\mathrm{P}=0.042$ for diabetes), with those who had lost relatives exhibiting a higher diabetes incidence than those who had not lost relatives. This effect was only statistically significant in women earthquake survivors ( $p=0.009$ ) (68). In addition, refugees with diabetes were found to have strongly reduced quality of life (HRQOL) as compared to age-matched non-diabetic controls as identified by Eljedi et al. using the World Health Organization Quality of Life questionnaire (WHOQOL-BREF), with particularly severe effects noted among females ( $\mathrm{p}<0.05$ in all four domains) (71).

Additionally, several studies addressed food insecurity, and identified it as a primary contributing factor affecting diabetes management $(21,29,47,72)$. A study focusing on older Palestinian refugees (21) found that participants practiced reduced meal portion sizes, skipping a meal, or foregoing a full day's meals due to food shortage at a significantly higher rate than an age matched host population in Syria (reducing portion sizes $\mathrm{p}<0.001$; skipping a meal $\mathrm{p}<0.001$; not eating at all $\mathrm{p}<0.001$ ). Factors associated 
with skipped meals or reduced portion sizes included low economic status, larger household size, and type of residence (financial status $\mathrm{p}=0.009$; household size $\mathrm{p}<0.001$; type of residence $\mathrm{p}<0.001$ ). The number of days older refugees reported eating only bread and nothing else corresponded to reported financial status $(\mathrm{p}=0.036)$. The authors theorized that food insecurity may result in challenges in the management of diabetes.

Further studies specifically addressed effects of fetal exposure to malnutrition and impaired glucose tolerance or diabetes later in life (40,73-75). Hult et al. (40) examined the accumulated risk for glucose intolerance 40 years following fetal exposure to famine in Biafra, Nigeria during the Nigerian civil war. The crude odds ratios for both impaired glucose tolerance and diabetes diagnoses were significantly higher for the group exposed to fetal or infant famine in comparison to controls (40). Consistent findings were identified by a retrospective cohort study from China by Li et al. (73), who also identified a relationship between the severity of famine for fetal exposed subjects and risk of hyperglycemia later in life $(\mathrm{OR}=3.92 ; 95 \%$ CI: $1.64-9.39 ; P=0.002)$. Similarly, in a region of Northern Ethiopia recently affected by severe famine, clinical features of 100 insulin-treated diabetic patients were consistent with previous descriptions of malnutrition-related diabetes mellitus (MRDM): young age of onset $(70 \%$ < 30 yrs), low BMI(mean 15.8), and resistance to ketosis (only 4\% admitted with diabetic ketoacidosis despite $48 \%$ reporting insulin treatment interruption) (75).

Additional barriers to glycemic control in patients affected by conflict were: migration after war, lack of self-monitoring glucose strips, lack of access and cost of medications, failure to adequately screen for diabetes, inability to travel to a heath facility, lack of education regarding diabetes complications and management, food availability, and difficulty following patients over time $(21,22,29,41,44,47,75-81)$. One cross sectional study (76) which aimed to identify barriers to glycemic control from the patient perspective in a diabetic clinic in the south of Iraq, found that lack of drug supply from a primary health care center or drug shortage is a barrier for $50.8 \%$ of patients, while drug and/or laboratory expenses were a barrier for $50.2 \%$ of patients. $30.7 \%$ of patients said that they were not aware of possible diabetic complications and 30\% thought that their failure to control their diabetes was due to migration after the war. Lack of electricity, lack of access to blood glucose monitoring devices, and illiteracy as a cause were cited by $15 \%, 10.8 \%$ and $9.9 \%$ respectively (76). In Mali and Ethiopia, insulin was not widely available and access was limited by cost (US\$ 11 per vial in Mali)(44, 75). Multiple studies noted that syringes and self-monitoring blood glucose devices were not readily available and posed a financial burden to those who required access to them $(44,75,77)$.

One study investigated complementary and alternative medicine (CAM) use among Palestinian diabetic patients and found the use of CAM differed significantly between residents of refugee camps as compared to residents of urban or rural areas $(\mathrm{p}=0.034)(82)$. Those who were on CAM reported they were using it to slow down the progression of disease or relieve symptoms and $68 \%$ of patients interviewed reported not disclosing CAM use to their physician or pharmacist.

While no study specifically aimed to focus on gender in their primary research objectives, we found a relationship between gender and prevalence or access to resources for diabetes, emerged as a recurring theme $(22,32,68,70,71,75,83)$. These findings will be presented in a separate publication. Other common risk factors associated with diabetes type 2 included age, having a higher BMI, being divorced/widowed/separated, having never attended school, illiteracy, comorbid hypertension, hyperlipidemia, family history, sedentary lifestyle, history of traumatic exposure, and refugee status (21, 22, 29, 32, 69, 83, 84).

Several studies also took a health systems approach and found that reliance on tertiary care for diabetes management fostered unequal access by socioeconomic status, geographic location, and escalating healthcare costs overall $(44,77,85,86)$. One study from Georgia (77), which sought to identify the extent to which the Georgian health system provides for effective diabetes control postindependence, identified a systems level concern that only tertiary-level endocrinologists were able to modify treatment regimens and prescribe insulin whereas even endocrinologists who worked in polyclinics were unable to determine insulin regimens or prescribe insulin. Three studies from Syria (85), 
medRxiv preprint doi: https://doi.org/10.1101/2020.10.15.20213025; this version posted October 20, 2020. The copyright holder for this preprint (which was not certified by peer review) is the author/funder, who has granted medRxiv a license to display the preprint in perpetuity.

All rights reserved. No reuse allowed without permission.

Tunisia(86), and Mali (44) identified a similar shift of diabetes care to the tertiary level prior to the emergence of conflict in these countries due to an emerging private sector $(85,86)$ and lack of specialists(44), respectively. In Mali, the lack of specialists was augmented by a lack of available guidelines, treatment protocols, and training for primary care level providers which prevented a transition of care to primary or general practitioners(44). The authors theorized that this shift of diabetes care to the tertiary level contributed to reduced care access during active conflict in these countries $(44,85,86)$.

\section{Other NCDs}

Studies investigating other NCDs centered on musculoskeletal and joint disorders $(26,30,34,65)$ epilepsy and other neuropsychiatric disorders $(42,48,87)$, ophthalmic diseases $(30,42,88)$, nephropathies and urologic complaints $(30,42,65)$ (see Table 5). Two studies measured mortality rates $(20,34)$ and two also studied quality of life $(89,90)$. The effects of disability were briefly touched on by Leeuw et al (90), with Amini et al (89) further identifying hearing loss, and tinnitus as having negative impacts on quality of life among blind survivors from the Iranian War $(\mathrm{p}=0.005, \mathrm{p}<0.0001)$ as compared to non-afflicted counterparts. We found that the majority of the studies on other NCDs did not refer to specific diseases or illnesses $(26,30,65,91)$, but rather represented epidemiological studies referring to conditions more broadly such as in the case of Mateen et al (30) referring to "joint disorders", and Hung and Redwood-Campbell describing "musculoskeletal", "respiratory complaints," and "gastrointestinal complaints" of unclear etiology $(26,65)$.

Hung et al described musculoskeletal complaints constituting $30.4 \%$ of presentations among those visiting a Hong Kong Red Cross clinic in rural China following the 2008 Sichuan earthquake (26). Mateen et al. conducted a far-reaching study of refugees in 127 camp settings across 19 countries and found that reportable neurologic diseases accounted for 59,598 visits over a 4-year period (87). Nearly $90 \%$ of these cases were for epilepsy, which they highlight far outweighed the prevalence of neurological diagnoses of an infectious nature. Another study investigated neuropsychiatric disorders among Syrian and Iraqi refugees in Jordan via retrospective review of applications to the Jordanian Exceptional Care Committee, and found stroke to be the most common neuropsychiatric diagnosis ( $n=41$ applications, $16 \%$ of neuropsychiatric applications; median age 64 years) (48).

Specific ophthalmic diseases identified by Mateen et al include cataracts (1.44 visits per refugee) and glaucoma (1.46 visits per refugee), which were exceeded only by cerebrovascular disease (1.46 visits per refugee) among Iraqi refugees in Jordan (30). Of note, more than half of the refugees received concomitant diagnoses in one visit. Otoukesh describes ophthalmic disease as the most common health referral (13.65\%) for those aged 15-59 among Afghan refugees in Iran(42). Amini et al(89) measured Quality of Life (QOL) scores in Iranian survivors totally blinded during the Iran-Iraq War, the effects of which were mitigated among those with higher levels of education $(\mathrm{p}=0.006)$. Urologic complaints were identified as predominant in the ICRC hospital in Banda Aceh, Indonesia with 19\% of complaints(65); specific examples of urologic disorders from Mateen et al among Iraqi refugees constituting a significant amount of morbidity were prostatic hypertrophy and nephrolithiasis(30). Hematologic disorders were described by Otoukesh, and the type of disorder varied by ethnicity, with referrals for the Baluch being the highest at $25 \%$ (42).

\section{Concomitant affliction with NCDs}

Finally, co-affliction with multiple NCDs was a recurrent issue in our findings. This was demonstrated by Strong et al among Palestinian refugees in Lebanon, with an average of 4 NCDs per person; Syrian refugees in the same study had an average of 2.5 NCDs per person (21). Three or more risk factors were also seen in displaced persons in Croatia, a statistically significant difference in prevalence when compared to age-matched controls who were not displaced (25). Clustering of risk 
factors was also evident in a populations being served by UNRWA in Jordan, Syria, Lebanon, West Bank, and the Gaza Strip, and the risk of having CVD was 2.7 times higher in individuals with 4 risk factors as compared to those with only 1 risk factor (29). Concomitant affliction also conferred worse outcomes among Palestine refugees in Jordan with CVD (myocardial infarction, congestive heart failure, stroke and blindness) among those with hypertension and diabetes, when compared to those with hypertension alone in the same cohort $(\mathrm{p}<0.01)(41)$. Yusef et al also demonstrated that having concomitant risk factors (such as diabetes and hypertension) resulted in a higher likelihood of presentation with late complications of NCDs at a UNRWA primary healthcare field site in Lebanon (22).

\section{Discussion}

NCDs represented a significant burden for populations affected by humanitarian crises and natural disasters for all regions $(20,39,42,44,45,48,49,53,67,92-94,124)$, and even conferred increased mortality and morbidity when compared to infectious diseases in one study (95). Individuals with NCDs may present for continued management of chronic conditions or with an acute exacerbation of a chronic NCD triggered by the acute disaster state $(64,65)$. Furthermore, several studies demonstrated that NCDs adversely affected morbidity of populations in humanitarian crises with women and older populations disproportionately affected $(60,71,89,96)$. Late stage complications of cardiovascular diseases and diabetes including stroke $(24,48,78,87,95)$, diabetic foot amputations $(22,46,78,94)$, and myocardial infarctions $(31,39)$ were described in all regions $(22,78)$. However, pulmonary diseases such as asthma, COPD and lung cancer were noticeably lacking. Similarly, scant studies focused on pediatric populations $(59,63,66,67)$. Strengthening and broadening the spectrum of NCD diagnoses included in disaster management planning is key, and particular focus on children and adolescents is critical as these age groups present key opportunities for interventions to mitigate future NCD morbidity $(97,98)$. Finally, several studies identified challenges and epidemiologic factors specific to refugee populations or subgroups of refugee populations $(42,45,51,53,55)$, and they also highlight that refugee populations are heterogenous in their disease burden. Understanding these populations is key in guiding the medical equipment, personnel including specialists, and potential screening programs that should be considered in future humanitarian efforts.

\section{Disparities in evidence by region}

There is little information $(19,44,94)$ for all regions and disease categories about the experience of the affected population during acute crises, active conflict, or as internally displaced persons (IDPs) $(42,45,48,53,55)$ (see Tables 8-10). As far as regional focus of studies assessed, both Sub-Saharan Africa and the Americas were poorly represented in the literature on NCDs in humanitarian crises (40, 44, 75, 95) (see Tables 6-7). This is in spite of the fact that these regions experience a marked dual burden of armed conflict $(99,100)$ and natural disasters $(101,102)$, and represent a significant portion of the global NCD burden (103, 104). 32.4\%

In Asia, the Western Pacific, and the Americas there was a specific focus on natural disasters (63, 64), whereas the Eastern Mediterranean Region (EMRO) and Africa regions focused primarily on armed conflict $(39,44,94,95)$. Of note, most studies either reported on the consequences of conflict after the fact (95) or when the population of interest had relocated to a refugee camp or host country $(42,48,55$, $81)$.

Certain regions or populations were more heavily studied than others as was the case for DM where $57.6 \%$ of studies reviewed were conducted in the EMRO region. $32.4 \%$ of DM studies focused on the Palestinian $(22,29,32,71,78-82,84,105)$ population alone, higher than Africa, the Americas, Western Pacific (WP), and South East Asia (SEA) combined. The high prevalence of articles conducted in the EMRO may reflect the higher prevalence of diabetes there (106). However, with a rise of diabetes in all regions including Sub-Saharan Africa, where the largest percentage increase in the incidence of diabetes is projected in the coming decade, this represents a significant gap in the available literature (107). 
Increased research is needed on NCDs in multiple settings, particularly outside of the EMRO region, and better understanding of the effects of diverse crises, rather than just armed conflict is also key. The effects of climate change (11), and subsequent increasing natural disasters, highlight our need to identify NCD burden in order to guide appropriate responses during these events.

\section{Methodology}

The predominant study design consisted of retrospective chart reviews with a minority of crosssectional studies $(42,49,52,55)$. We observed that several studies either did not include a comparison group in their study design, or they used a time period across which the comparison was made that was arbitrary in nature. While challenging to conduct given the context of the studies, this limits validity of findings in many studies $(42,45,48,53,55)$. In addition, it was noted that publications were clustered by research group or author $(31,41,73,78-81,108,109)$, which speaks to the need for increased academic outputs in LMICs, and Africa in particular. Finally, several articles that were included in our results included NCDs as a peripheral focus, rather than as primary outcomes $(65,110)$. There is a need to prioritize NCDs in humanitarian crises, assessing both epidemiology, but also effective interventions to target disease. Consideration should be given to include comparison or control groups in study design, for example individuals in neighboring regions, non-refugee counterparts, or matched sample populations not afflicted by the disease $(34,53)$ to be able to better assess and thus target the effects of the humanitarian crises itself on disease outcomes. Additionally, long-term cohorts and registries (105) would be ideal to better understand the diversity of diseases and contributory factors in even greater depth. Of all the studies included, none referred to the Sphere guidelines(111), WHO Noncommunicable Diseases in Emergencies brief (112), or WHO PEN package of essential NCD interventions(113) as markers for study design, which we propose be included in future research.

\section{Concomitant affliction with NCDs and NCD risk factors}

We found that the populations studied were commonly afflicted with multiple NCD risk factors $(21,29,32)$ and multiple NCDs $(21,22,29,41)$, which supports the need for consolidated care for NCDs as co-affliction confers higher risk of complications (22). Many commonly cited risk factors in HICs such as age, family history, higher BMI, comorbid hypertension, smoking, hyperlipidemia, family history, sedentary lifestyle for DM, cancer, cardiovascular disease were cited $(21,22,29,32,49,69,83,84)$. However, a lack of association between NCDs and family history as well as other traditional risk factors was also found, and this may result in under-recognition and subsequent under-diagnosis in these settings $(93,110)$. Greater attention to screening and allocation of resources are needed in disaster-prone settings to prepare, in addition to medical relief efforts deployed during crises specifically prepared to address NCD care.

\section{Barriers to NCD care}

The most commonly cited barriers to healthcare access in all phases of disasters and major disease diagnoses studied, included personal attributes: low levels of education $(75,76,114)$, financial difficulties $(21,76,92)$, displacement $(44,76)$, and illiteracy $(29,32,76)$. The most commonly cited systems level concerns were lack of access to medications, and affordability of medications $(21,22,44$, 76, 115). Multiple DM specific studies noted that syringes and self-monitoring blood glucose devices were not readily available and posed a financial burden to those who required access to them $(44,75,77)$. Several studies also noted shifting of medications from the clinically indicated medication to cheaper or more available options, which may lead to worse outcomes $(22,77)$. Such challenges may be magnified more for migratory refugees as compared to those who are more established in refugee camps, as demonstrated by Yusef et al (22).

Greater attention to screening and allocation of resources to treat NCDs including acute cardiovascular events such as acute myocardial infarction and stroke are needed in disaster-prone settings, outside of other medical relief efforts. This should include palliative interventions that aim to reduce 
excess morbidity and suffering from NCDs (116). A health system situational analysis in Tunisia demonstrates the effectiveness of a robustly developing primary health care system, which falls short in this setting without sufficient human resources, reimbursement for public sector, consensus around guidelines for management, and the absence of ancillary providers such as nutritionists or specialists for referral, when needed (86). In post-war Liberia, with majority of CVD deaths occurring within 24 hours of admission, optimization of emergency care which is the first point of contact, was also highlighted (95). Hung et al, the only researchers focusing on the pre-hospital setting, also enforce the importance of raising awareness among first responders of the associated increased burden of NCDs during crisis and propose guidelines adapted to this (26). Finally, decentralization of care to community-based settings, such as for eye care, was presented (30).

\section{Disaster related stressors and NCD development and morbidity}

Multiple studies identified disaster-related psychologic and physical stressors as significant risk factors for NCDs $(25,35,40,47,51,52,56,68-70,73,74)$, as well as described subsequent increased NCD related morbidity as a result of disaster stressors $(25,34,36,38,39,56,72,94)$. Bereavement, injuries in the family $(34,38,68)$, displacement (92), temporal/ geographical proximity $(32,36,39,72)$, and war-related physical and psychological trauma $(34,56,70)$ were some of the independent predictors of diagnosis, and increased NCD morbidity $(34,35,38,39,56,68)$. Refugee status was independently identified both as a risk factor for diagnosis with an $\operatorname{NCD}(25,29,32,47,66)$, and conferring worse morbidity as indicated by Disability Adjusted Life Years (DALYs) lost (67).

Malnutrition and food insecurity during disaster were commonly cited risk factors for increased NCD morbidity. Notably, fetal exposure to severe famine was associated with an increased risk of cancer (117), DM/impaired glucose tolerance (40,73-75), metabolic syndrome later in life (109), and the unique phenomenon of Malnutrition Related Diabetes Mellitus (MRDM) (75). The risk of MRDM was exacerbated by a nutritionally rich environment later in life $(74,118)$. Another hypothesis for the higher prevalence of DM was lack of ability to monitor and control dietary intake and blood sugar during a crisis $(21,29,47,72)$.

Finally, environmental exposures from natural disasters (26, 37, 61-63) and war related toxins $(58,59,88)$ contribute to NCD burden for these populations particularly for respiratory and cardiovascular diseases. Natural disasters impacting chronic respiratory illness include thunderstorms, earthquakes, forest fires, volcanic eruptions, and tsunami. Dust storms were a notable exception in one study (37), for which a link to increased pulmonary illness was not shown, while in contrast there was evidence of an effect on cardiovascular disease.

In sum, disaster settings confer higher incidence of NCDs and associated comorbidity Furthermore, attention to refugee status in disaster settings is key given a disparate disease burden. Refugee populations have greater burden of disease and worsened outcomes when compared to host populations. Distribution of disease within a refugee population may be unique, and further divergent by ethnic group even among refugee populations. This is critical information for humanitarian intervention design and implementation.

\section{Lack of infrastructure for NCDs confers poorer responsiveness during crisis}

In many countries affected by humanitarian emergencies, there is scarce data on NCD surveillance, epidemiology, and outcomes in populations at risk in the pre-disaster setting, which creates challenges for disaster mitigation efforts $(91,93)$. Moreover, poorly functioning systems for delivery of NCD care $(44,85)$, and underdiagnosis of $\operatorname{NCDs}(93,110)$ in the pre-disaster setting are compounded by new challenges resulting from widespread destruction of the health system (119). Centralized care of NCDs in tertiary health facilities pre-disaster was commonly noted to hinder NCD care access during the relief phase and integration of NCD care into the health system at all levels was supported. $(44,65,85$, 86). Several diseases including leading cancer diagnoses are amenable to prevention, screening, and early detection such as breast cancer $(49,55)$, cervical cancer $(51,53)$, and other cancers associated with 
tobacco use $(49,55)$. Cervical cancer, for example, is amenable both to primary prevention strategies (HPV immunization and barrier protection during sexual intercourse) as well as secondary prevention (pap smears), and was identified as an opportunity for targeting by several studies with high prevalence including in Vietnam (53) and Croatia (51). Decentralization of primary care provision to communitybased settings, such as for eye care, was advocated to address the loss of healthcare infrastructure (65), and may reduce stress on facilities providing emergent care $(30,65)$. Reinforcement of the public health sector's capacity for NCD management benefits both the relief phase of disaster response as well as well as post-disaster rehabilitation and reconstruction (119). Overall, increased preparedness $(44,46,77,85)$ and responsiveness by aid providers, health providers, and local governments to NCDs in disasters (44, 46) would help improve disaster mitigation assessments. Validated tools such as the WHO Stepwise approach to Surveillance (120) or Demographic Health Surveys(121) could be used for surveillance or to develop registries in countries.

\section{Conclusion}

An increased focus on the effects of, and mitigating factors for, NCDs occurring in disasterafflicted LMICs is direly needed. While majority of studies included in our review presented epidemiologic evidence for the burden of disease, research is needed to address contributing factors, and means of managing disease in these extremely resource-variable settings. Regions particularly lacking evidence on LMICs in our study were Africa and the Americas; majority of evidence was from the EMRO region. Among the four lead NCDs, chronic respiratory disease was under-addressed despite evidence that it contributes to high morbidity in crisis. Furthermore, increased evidence on actual diseases such as myocardial infarction and diabetes, rather than simply focusing on risk factors such as hypertension is also needed. Attention to vulnerable populations including women and refugees is also a priority. Refugees have unique exposures that may predispose them to certain illnesses, such as MRDM, and management needs that warrant separate attention from host populations. Given this, we propose that refugee status be considered as an independent risk factor for future studies and interventions. We found only scant interventions designed to address NCDs, which will be presented elsewhere. All in all, screening and prevention for NCDs should be a priority alongside communicable disease programs, such as counseling for smoking cessation, counseling on diet, HPV vaccination, and screening for common cancers like breast and cervical cancer. Studies on implementation for these and other interventions will be key. Additionally, equipping health systems to address NCDs both pre-disaster and during the crisis will enhance these efforts, as well as decentralization of care from tertiary settings that are already overextended during crisis. Finally, the need to address disease in collaboration with other sectors such as agriculture, and urban policy-makers, rather than working in silos, was also supported.

\section{Declarations}

Ethics approval and consent to participate

Not applicable.

Consent for publication

Not applicable.

Availability of data and materials

All data generated or analyzed during this study are included in this published article and its

supplementary information files. The study is registered at PROSPERO (CRD42018088769).

\section{Competing interests}

The authors declare that they have no competing interests. 
medRxiv preprint doi: https://doi.org/10.1101/2020.10.15.20213025; this version posted October 20, 2020. The copyright holder for this preprint (which was not certified by peer review) is the author/funder, who has granted medRxiv a license to display the preprint in perpetuity.

All rights reserved. No reuse allowed without permission.

\section{Funding}

The authors received no specific funding for this work.

Authors' contributions

CN conceptualized the study, developed the study protocol, led the screening and data extraction processes, and was a major contributor in writing the manuscript. RB conceptualized the study, carried out the literature search and data extraction, and contributed to writing the manuscript. RL conceptualized the study, carried out the data extraction, and was a major contributor in writing the manuscript. DH developed the study protocol and the literature search process, and contributed to writing the manuscript. LW assisted with screening and data extraction. PA and AS contributed to data extraction and contributed to writing the manuscript. AH contributed to study conceptualization, oversaw study protocol development, and contributed to writing the manuscript. All authors read and approved the final manuscript.

\section{Acknowledgements}

Not applicable.

\section{Authors' information}

$\mathrm{CN}$ is an Assistant Professor in the Section of Global Health and International Emergency Medicine in the Department of Emergency Medicine at Yale University. Her research centers on: Non-communicable Diseases (NCDs), barriers to care, and intervention development with a particular focus on East Africa. Her past work includes developing a health linkage to care program for refugees in the lead resettlement state per capita in the US (NE), and serving on the board of the leading refugee resettlement agency in CT. RB holds an MPH in Chronic Disease Epidemiology and has conducted a variety of research projects understanding health impacts of humanitarian emergencies. She is currently a PHI/CDC Surveillance Fellow working at the CDC Zambia country office. RL is a medical student at Ben Gurion University in Beer Sheva, Israel and affiliate researcher in the Department of Emergency Medicine at Yale University, with over seven years of fieldwork with organizations supporting refugee health provision and human rights work, including but not limited to Physicians for Human Rights-Israel, Save a Child's Heart, the Physicians for Human Rights Student Advisory Board (PHR SAB), and the Integrated Refugee and Immigrant Services(IRIS). PA is the director of Global Health Education in the Department of Emergency Medicine at Yale University, on the Research Committee for the Society for North American Refugee Health Providers, and the President of the Academy for Women in Academic Emergency Medicine, with a specific research focus on refugees and other displaced populations. AS is an Assistant Professor Adjunct of Emergency Medicine at Yale University School of Medicine, having completed the Global Health and International Emergency Medicine Fellowship at Yale University and a Master's degree in Tropical Medicine \& International Health at the London School of Hygiene and Tropical Medicine, and also currently serves as senior editor for the Global Emergency Medicine Literature Review (GEMLR) group. DH has been a medical librarian for 17 years and has experience developing robust and reproduceable search strategies for systematic reviews. AH is an Assistant Professor in the divisions of Education and Global Health in the Department of Emergency Medicine at Brown University and is fellowship trained in disaster medicine and emergency management. She served as co-founder and director for the Uganda Village Project in rural eastern Uganda for 10 years, overseeing public health programs including malaria prevention, family planning, water, sanitation and hygiene. 
List of Abbreviations

AMI: Acute Myocardial Infarction

BMI: Body Mass Index

CAT: COPD Assessment Tool

COPD: Chronic Obstructive Pulmonary Disease CVD: Cardiovascular Disease

DALYs: Disability Adjusted Life Years

DM: Diabetes Mellitus

ECC: Exceptional Care Committee

EMRO: Eastern Mediterranean Region

HICs: High Income Countries

HPV: Human Papillomavirus

HRQOL: Health-Related Quality of Life

HTN: Hypertension

ICRC: International Committee of the Red Cross

IFG: Impaired Fasting Glucose

LDL: Low Density Lipoprotein

LMICs: Low and Middle-Income Countries

NCDs: Non-Communicable Diseases

MRDM: Malnutrition Related Diabetes Mellitus

MeSH: Medical Subject Heading

NGOs: Non-Governmental Organisations

OR: Odds Ratio

SEA: South East Asia

UNHCR: United Nations High Commissioner for Refugees

UNISDR: United Nations Office for Disaster Risk Reduction

UNRWA: United Nations Relief and Works Agency 
medRxiv preprint doi: https://doi.org/10.1101/2020.10.15.20213025; this version posted October 20, 2020. The copyright holder for this preprint

(which was not certified by peer review) is the author/funder, who has granted medRxiv a license to display the preprint in perpetuity.

All rights reserved. No reuse allowed without permission.

\title{
WHO: World Health Organization
}

\section{WHOQOL-BREF: World Health Organization Quality of Life Questionnaire}

\author{
WP: Western Pacific
}

\section{References}

1. United Nations International Strategy for Disaster Reduction Secretariat. Global assessment report on disaster risk reduction (2009) [Internet]. Geneva (Switzerland): United Nations International Strategy for Disaster Reduction Secretariat (UNISDR); 2009[cited 2020 Aug 15]. Report No.: 9789211320282. Available from: https://www.undrr.org/publication/global-assessment-report-disasterrisk-reduction-2009

2. World Health Organization. Tobacco Use is Falling, but not fast enough. Geneva (Switzerland): World Health Organization; 2018.

3. Kohrt BA, Mistry AS, Anand N, Beecroft B, Nuwayhid I. Health research in humanitarian crises: an urgent global imperative. BMJ Glob Health. 2019;4(6):e001870-e.

4. www.ifrc.org [Internet]. Geneva: International Federation of Red Cross and Red Crescent Societies. What is a Disaster [Internet]?; c2020 [cited 2020 Aug 1]. Available from: Available from: http://www.ifrc.org/en/what-we-do/disaster-management/about-disasters/what-is-a-disaster/

5. Desai B, Maskrey A, Peduzzi P, De Bono A, Herold C. Making Development Sustainable: The Future of Disaster Risk Management, Global Assessment Report on Disaster Risk Reduction [Internet]. Geneva (Switzerland): United Nations International Strategy for Disaster Reduction Secretariat (UNISDR); 2015 [cited 2020 Aug 15]. Available from: https://archive-ouverte.unige.ch/unige:78299 6. Doocy S, Dick A, Daniels A, Kirsch TD. The human impact of tropical cyclones: a historical review of events 1980-2009 and systematic literature review. PLoS Curr. 2013;5:ecurrents.dis.2664354a5571512063ed29d25ffbce74.

7. Federal Emergency Management Agency. Unit four: emergency management in the United States [Internet]. Washington(DC): Federal Emergency Management Agency; 2013[cited 2020 Aug 1].

Available from: https://training.fema.gov/emiweb/downloads/is111_unit\%204.pdf

8. International Committee of the Red Cross. Protracted conflict and humanitarian action: some recent ICRC experiences [Internet]. Geneva (Switzerland): International Committee of the Red Cross; 2016 [cited 2020 Aug 15]. Available from:

https://www.icrc.org/sites/default/files/document/file_list/protracted_conflict_and_humanitarian_action_i crc_report_lr_29.08.16.pdf

9. International Committee of the Red Cross. Non-international armed conflict [Internet]. Geneva (Switzerland): International Committee of the Red Cross; 2020 [cited 2020 Sept 2]. Available from: https://casebook.icrc.org/glossary/non-international-armed-conflict

10. International Committee of the Red Cross. International armed conflict [Internet]. Geneva (Switzerland): International Committee of the Red Cross; 2020 [cited 2020 Sept 2]. Available from: https://casebook.icrc.org/glossary/international-armed-conflict

11. Schipper L, Pelling M. Disaster risk, climate change and international development: scope for, and challenges to, integration. Disasters. 2006;30(1):19-38.

12. Jamison DT. Disease Control Priorities, 3rd edition: improving health and reducing poverty. Lancet. 2018;391(10125):e11-e4.

13. United Nations High Commissioner for Refugees. UNHCR global trends report: Forced Displacement in 2019[Internet]. Geneva (Switzerland): United Nations High Commissioner for Refugees; 2020[cited 2020 Sept 2]. Available from: https://www.unhcr.org/enus/statistics/unhcrstats/5ee200e37/unhcr-global-trends-2019.html 
medRxiv preprint doi: https://doi.org/10.1101/2020.10.15.20213025; this version posted October 20, 2020. The copyright holder for this preprint (which was not certified by peer review) is the author/funder, who has granted medRxiv a license to display the preprint in perpetuity. All rights reserved. No reuse allowed without permission.

14. Kenerson JG. Hypertension in Haiti: the challenge of best possible practice. J Clin Hypertens (Greenwich). 2014;16(2):107-14.

15. Chan EY, Gao Y, Griffiths SM. Literature review of health impact post-earthquakes in China 1906-2007. J Public Health (Oxf). 2010;32(1):52-61.

16. Amara AH, Aljunid SM. Noncommunicable diseases among urban refugees and asylum-seekers in developing countries: a neglected health care need. Global Health. 2014;10:24.

17. Pielke R. Disasters Cost More than Ever - But Not Because of Climate Change. FiveThirtyEight [Internet]. 2014 Mar 19 [cited 2020 Aug 20]. Available from: https://fivethirtyeight.com/features/disasters-cost-more-than-ever-but-not-because-of-climate-change/.

18. World Health Organization. WHO global action plan: for the prevention and control of noncommunicable diseases 2013-2020 [Internet]. Geneva (Switzerland): World Health Organization; 2015. Available from: http://apps.who.int/iris/bitstream/10665/94384/1/9789241506236_eng.pdf

19. Kallab MG. Management of hypertension and diabetes for the Syrian refugees and host community in selected health facilities in Lebanon. Field Exchange Emergency Nutrition Network ENN. 2015;50:68-72.

20. Sibai AM, Fletcher A, Hills M, Campbell O. Non-communicable disease mortality rates using the verbal autopsy in a cohort of middle aged and older populations in Beirut during wartime, 1983-93. J Epidemiol Community Health. 2001;55(4):271-76.

21. Strong J, Varady C, Chahda N, Doocy S, Burnham G. Health status and health needs of older refugees from Syria in Lebanon. Confl Health. 2015;9:12.

22. Yusef JI. Management of diabetes mellitus and hypertension at UNRWA primary health care facilities in Lebanon. Eastern Mediterranean Health Journal. 2000;6(2-3):378-90.

23. World Health Organization. Chapter One: Chronic diseases: causes and health impact[Internet]. Geneva (Switzerland): World Health Organization; 2020[cited 2020 Sept 2]. Available from:

https://www.who.int/chp/chronic_disease_report/part2_ch1/en/index12.html\#: :text=These \%20causes\%2 0are\%20expressed\%20through,\%E2\%89\%A530\%20kg\%2Fm2.

24. Marjanovic K, Soldo-Butkovic S, Kralj M, Soldo I, Marjanovic M, Hanzer N, et al. The incidence of stroke in Baranya County (East Croatia). Collegium Antropologicum. 2003;27(2):547-54.

25. Kadojic D, Demarin V, Kadojic M, Mihaljevic I, Barac B. Influence of prolonged stress on risk factors for cerebrovascular disease. Collegium Antropologicum. 1999;23(1):213-9.

26. Hung KK, Lam EC, Chan EY, Graham CA. Disease pattern and chronic illness in rural China: the Hong Kong Red Cross basic health clinic after 2008 Sichuan earthquake. Emergency Medicine Australasia. 2013;25(3):252-9.

27. Sun XC, Zhou XF, Chen S, Liu YX, Wang YJ, Zhang W, et al. Clinical characteristics of hypertension among victims in temporary shield district after Wenchuan earthquake in China. Eur Rev Med Pharmacol Sci. 2013;17(7):912-6.

28. Markoglou NCh, Hatzitolios AI, Savopoulos ChG, Ziakas AG, Koutsopoulos D, Metallidis S. Epidemiologic characteristics of hypertension in the civilians of Kosovo after the war. Cent Eur J Public Health. 2005; 13(2):61-5.

29. Mousa HS, Yousef S, Riccardo F, Zeidan W, Sabatinelli G. Hyperglycaemia, hypertension and their risk factors among Palestine refugees served by UNRWA. Eastern Mediterranean Health Journal. 2010;16(6):609-14.

30. Mateen FJ, Carone M, Al-Saedy H, Nyce S, Ghosn J, Mutuerandu T, et al. Medical conditions among Iraqi refugees in Jordan: data from the United Nations Refugee Assistance Information System. Bull World Health Organ. 2012;90(6):444-51.

31. Vasilj I, Bergovec M, Kvesic A, Strnad M, Ostojic L, Ostojic Z, et al. Acute coronary syndrome frequency in western Herzegovina over the fifteen year period (1987-2001). Collegium Antropologicum. 2006;30(4):915-9.

32. Abukhdeir HF, Caplan LS, Reese L, Alema-Mensah E. Factors affecting the prevalence of chronic diseases in Palestinian people: an analysis of data from the Palestinian Central Bureau of Statistics. Eastern Mediterranean Health Journal. 2013;19(4):307-13. 
medRxiv preprint doi: https://doi.org/10.1101/2020.10.15.20213025; this version posted October 20, 2020. The copyright holder for this preprint (which was not certified by peer review) is the author/funder, who has granted medRxiv a license to display the preprint in perpetuity.

All rights reserved. No reuse allowed without permission.

33. Miric D, Giunio L, Bozic I, Fabijanic D, Martinovic D, Culic V. Trends in myocardial infarction in Middle Dalmatia during the war in Croatia. Military Medicine. 2001;166(5):419-21.

34. Armenian HK, Melkonian AK, Hovanesian AP. Long term mortality and morbidity related to degree of damage following the 1988 earthquake in Armenia. American Journal of Epidemiology. 1998;148(11):1077-84.

35. Chen Y, Li J, Xian H, Li J, Liu S, Liu G, et al. Acute cardiovascular effects of the Wenchuan earthquake: ambulatory blood pressure monitoring of hypertensive patients. Hypertens Res. 2009;32(9):797-800.

36. Vukovic DS, Krotin ME, Babic MM, Zivanovic BM. Anxiety level and responses to stress caused by air raids among patients with ischemic heart disease. Prehospital Disaster Med. 2005;20(4):249-52.

37. Ebrahimi SJ, Ebrahimzadeh L, Eslami A, Bidarpoor F. Effects of dust storm events on emergency admissions for cardiovascular and respiratory diseases in Sanandaj, Iran. J Environ Health Sci Eng. 2014;12:110.

38. Bergovec M, Heim I, Vasilj I, Jembrek-Gostovic M, Bergovec M, Strnad M. Acute coronary syndrome and the 1992-1995 war in Bosnia and Herzegovina: a 10-year retrospective study. Military Medicine. 2005;170(5):431-4.

39. Zubaid M, Suresh CG, Thalib L, Rashed W. Could missile attacks trigger acute myocardial infarction? Acta Cardiol. 2006;61(4):427-31.

40. Hult M, Tornhammar P, Ueda P, Chima C, Bonamy AK, Ozumba B, et al. Hypertension, diabetes and overweight: looming legacies of the Biafran famine. PLoS ONE. 2010;5(10):e13582.

41. Khader A, Farajallah L, Shahin Y, Hababeh M, Abu-Zayed I, Zachariah R, et al. Hypertension and treatment outcomes in Palestine refugees in United Nations Relief and Works Agency primary health care clinics in Jordan. Tropical Medicine and International Health. 2014;19(10):1276-83.

42. Otoukesh S, Mojtahedzadeh M, Sherzai D, Behazin A, Bazargan-Hejazi S, Bazargan M. A retrospective study of demographic parameters and major health referrals among Afghan refugees in Iran. Int J Equity Health. 2012;11:82.

43. Tomic V, Petrovic O, Petrov B, Bjelanovic V, Naletilic M. Hypertensive Disorders in Pregnancy: A 5-year Analysis of the Wartime and Postwar Period in South-Western Region of Bosnia and Herzegovina. Collegium Antropologicum. 2009;33:115-9.

44. Besancon S, Fall IS, Dore M, Sidibe A, Hagon O, Chappuis F, et al. Diabetes in an emergency context: the Malian case study. Confl Health. 2015;9:15.

45. Marom T, Segal D, Erlich T, Tsumi E, Merin O, Lin G. Ethical and clinical dilemmas in patients with head and neck tumors visiting a field hospital in the Philippines. Am J Disaster Med. 2014;9(3):2119.

46. Read DJ, Holian A, Moller CC, Poutawera V. Surgical workload of a foreign medical team after Typhoon Haiyan. ANZ J Surg. 2016;86(5):361-5.

47. Ebling B, Majnaric-Trtica L, Gmajnic R, Ebling Z, Vranjes Z. Psycho-social aspects of measures aimed at decreasing prevalence of chronic diseases in the population of returnees in the Osijek Region, Croatia. Collegium Antropologicum. 2007;31(2):441-50.

48. McKenzie ED, Spiegel P, Khalifa A, Mateen FJ. Neuropsychiatric disorders among Syrian and Iraqi refugees in Jordan: a retrospective cohort study 2012-2013. Confl Health. 2015;9:10.

49. Shamseddine A, Sibai AM, Gehchan N, Rahal B, El-Saghir N, Ghosn M, et al. Cancer incidence in postwar Lebanon: findings from the first national population-based registry, 1998. Annals of Epidemiology. 2004;14(9):663-8.

50. Li QD, Li H, Li FJ, Wang MS, Li ZJ, Han J, et al. Nutrition deficiency increases the risk of stomach cancer mortality. BMC Cancer. 2012;12:315.

51. Milojkovic M, Pajtler M, Rubin M. Influence of the war in Croatia on the frequency of gynecological cancer in the University Hospital Osijek in the period from 1985 to 2002. Collegium Antropologicum. 2005;29(2):573-8. 
medRxiv preprint doi: https://doi.org/10.1101/2020.10.15.20213025; this version posted October 20, 2020. The copyright holder for this preprint (which was not certified by peer review) is the author/funder, who has granted medRxiv a license to display the preprint in perpetuity.

All rights reserved. No reuse allowed without permission.

52. Telarović S, Telarović S, Relja M, Franinović-Marković J. Impact of war on central nervous system tumors incidence--a 15-year retrospective study in Istria County, Croatia. Coll Antropol. 2006;30(1):149-55.

53. Huynh ML, Raab SS, Suba EJ. Association between war and cervical cancer among Vietnamese women. International Journal of Cancer. 2004;110(5):775-7.

54. Crosbie EJ, Einstein MH, Franceschi S, Kitchener HC. Human papillomavirus and cervical cancer. the Lancet. 2013;382(9895):889-99.

55. Khan SM, Jawad G, Shagufta N, Salar Z. Cancer in north west Pakistan and Afghan refugees. Journal of the Pakistan Medical Association. 1997;47(4):122-4.

56. Wright RJ, Fay ME, Suglia SF, Clark CJ, Evans JS, Dockery DW, Behbehani J. War-related stressors are associated with asthma risk among older Kuwaitis following the 1990 Iraqi invasion and occupation. J Epidemiol Community Health. 2010;64(7):630-5.

57. Abul AT, Nair PC, Behbehanei NA, Sharma PN. Hospital admissions and death rates from asthma in Kuwait during pre- and post-Gulf War periods. Ann Allergy Asthma Immunol. 2001;86(4):465-8.

58. Bijani Kh, Moghadamnia AA. Long-term effects of chemical weapons on respiratory tract in Iraq-Iran war victims living in Babol (North of Iran). Ecotoxicol Environ Saf. 2002 Nov;53(3):422-4. 59. Mirsadraee M, Mozaffari A, Attaran D. Prevalence of asthma in children of chemical warfare victims. Iranian Journal of Pediatrics. 2011;21(3):294-300.

60. Lari SM, Ghobadi H, Attaran D, Mahmoodpour A, Shadkam O, Rostami M. COPD assessment test (CAT): simple tool for evaluating quality of life of chemical warfare patients with chronic obstructive pulmonary disease. Clin Respir J. 2014;8(1):116-23.

61. Forouzan A, Masoumi K, Haddadzadeh Shoushtari M, Idani E, Tirandaz F, Feli M, et al. An overview of thunderstorm-associated asthma outbreak in southwest of Iran. J Environ Public Health. 2014;2014:504017.

62. Kunii O, Kanagawa S, Yajima I, Hisamatsu Y, Yamamura S, Amagai T, et al. The 1997 haze disaster in Indonesia: its air quality and health effects. Archives of Environmental Health. 2002;57(1):1622.

63. Naumova EN, Yepes H, Griffiths JK, Sempertegui F, Khurana G, Jagai JS, et al. Emergency room visits for respiratory conditions in children increased after Guagua Pichincha volcanic eruptions in April 2000 in Quito, Ecuador observational study: time series analysis. Environmental Health. 2007;6(21).

64. Guha-Sapir D, van Panhuis WG, Lagoutte J. Short communication: patterns of chronic and acute diseases after natural disasters - a study from the International Committee of the Red Cross field hospital in Banda Aceh after the 2004 Indian Ocean tsunami. Trop Med Int Health. 2007;12(11):1338-41.

65. Redwood-Campbell LJ, Riddez L. Post-Tsunami medical care: health problems encountered in the International Committee of the Red Cross hospital in Banda Aceh, Indonesia. Prehospital and Disaster Medicine. 2006;21(1):s1-s7.

66. El-Sharif N, Abdeen Z, Qasrawi R, Moens G, Nemery B. Asthma prevalence in children living in villages, cities and refugee camps in Palestine. Eur Respir J. 2002;19(6):1026-34.

67. Molla NA, Mollah KA, Fungladda W, Ramasoota P. Multidisciplinary household environmental factors: influence on DALYs lost in climate refugees community. Environmental Development. 2014;9:111.

68. An C, Zhang Y, Yu L, Li N, Song M, Wang L, et al. Long-term impact of earthquake stress on fasting glucose control and diabetes prevalence among Chinese adults of Tangshan. Int J Clin Exp Med. 2014;7(11):4441-7.

69. Karrouri R. Post traumatic type 1 diabetes mellitus (insulin-dependent): a case report. Pan African Medical Journal. 2014;19(328).

70. Ramachandran A, Snehalatha C, Yamuna A, Bhaskar AD, Simon M, Vijay V, et al. Stress and undetected hyperglycemia in southern Indian coastal population affected by tsunami. J Assoc Physicians India. 2006;54:109-12. 
medRxiv preprint doi: https://doi.org/10.1101/2020.10.15.20213025; this version posted October 20, 2020. The copyright holder for this preprint (which was not certified by peer review) is the author/funder, who has granted medRxiv a license to display the preprint in perpetuity.

All rights reserved. No reuse allowed without permission.

71. Eljedi A, Mikolajczyk RT, Kraemer A, Laaser U. Health-related quality of life in diabetic patients and controls without diabetes in refugee camps in the Gaza strip: a cross-sectional study. BMC Public Health. 2006;6(268).

72. Sengul A, Ozer E, Salman S, Salman F, Saglam Z, Sargin M, et al. Lessons learnt from influences of the Marmara earthquake on glycemic control and quality of life in people with type 1 diabetes. Endocr J. 2004;51(4):407-14.

73. Li Y, He Y, Qi L, Jaddoe VW, Feskens EJ, Yang X, et al. Exposure to the Chinese famine in early life and the risk of hyperglycemia and type 2 diabetes in adulthood. Diabetes. 2010;59(10):2400-6.

74. Lumey LH, Khalangot MD, Vaiserman AM. Association between type 2 diabetes and prenatal exposure to the Ukraine famine of 1932-33: a retrospective cohort study. Lancet Diabetes Endocrinol. 2015;3(10):787-94.

75. Habtu E, Gill G, Tesfaye S. Characteristics of insulin requiring diabetes in rural Northern Ethiopia - a possible link with malnutrition? Ethiopian Medical Journal. 1999;37(4):263-7.

76. Mansour AA. Patients' opinion on the barriers to diabetes control in areas of conflicts: The Iraqi example. Confl Health. 2008;2:7.

77. Balabanova D, McKee M, Koroleva N, Chikovani I, Goguadze K, Kobaladze T, et al. Navigating the health system: diabetes care in Georgia. Health Policy Plan. 2009;24(1):46-54.

78. Khader A, Ballout G, Shahin Y, Hababeh M, Farajallah L, Zeidan W, et al. Diabetes mellitus and treatment outcomes in Palestine refugees in UNRWA primary health care clinics in Jordan. Public Health Action. 2013;3(4):259-64.

79. Khader A, Ballout G, Shahin Y, Hababeh M, Farajallah L, Zeidan W, et al. What happens to Palestine refugees with diabetes mellitus in a primary healthcare centre in Jordan who fail to attend a quarterly clinic appointment? Tropical Medicine and International Health. 2014;19(3):308-12.

80. Khader A, Ballout G, Shahin Y, Hababeh M, Farajallah L, Zeidan W, et al. Treatment outcomes in a cohort of Palestine refugees with diabetes mellitus followed through use of E-Health over 3 years in Jordan. Trop Med Int Health. 2014;19(2):219-23.

81. Khader A, Farajallah L, Shahin Y, Hababeh M, Abu-Zayed I, Kochi A, et al. Cohort monitoring of persons with diabetes mellitus in a primary healthcare clinic for Palestine refugees in Jordan. Trop Med Int Health. 2012;17(12):1569-76.

82. Ali-Shtayeh MS, Jamous RM, Jamous RM. Complementary and alternative medicine use amongst Palestinian diabetic patients. Complement Ther Clin Pract. 2012;18(1):16-21.

83. Sofeh ASA, Khan AS, Khan MA. Diabetes mellitus and its concomitant disorders in Afghan Refugees residing in Peshawar, Pakistan. Journal of Postgraduate Medical Institute. 2004;18(3):359-67. 84. AlKasseh AS, Zaki NM, Aljeesh YI, Soon LK. Risk factors of gestational diabetes mellitus in the refugee population in Gaza Strip: a case-control study. East Mediterr Health J. 2014;19(Suppl 3):S12-8. 85. Ahmad B, Fouad FM, Elias M, Zaman S, Phillimore P, Maziak W. Health system challenges for the management of cardiovascular disease and diabetes: an empirical qualitative study from Syria. Int J Public Health. 2015;60(Suppl 1):S55-62.

86. Ben Romdhane H, Tlili F, Skhiri A, Zaman S, Phillimore P. Health system challenges of NCDs in Tunisia. Int J Public Health. 2015;60:S39-S46.

87. Mateen FJ, Carone M, Haskew C, Spiegel P. Reportable neurologic diseases in refugee camps in 19 countries. Neurology. 2012;79(9):937-40.

88. Khateri S, Ghanei M, Keshavarz S, Soroush M, Haines D. Incidence of lung, eye, and skin lesions as late complications in 34,000 Iranians with wartime exposure to mustard agent. J Occup Environ Med. 2003;45(11):1136-43.

89. Amini R, Haghani H, Masoumi M. Quality of life in the Iranian Blind War Survivors in 2007: a cross-sectional study. BMC Int Health Hum Rights. 2010;10:21.

90. Leeuw L. The situation of older refugees and refugees with disabilities, injuries, and chronic diseases in the Syria crisis. Field Exchange Emergency Nutrition Network ENN. 2014;48:90-2. 
medRxiv preprint doi: https://doi.org/10.1101/2020.10.15.20213025; this version posted October 20, 2020. The copyright holder for this preprint (which was not certified by peer review) is the author/funder, who has granted medRxiv a license to display the preprint in perpetuity.

All rights reserved. No reuse allowed without permission.

91. Chan EY, Kim JJ. Characteristics and health outcomes of internally displaced population in unofficial rural self-settled camps after the 2005 Kashmir, Pakistan earthquake. Eur J Emerg Med. 2010;17(3):136-41.

92. Daniels A, Chapin E, Aspilcueta D, Doocy S. Access to health services and care-seeking behaviors after the 2007 ica earthquake in Peru. Disaster Medicine and Public Health Preparedness. 2009;3(2):97-103.

93. Gilder ME, Zin TW, Wai NS, Ner M, Say PS, Htoo M, et al. Gestational diabetes mellitus prevalence in Maela refugee camp on the Thai-Myanmar border: a clinical report. Global Health Action. 2014;7(23887).

94. Yaghi K, Yaghi Y, McDonald AA, Yadegarfar G, Cecil E, Seidl J, et al. Diabetes or war? Incidence of and indications for limb amputation in Lebanon, 2007. East Mediterr Health J. 2012;18(12):1178-86.

95. Huerga H, Vasset B, Prados E. Adult and paediatric mortality patterns in a referral hospital in Liberia 1 year after the end of the war. Trans R Soc Trop Med Hyg. 2009;103(5):476-84.

96. Wu J, Xiao J, Li T, Li X, Sun H, Chow EP, et al. A cross-sectional survey on the health status and the health-related quality of life of the elderly after flood disaster in Bazhong city, Sichuan, China. BMC Public Health. 2015;15:163.

97. Proimos J, Klein JD. Noncommunicable Diseases in Children and Adolescents. Pediatrics. 2012;130(3):379.

98. Catalano RF, Fagan AA, Gavin LE, Greenberg MT, Irwin CE Jr, Ross DA, et al. Worldwide application of prevention science in adolescent health. Lancet. 2012;379(9826):1653-64.

99. United Nations Office for the Coordination of Humanitarian Affairs. Greater horn of Africa region: humanitarian snapshot[Internet]. Geneva (Switzerland): United Nations Office for the Coordination of Humanitarian Affairs; 2015[cited 2020 Sept 2]. Available from:

https://reliefweb.int/report/ethiopia/greater-horn-africa-region-humanitarian-snapshot-april-2020

100. Cue W, Núñez-Flores VR. According to need? Humanitarian responses to violence in Central America [Internet]. Geneva (Switzerland): United Nations Office for the Coordination of Humanitarian Affairs; 2017[cited 2020 Sept 2]. Available from: https://www.unocha.org/fr/story/according-needhumanitarian-responses-violence-central-america

101. United Nations Office for the Coordination of Humanitarian Affairs. East Africa locust infestation 2020 [Internet]. Geneva (Switzerland): United Nations Office for the Coordination of Humanitarian Affairs; 2017[cited 2020 Sept 2]. Available from: https://www.unocha.org/east-africalocust-infestation

102. United Nations Office for the Coordination of Humanitarian Affairs. Natural disasters in Latin America and the Caribeean 2000-2019 [Internet]. Geneva (Switzerland): United Nations Office for the Coordination of Humanitarian Affairs; 2020[cited 2020 Sept 2]. Available from:

https://reliefweb.int/report/world/natural-disasters-latin-america-and-caribbean-2000-2019

103. Anauati MV, Galiani S, Weinschelbaum F. The rise of noncommunicable diseases in Latin America and the Caribbean: challenges for public health policies. Latin American Economic Review. 2015;24(1):11.

104. World Health Organization. Noncommunicable Diseases WHO Africa. Geneva (Switzerland): World Health Organization; 2020[cited 2020 Sept 2]. Available from: https://www.afro.who.int/healthtopics/noncommunicable-diseases

105. Alabed S, Guul A, Crighton C, Alahdab F, Fares M, Morad M, et al. An assessment of diabetes care in Palestinian refugee camps in Syria. Avicenna J Med. 2014;4(3):66-70.

106. International Diabetes Federation. IDF Diabetes Atlas 9th Edition [Internet]. Brussels (Belgium): International Diabetes Federation; 2019 [cited 2020 Sept 2]. Available from:

https://www.diabetesatlas.org/en/

107. Dangou J-M. The prevalence of diabetes in the African region. Open Access Government [Internet]. 2019 Sept 11 [cited 2020 Sept 20]. Available from:

https://www.openaccessgovernment.org/diabetes-african-region/73153/ 
medRxiv preprint doi: https://doi.org/10.1101/2020.10.15.20213025; this version posted October 20, 2020. The copyright holder for this preprint (which was not certified by peer review) is the author/funder, who has granted medRxiv a license to display the preprint in perpetuity.

All rights reserved. No reuse allowed without permission.

108. Vasilj I, Pilav A, Maslov B, Polasek O. Cardiovascular Risk Factors Research in Bosnia and Herzegovina. Collegium Antropologicum. 2009;33:185-8.

109. Li Y, Jaddoe VW, Qi L, He Y, Wang D, Lai J, et al. Exposure to the Chinese famine in early life and the risk of metabolic syndrome in adulthood. Diabetes Care. 2011;34(4):1014-8.

110. Khan MMH, Gruebner O, Kramer A. Is area affected by flood or stagnant water independently associated with poorer health outcomes in urban slums of Dhaka and adjacent rural areas? Natural Hazards. 2014;70(1):549-65.

111. Sphere Association. The Sphere Handbook: Humanitarian Charter and Minimum Standards in Humanitarian Response [Internet]. Geneva (Switzerland): Sphere Association; 2018[cited 2020 Sept 23]. Available from: https://spherestandards.org/wp-content/uploads/Sphere-Handbook-2018-EN.pdf 112. World Health Organization. Noncommunicable Diseases in Emergencies [Internet]. Geneva (Switzerland): World Health Organization; 2016[cited 2020 Sept 23]. Available from: https://www.who.int/ncds/publications/ncds-in-emergencies/en/

113. World Health Organization. Package of Essential Noncommunicable (PEN) disease interventions for primary health care in low-resource settings [Internet]. Geneva (Switzerland): World Health Organization; 2013 [cited 2015 Sept 23]. Available from:

http://www.who.int/cardiovascular_diseases/publications/implementation_tools_WHO_PEN/en/

114. Doocy S, Lyles E, Roberton T, Akhu-Zaheya L, Oweis A, Burnham G. Prevalence and careseeking for chronic diseases among Syrian refugees in Jordan. BMC Public Health. 2015;15(1):1097.

115. Doocy S, Sirois A, Tileva M, Storey JD, Burnham G. Chronic disease and disability among Iraqi populations displaced in Jordan and Syria. Int J Health Plann Manage. 2013;28(1):e1-e12.

116. Anderson RE, Grant L. What is the value of palliative care provision in low-resource settings? BMJ Glob Health. 2017;2(1):e000139.

117. Li QD, Li H, Li FJ, Wang MS, Li ZJ, Han J, et al. Nutrition deficiency increases the risk of stomach cancer mortality. BMC Cancer. 2012;12:315.

118. Li Y, He Y, Qi L, Jaddoe VW, Feskens EJ, Yang X, et al. Exposure to the Chinese famine in early life and the risk of hyperglycemia and type 2 diabetes in adulthood. Diabetes. 2010;59(10):2400-6. 119. Laaser U, Beluli F. Special Volume 2016, A Global Public Health Curriculum (2nd Edition). South Eastern European Journal of Public Health. 2016. doi: 10.4119/seejph-1828.

120. World Health Organization. The WHO STEPwise approach to noncommunicable disease risk factor surveillance (STEPS) [Internet]. Geneva (Switzerland): World Health Organization; 2016[cited 2015 Sept 23]. Available from: www.who.int/ncds/steps

121. USAID. Demographic and Health Surveys [Internet]. Washington (DC): USAID; 2020 [cited 2020 Sept 30]. Available from: https://dhsprogram.com/

122. Sibai AM, Yount KM, Fletcher A. Marital status, intergenerational co-residence and cardiovascular and all-cause mortality among middle-aged and older men and women during wartime in Beirut: gains and liabilities. Soc Sci Med. 2007;64(1):64-76. doi: 10.1016/j.socscimed.2006.08.006. 123. Wagner J, Keuky L, Fraser-King L, Kuoch T, Scully M. Training Cambodian Village Health Support Guides in Diabetes Prevention: Effects on Guides' Knowledge and Teaching Activities Over 6 Months. Int J Behav Med. 2016;23(2):162-7.

124. Chan EY, Griffiths S. Comparision of health needs of older people between affected rural and urban areas after the 2005 Kashmir, Pakistan earthquake. Prehospital Disaster Med. 2009;24(5):365-71. 125. Chan EY, Kim J. Chronic health needs immediately after natural disasters in middle-income countries: the case of the 2008 Sichuan, China earthquake. European Journal of Emergency Medicine. 2011;18(2):111-4. 


\section{Tables}

Table 1: Characteristics of included publications by disease type: Cardiovascular Disease

\begin{tabular}{|c|c|c|c|c|c|c|c|}
\hline & $\begin{array}{c}\text { Country/ } \\
\text { Territory of } \\
\text { Interest }\end{array}$ & $\begin{array}{l}\text { WHO } \\
\text { region }\end{array}$ & Type of study & Target Population & $\begin{array}{c}\text { Years of } \\
\text { observation }\end{array}$ & $\begin{array}{c}\text { Number of } \\
\text { study } \\
\text { participants }\end{array}$ & Major findings \\
\hline $\begin{array}{l}\text { Abukhdeir } \\
(2013)(32)\end{array}$ & $\begin{array}{c}\text { Palestinian } \\
\text { Territories: } \\
\text { West } \\
\text { Bank/Gaza }\end{array}$ & EMRO & Cross sectional & $\begin{array}{c}\text { Palestinian households } \\
\text { in the West Bank and } \\
\text { Gaza Strip }\end{array}$ & $\begin{array}{l}\text { May } 2004 \text { - } \\
\text { July } 2004\end{array}$ & $\begin{array}{c}4,456 \\
\text { households } \\
\text { in the West } \\
\text { Bank and } \\
2118 \text { in the } \\
\text { Gaza Strip }\end{array}$ & $\begin{array}{c}\text { Being a refugee was a } \\
\text { significant risk factor } \\
\text { for CVD while being } \\
\text { married/engaged or } \\
\text { divorced/separated/ } \\
\text { widowed was a risk } \\
\text { factor for } \\
\text { hypertension. Non- } \\
\text { refugees were } 46 \% \\
\text { less likely to have } \\
\text { CVD than refugees. } \\
\text { Gender was a risk } \\
\text { factor for hypertension } \\
\text { with females being } \\
60 \% \text { more likely to } \\
\text { have hypertension } \\
\text { than males. Age was a } \\
\text { significant risk factor } \\
\text { for hypertension and } \\
\text { CVD(p }<0.0001) \text {. }\end{array}$ \\
\hline $\begin{array}{c}\text { Ahmad } \\
(2015)(85)\end{array}$ & Syria & EMRO & $\begin{array}{l}\text { Situational } \\
\text { analysis using } \\
\text { document } \\
\text { analysis, key } \\
\text { informant } \\
\text { interviews, and } \\
\text { direct clinic } \\
\text { observation }\end{array}$ & $\begin{array}{c}\text { Syrian national health } \\
\text { system }\end{array}$ & $\begin{array}{c}\text { October } \\
2009- \\
\text { August } 2010\end{array}$ & $\begin{array}{l}53 \text { semi- } \\
\text { structured } \\
\text { interviews }\end{array}$ & $\begin{array}{l}\text { The rebuilding of a } \\
\text { post-conflict heath } \\
\text { care system in Syria } \\
\text { may benefit from } \\
\text { insights into the } \\
\text { structural problems of } \\
\text { the pre-crisis system. } \\
\text { Weaknesses that } \\
\text { existed before the } \\
\text { crisis are compounded } \\
\text { by the current conflict. }\end{array}$ \\
\hline $\begin{array}{l}\text { Armenian } \\
(1998)(34)\end{array}$ & Armenia & Europe & $\begin{array}{l}\text { Retrospective } \\
\text { cohort }\end{array}$ & $\begin{array}{l}\text { Employees of the } \\
\text { Armenian Ministry of } \\
\text { Health and their } \\
\text { immediate families who } \\
\text { survived the } 1988 \\
\text { Earthquake in Armenia }\end{array}$ & 1990-1992 & $\begin{array}{c}35,043 \\
\text { persons } \\
(7,721 \\
\text { employees } \\
\text { who had } \\
\text { survived the } \\
\text { disaster and } \\
\text { their family } \\
\text { members) }\end{array}$ & $\begin{array}{l}\text { The nested case- } \\
\text { control analysis of } 483 \\
\text { cases of newly } \\
\text { reported heart disease } \\
\text { and } 482 \text { matched non- } \\
\text { heart-disease controls } \\
\text { revealed that people } \\
\text { with increasing levels } \\
\text { of loss of material } \\
\text { possessions and } \\
\text { family members had } \\
\text { significant increases in } \\
\text { heart disease risk (OR } \\
\text { for "loss scores" of } 1 \text {, } \\
2 \text {, and } 3 \text { were } 1.3,1.8, \\
\text { and } 2.6, \text { respectively). }\end{array}$ \\
\hline $\begin{array}{l}\text { Ben } \\
\text { Romdhane } \\
(2015)(86)\end{array}$ & Tunisia & EMRO & $\begin{array}{l}\text { Situational } \\
\text { analysis }\end{array}$ & $\begin{array}{c}\text { Tunisian national health } \\
\text { system }\end{array}$ & 2010 & $\begin{array}{c}12 \text { key } \\
\text { informants } \\
\text { were } \\
\text { interviewed } \\
\text { and eight } \\
\text { documents } \\
\text { were } \\
\text { reviewed }\end{array}$ & $\begin{array}{l}\text { Weaknesses that } \\
\text { existed before the } \\
2011 \text { Revolution } \\
\text { (Arab Spring) were } \\
\text { compounded during } \\
\text { the revolution. This } \\
\text { study was conducted } \\
\text { prior to political } \\
\text { conflict but written } \\
\text { post-conflict. Growth } \\
\text { of the private sector } \\
\text { fostered unequal } \\
\text { access by } \\
\text { socioeconomic status } \\
\text { and reduced }\end{array}$ \\
\hline
\end{tabular}


medRxiv preprint doi: https://doi.org/10.1101/2020.10.15.20213025; this version posted October 20, 2020. The copyright holder for this preprint

(which was not certified by peer review) is the author/funder, who has granted medRxiv a license to display the preprint in perpetuity.

All rights reserved. No reuse allowed without permission.

\begin{tabular}{|c|c|c|c|c|c|c|c|}
\hline & $\begin{array}{c}\text { Country/ } \\
\text { Territory of } \\
\text { Interest }\end{array}$ & $\begin{array}{c}\text { WHO } \\
\text { region }\end{array}$ & Type of study & Target Population & $\begin{array}{c}\text { Years of } \\
\text { observation }\end{array}$ & $\begin{array}{l}\text { Number of } \\
\text { study } \\
\text { participants }\end{array}$ & Major findings \\
\hline & & & & & & & $\begin{array}{l}\text { coordination and } \\
\text { preparedness of the } \\
\text { health system. }\end{array}$ \\
\hline $\begin{array}{l}\text { Bergovec } \\
(2005)(38)\end{array}$ & $\begin{array}{c}\text { Bosnia and } \\
\text { Herzegovina }\end{array}$ & Europe & $\begin{array}{l}\text { Retrospective } \\
\text { chart review }\end{array}$ & $\begin{array}{c}\text { The population that } \\
\text { lived in Mostar and the } \\
\text { nine neighboring } \\
\text { districts prior to the } \\
\text { Bosnian War(1992- } \\
\text { 1995) }\end{array}$ & $\begin{array}{c}\text { Five } \\
\text { consecutive } \\
\text { years (1987- } \\
\text { 1991) before } \\
\text { the war and } \\
5 \\
\text { consecutive } \\
\text { years (1992- } \\
\text { 1996) during } \\
\text { the war were } \\
\text { analyzed. }\end{array}$ & $\begin{array}{l}182,000 \\
\text { persons per } \\
\text { the } 1991 \\
\text { census }\end{array}$ & $\begin{array}{c}\text { There was a wartime } \\
\text { increase in acute } \\
\text { myocardial } \\
\text { infarctions(AMI) for } \\
\text { the total population } \\
\text { ( } \mathrm{p}=0.025 \text { ). There was } \\
\text { a statistically } \\
\text { significant increase } \\
\text { ( } \mathrm{p}=0.001 \text { ) in the total } \\
\text { number of unstable } \\
\text { angina pectoris(UA) } \\
\text { cases during the war } \\
\text { (185 cases, compared } \\
\text { with } 125 \text { prewar } \\
\text { cases). Females } \\
\text { experienced a } \\
\text { statistically significant } \\
\text { increase in UA and } \\
\text { AMI }(\mathrm{p}=0.001,0.007 \\
\text { respectively) whereas } \\
\text { the increase among } \\
\text { men was not } \\
\text { statistically significant } \\
\text { (p=0.072, } \mathrm{p}=0.354 \\
\text { respectively). }\end{array}$ \\
\hline $\begin{array}{c}\text { Chen } \\
(2009)(35)\end{array}$ & China & $\begin{array}{l}\text { Western } \\
\text { Pacific }\end{array}$ & Case series & $\begin{array}{l}\text { Adults who were in the } \\
\text { West China Hospital on } \\
\text { the day of the } 2008 \\
\text { Sichuan (Wenchuan) } \\
\text { earthquake }\end{array}$ & May 2008 & 11 patients & $\begin{array}{l}\text { Mean blood pressure } \\
\text { and heart rate } \\
\text { increased immediately } \\
\text { after the earthquake, } \\
\text { regardless of gender or } \\
\text { pre-existing } \\
\text { hypertension. BP } \\
\text { gradually declined } \\
\text { within } 6 \text { hours after } \\
\text { the earthquake and } \\
\text { increased again during } \\
\text { aftershocks. Circadian } \\
\text { variation was absent in } \\
\text { all cases. }\end{array}$ \\
\hline $\begin{array}{c}\text { Ebling } \\
(2007)(47)\end{array}$ & Croatia & Europe & $\begin{array}{c}\text { Multipart study } \\
\text { including both } \\
\text { a retrospective } \\
\text { cohort study } \\
\text { and an } \\
\text { uncontrolled } \\
\text { before-after } \\
\text { study }\end{array}$ & $\begin{array}{c}\text { Refugee-returnees of the } \\
\text { 1991-1992 war } \\
\text { operations in Eastern } \\
\text { Slavonia from Osjek- } \\
\text { Baranga County, } \\
\text { Croatia }\end{array}$ & 2003 & $\begin{array}{l}\text { retrospective } \\
\text { cohort } \\
\text { study: } 589 \\
\text { participants } \\
\\
\text { uncontrolled } \\
\text { before-after } \\
\text { study } 202 \\
\text { participants }\end{array}$ & $\begin{array}{c}\text { Single counseling } \\
\text { session aimed at } \\
\text { lifestyle changes can } \\
\text { be effective at } \\
\text { decreasing CVD risk } \\
\text { factors. The } \\
\text { participation of } \\
\text { subjects with high } \\
\text { blood pressure } \\
\text { in the population of } \\
\text { displaced returnees, } \\
\text { exceeded the } \\
\text { values for both } \\
\text { Slavonia and Croatia } \\
\text { census data. }\end{array}$ \\
\hline $\begin{array}{l}\text { Ebrahimi } \\
(2014)(37)\end{array}$ & Iran & EMRO & Cross sectional & $\begin{array}{c}\text { Patients with } \\
\text { cardiovascular and } \\
\text { respiratory diseases who } \\
\text { received medical } \\
\text { services from the Center } \\
\text { for Disaster and } \\
\text { Emergency Medicine in } \\
\text { Sanandaj, Iran during } \\
\text { dust event days }\end{array}$ & $\begin{array}{l}\text { March } 2009 \\
\text { - June } 2010\end{array}$ & -- & $\begin{array}{c}\text { A statistically } \\
\text { significant increase in } \\
\text { emergency admissions } \\
\text { for cardiovascular } \\
\text { diseases was } \\
\text { demonstrated during } \\
\text { dust storm episodes in } \\
\text { Sanandaj, } \\
\text { Iran }(\text { correlation } \\
\text { coefficient }(\mathrm{r})=0.48,\end{array}$ \\
\hline
\end{tabular}


medRxiv preprint doi: https://doi.org/10.1101/2020.10.15.20213025; this version posted October 20, 2020. The copyright holder for this preprint (which was not certified by peer review) is the author/funder, who has granted medRxiv a license to display the preprint in perpetuity. All rights reserved. No reuse allowed without permission.

\begin{tabular}{|c|c|c|c|c|c|c|c|}
\hline & $\begin{array}{l}\text { Country/ } \\
\text { Territory of } \\
\text { Interest }\end{array}$ & $\begin{array}{c}\text { WHO } \\
\text { region }\end{array}$ & Type of study & Target Population & $\begin{array}{c}\begin{array}{c}\text { Years of } \\
\text { observation }\end{array} \\
\end{array}$ & $\begin{array}{l}\text { Number of } \\
\text { study } \\
\text { participants }\end{array}$ & Major findings \\
\hline & & & & & & & $\mathrm{p}<0.05)$ \\
\hline $\begin{array}{c}\text { Huerga } \\
(2009)(95)\end{array}$ & Liberia & Africa & $\begin{array}{l}\text { Retrospective } \\
\text { chart review }\end{array}$ & $\begin{array}{l}\text { Patients of the medical } \\
\text { and pediatric wards of } \\
\text { Mamba Point Hospital, } \\
\text { Monrovia, Liberia, one } \\
\text { year after the end of the } \\
\text { Liberian civil } \\
\text { war }\end{array}$ & $\begin{array}{c}\text { January } \\
2005 \text { - July } \\
2005\end{array}$ & $\begin{array}{c}1,034 \text { adult } \\
\text { patients } \\
1,509 \\
\text { children }\end{array}$ & $\begin{array}{c}\text { Non- infectious } \\
\text { diseases accounted for } \\
56 \% \text { of the adult } \\
\text { deaths. The main } \\
\text { causes of death were } \\
\text { meningitis ( } 16 \%), \\
\text { stroke (14\%) and heart } \\
\text { failure } \\
(10 \%) \text {. Cardiovascular } \\
\text { diseases caused half of } \\
\text { deaths due to non- } \\
\text { infectious diseases: } \\
25 \% \text { stroke, } 18 \% \text { heart } \\
\text { failure, and } 10 \% \\
\text { severe hypertension. } \\
\text { No cases of ischemic } \\
\text { heart disease were } \\
\text { identified. }\end{array}$ \\
\hline $\begin{array}{c}\text { Hult } \\
(2010)(40)\end{array}$ & Nigeria & Africa & $\begin{array}{l}\text { Retrospective } \\
\text { cohort }\end{array}$ & $\begin{array}{l}40 \text { year old Nigerians } \\
\text { with fetal exposure to } \\
\text { famine in Biafra, } \\
\text { Nigeria during the } \\
\text { Nigerian civil war } \\
\quad(1967-1970)\end{array}$ & $\begin{array}{c}\text { June } 2009- \\
\text { July } 2009\end{array}$ & $\begin{array}{l}1,339 \text { study } \\
\text { participants }\end{array}$ & $\begin{array}{c}\text { Fetal-infant exposure } \\
\text { to famine was } \\
\text { associated with } \\
\text { elevated systolic ( }+7 \\
\text { mmHg; } \mathrm{p}<0.001) \text { and } \\
\text { diastolic }(+5 \mathrm{mmHg} \\
\mathrm{p}<0.001) \text { blood } \\
\text { pressure, waist } \\
\text { circumference }(+3 \mathrm{~cm} \text {, } \\
\text { p }<0.001) \text {, increased } \\
\text { risk of systolic } \\
\text { hypertension (adjusted } \\
\text { OR } 2.87 ; 95 \% \mathrm{CI} \\
1.90-4.34), \text { and } \\
\text { overweight status (OR } \\
1.41 ; 95 \% \mathrm{CI} 1.03- \\
1.93 \text { ) as compared to } \\
\text { people born after the } \\
\text { famine. }\end{array}$ \\
\hline $\begin{array}{c}\text { Hung } \\
\text { (2013) (26) }\end{array}$ & China & $\begin{array}{l}\text { Western } \\
\text { Pacific }\end{array}$ & $\begin{array}{l}\text { Retrospective } \\
\text { chart review }\end{array}$ & $\begin{array}{l}\text { Patients treated by Hong } \\
\text { Kong Red Cross three } \\
\text { weeks after the } 2008 \\
\text { Sichuan earthquake }\end{array}$ & June 2008 & $\begin{array}{l}\text { 2,034 patient } \\
\text { encounters }\end{array}$ & $\begin{array}{l}\text { There was a high } \\
\text { prevalence of chronic } \\
\text { disease after the } \\
\text { earthquake, especially } \\
\text { hypertension. } 43.4 \% \\
\text { of the } 762 \text { patients } \\
\text { with blood pressure } \\
\text { measurements were } \\
\text { above the recognized } \\
\text { criteria for } \\
\text { hypertension. }\end{array}$ \\
\hline $\begin{array}{c}\text { Kadojic } \\
(1999)(25)\end{array}$ & Croatia & Europe & Cohort study & $\begin{array}{l}\text { Displaced persons aged } \\
\text { 20-60y with signs of } \\
\text { PTSD and a history of } \\
\text { traumatic war } \\
\text { experience living in a } \\
\text { displaced persons camp } \\
\text { since } 1991\end{array}$ & -- & $\begin{array}{c}120 \\
\text { displaced } \\
\text { persons }\end{array}$ & $\begin{array}{l}\text { Displaced persons in } \\
\text { Croatia residing in } \\
\text { camps had a } \\
\text { significantly higher } \\
\text { prevalence }(\mathrm{p}<0.05) \\
\text { of hypertension, } \\
\text { hyperlipidemia, and } \\
\text { obesity when } \\
\text { compared to age- } \\
\text { matched controls in } \\
\text { settlements adjacent to } \\
\text { the study population } \\
\text { not impacted by the } \\
\text { war. Total risk for } \\
\text { stroke was higher in } \\
\text { the exposed group }(\mathrm{p}< \\
0.05 \text {. }\end{array}$ \\
\hline Kallab & Country of & EMRO & Program & Syrian refugees and & November & & Of the 1,825 patients \\
\hline
\end{tabular}


medRxiv preprint doi: https://doi.org/10.1101/2020.10.15.20213025; this version posted October 20, 2020. The copyright holder for this preprint

(which was not certified by peer review) is the author/funder, who has granted medRxiv a license to display the preprint in perpetuity.

All rights reserved. No reuse allowed without permission.

\begin{tabular}{|c|c|c|c|c|c|c|c|}
\hline & $\begin{array}{c}\text { Country/ } \\
\text { Territory of } \\
\text { Interest } \\
\end{array}$ & $\begin{array}{l}\text { WHO } \\
\text { region }\end{array}$ & Type of study & Target Population & $\begin{array}{c}\text { Years of } \\
\text { observation }\end{array}$ & $\begin{array}{c}\text { Number of } \\
\text { study } \\
\text { participants }\end{array}$ & Major findings \\
\hline (2015)(19) & $\begin{array}{l}\text { Asylum: } \\
\text { Lebanon } \\
\text { Country of } \\
\text { Origin: } \\
\text { Syria }\end{array}$ & & $\begin{array}{l}\text { implementation } \\
\text { reflection }\end{array}$ & $\begin{array}{c}\text { vulnerable Lebanese } \\
\text { being treated in } 8 \text { health } \\
\text { facilities run by Amel } \\
\text { Association } \\
\text { International }\end{array}$ & $\begin{array}{l}\text { 2014- May } \\
2015\end{array}$ & $\begin{array}{c}1,825 \\
\text { patients }\end{array}$ & $\begin{array}{c}\text { enrolled in the } \\
\text { program hypertension } \\
\text { and diabetes } \\
\text { accounted for } 46 \% \\
\text { and } 27 \% \text { of cases } \\
\text { respectively, with the } \\
\text { remaining } 27 \% \text { of } \\
\text { patients presenting } \\
\text { with both diseases. } \\
\text { Major challenges } \\
\text { included medications } \\
\text { shortages and cost, } \\
\text { insecurity, patient } \\
\text { transportation cost, } \\
\text { and high workload for } \\
\text { providers. }\end{array}$ \\
\hline $\begin{array}{l}\text { Khader } \\
(2014)(41)\end{array}$ & $\begin{array}{l}\text { Country of } \\
\text { Asylum: } \\
\text { Jordan } \\
\\
\text { Country of } \\
\text { Origin: } \\
\text { Palestinian } \\
\text { Territories }\end{array}$ & EMRO & $\begin{array}{l}\text { Retrospective } \\
\text { cohort study } \\
\text { with program } \\
\text { and outcome } \\
\text { data collected } \\
\text { and analyzed } \\
\text { using E-Health }\end{array}$ & $\begin{array}{l}\text { Palestine refugees living } \\
\text { in Jordan }\end{array}$ & $\begin{array}{l}\text { October } \\
\text { 2009- June } \\
2013\end{array}$ & $\begin{array}{c}18,881 \\
\text { patients }\end{array}$ & $\begin{array}{c}50 \% \text { of patients were } \\
\text { diagnosed with both } \\
\text { hypertension and } \\
\text { diabetes and } 50 \% \text { had } \\
\text { hypertension alone. } \\
\text { There were } \\
\text { significantly more } \\
\text { patients with } \\
\text { hypertension and } \\
\text { diabetes ( } \mathrm{N}=966, \\
13 \% \text { ) who had } \\
\text { disease- related } \\
\text { complications than } \\
\text { patients who had } \\
\text { hypertension alone (N } \\
=472,6 \% \text { ) [OR } 2.2, \\
\text { 95\% CI } 2.0-2.5] . \\
\text { Most common risk } \\
\text { factors included } \\
\text { smoking, physical } \\
\text { inactivity, and obesity. }\end{array}$ \\
\hline $\begin{array}{l}\text { Marjanovic } \\
(2003)(24)\end{array}$ & Croatia & Europe & $\begin{array}{l}\text { Retrospective } \\
\text { chart review }\end{array}$ & $\begin{array}{c}\text { Patients examined at } \\
\text { Beli Manastir Health } \\
\text { Center Department of } \\
\text { Emergency in Baranya, } \\
\text { Croatia post- war }\end{array}$ & $\begin{array}{l}\text { November } \\
1997 \text { (the } \\
\text { time of } \\
\text { Baranya } \\
\text { reintegration } \\
\text { into the } \\
\text { legal system } \\
\text { of the } \\
\text { Republic of } \\
\text { Croatia after } \\
\text { the war) - } \\
\text { December } \\
2001\end{array}$ & $\begin{array}{l}513 \text { stroke } \\
\text { patients }\end{array}$ & $\begin{array}{c}\text { Stroke patients } \\
\text { presenting to the } \\
\text { emergency department } \\
\text { at a single site had an } \\
\text { average of } 68.4 y \text {, with } \\
\text { an age range from } 25- \\
\text { 91y, and a near equal } \\
\text { distribution between } \\
\text { men and women } \\
\text { (51.7\% male). Only } \\
50.6 \% \text { of patients } \\
\text { presented within } 6 \\
\text { hours, another } 16.2 \% \\
\text { presented after } 24 \\
\text { hours. Paresis, speech } \\
\text { impairment and vision } \\
\text { impairment were the } \\
\text { most common } \\
\text { presenting symptoms. } \\
85.8 \% \text { of patients had } \\
\text { hypertension, } 27 \% \text { had } \\
\text { diabetes, } 44.6 \% \text { had } \\
\text { hyperlipidemia and } \\
46 \% \text { also had cardiac } \\
\text { disease. } 38.4 \% \text { of } \\
\text { patients presenting to } \\
\text { the hospital died. }\end{array}$ \\
\hline $\begin{array}{l}\text { Markoglou } \\
(2005)(28)\end{array}$ & Kosovo & Europe & Cross sectional & $\begin{array}{l}\text { Patients under the care } \\
\text { of the NATO forces } \\
\text { who provided medical }\end{array}$ & $\begin{array}{c}\text { January } \\
2000 \text { - July } \\
2000\end{array}$ & 830 patients & $\begin{array}{c}30.6 \% \text { patients were } \\
\text { diagnosed with } \\
\text { hypertension }(188\end{array}$ \\
\hline
\end{tabular}


medRxiv preprint doi: https://doi.org/10.1101/2020.10.15.20213025; this version posted October 20, 2020. The copyright holder for this preprint (which was not certified by peer review) is the author/funder, who has granted medRxiv a license to display the preprint in perpetuity.

All rights reserved. No reuse allowed without permission.

\begin{tabular}{|c|c|c|c|c|c|c|c|}
\hline & $\begin{array}{l}\text { Country/ } \\
\text { Territory of } \\
\text { Interest }\end{array}$ & $\begin{array}{l}\text { WHO } \\
\text { region }\end{array}$ & Type of study & Target Population & $\begin{array}{c}\text { Years of } \\
\text { observation }\end{array}$ & $\begin{array}{c}\text { Number of } \\
\text { study } \\
\text { participants }\end{array}$ & Major findings \\
\hline & & & & $\begin{array}{l}\text { services to the civilians } \\
\text { of Kosovo during the } \\
\text { Yugoslav Wars }\end{array}$ & & & $\begin{array}{c}\text { female and } 66 \text { male), } \\
\text { More than half of the } \\
\text { patients (51.2\%) had } \\
\text { severe hypertension, } \\
31.5 \% \text { modest and } \\
17.3 \% \text { mild. Only } \\
5.5 \% \text { of patients were } \\
\text { on regular } \\
\text { antihypertensive } \\
\text { treatment (9.09\% men } \\
\text { and } 4.24 \% \text { women). } \\
\text { Concomitant diseases } \\
\text { in our patients ( } 62 \% \\
\text { of patients) were in } \\
\text { descending order } \\
\text { by incidence } \\
\text { rheumatic, } \\
\text { cardiovascular and } \\
\text { COPD disorders. } \\
\text { Hypertension } \\
\text { due to increased } \\
\text { sympathetic } \\
\text { activity(attributed to } \\
\text { war stress) was } \\
\text { present in } 35 \text { patients, } \\
\text { (13.78\%, } 32-17.02 \% \\
\text { women and } 3-4.55 \% \\
\text { men, p }<0.05 \text { ), and } \\
\text { hypertension } \\
\text { secondary to the use } \\
\text { of NSAIDs or } \\
\text { cortisone in } \\
15 \text { patients (5.91\%, } 8 \\
\text { women - } 4.26 \% \text { and } 7 \\
\text { men - } 10.6 \%, p>0.1) .\end{array}$ \\
\hline $\begin{array}{c}\text { Mateen } \\
(2012)(30)\end{array}$ & $\begin{array}{l}\text { Country of } \\
\text { Asylum: } \\
\text { Jordan } \\
\text { Country of } \\
\text { Origin: } \\
\text { Iraq }\end{array}$ & EMRO & $\begin{array}{l}\text { Retrospective } \\
\text { Cohort }\end{array}$ & $\begin{array}{l}\text { Iraqi refugees receiving } \\
\text { UNHCR health } \\
\text { assistance in Jordan }\end{array}$ & $\begin{array}{c}\text { January } \\
2010- \\
\text { December } \\
2010\end{array}$ & $\begin{array}{l}7,642 \\
\text { registered } \\
\text { Iraqi } \\
\text { refugees }\end{array}$ & $\begin{array}{c}\text { For adults } 18 y \text { and } \\
\text { older, primary } \\
\text { hypertension was the } \\
\text { top diagnosis(22\%). } \\
\text { Diagnoses requiring } \\
\text { the greatest number of } \\
\text { visits per refugee were } \\
\text { cerebrovascular } \\
\text { disease (average of } \\
1.46 \text { visits per } \\
\text { refugee); senile } \\
\text { cataract (1.46); } \\
\text { glaucoma (1.44); } \\
\text { urolithiasis (1.38); } \\
\text { prostatic } \\
\text { hyperplasia(1.36); and } \\
\text { angina pectoris (1.35). } \\
\text { Concomitant disease } \\
\text { was common (60\% } \\
\text { has more than one } \\
\text { diagnosis). }\end{array}$ \\
\hline $\begin{array}{c}\text { Miric } \\
(2001)(33)\end{array}$ & Croatia & Europe & $\begin{array}{l}\text { Retrospective } \\
\text { chart review }\end{array}$ & $\begin{array}{l}\text { Patients hospitalized in } \\
\text { coronary care units of } \\
\text { Clinical Hospital Split } \\
\text { prior to, during, and } \\
\text { following the Croatian } \\
\text { War of Independence }\end{array}$ & $1989-1997$ & $\begin{array}{c}3,454 \\
\text { patients }\end{array}$ & $\begin{array}{l}\text { In the } 3 \text {-year period } \\
\text { preceding the war, } \\
\text { from } 1989 \text { to } 1991, \\
1,024 \text { patients were } \\
\text { hospitalized because } \\
\text { of MI. During the } 3 \\
\text { years of full war } \\
\text { activities, from } 1992 \\
\text { to } 1994 \text {, there were } \\
1,257 \text { patients } \\
\text { (significantly more; } p\end{array}$ \\
\hline
\end{tabular}


medRxiv preprint doi: https://doi.org/10.1101/2020.10.15.20213025; this version posted October 20, 2020. The copyright holder for this preprint (which was not certified by peer review) is the author/funder, who has granted medRxiv a license to display the preprint in perpetuity.

All rights reserved. No reuse allowed without permission.

\begin{tabular}{|c|c|c|c|c|c|c|c|}
\hline & $\begin{array}{c}\text { Country/ } \\
\text { Territory of } \\
\text { Interest }\end{array}$ & $\begin{array}{l}\text { WHO } \\
\text { region }\end{array}$ & Type of study & Target Population & $\begin{array}{c}\text { Years of } \\
\text { observation }\end{array}$ & $\begin{array}{l}\text { Number of } \\
\text { study } \\
\text { participants }\end{array}$ & Major findings \\
\hline & & & & & & & $\begin{array}{c}<0.05) \text {. And in the } 3- \\
\text { year period after the } \\
\text { war, from } 1995 \text { to } \\
1997, \text { there were } 1,173 \\
\text { patients. Older age } \\
\text { was a risk factor for } \\
\text { greater morbidity and } \\
\text { mortality, however the } \\
\text { number of smokers } \\
\text { was greater among } \\
\text { patients younger than } \\
45 \text { years }(75 \% \text { vs. } \\
51 \% ; \mathrm{p}<0.001) .\end{array}$ \\
\hline $\begin{array}{c}\text { Mousa } \\
(2010)(29)\end{array}$ & $\begin{array}{c}\text { Country of } \\
\text { Asylum: } \\
\text { Jordan, } \\
\text { Lebanon, } \\
\text { Syria, West } \\
\text { Bank/Gaza } \\
\\
\text { Country of } \\
\text { Origin: } \\
\text { Palestinian } \\
\text { Territories }\end{array}$ & EMRO & Case series & $\begin{array}{l}\text { Refugees registered by } \\
\text { the United Nations } \\
\text { Relief and Works } \\
\text { Agency for Palestine } \\
\text { Refugees in the Near } \\
\text { East (UNRWA) }\end{array}$ & June 2007 & $\begin{array}{c}7,762 \\
\text { refugees }\end{array}$ & $\begin{array}{c}\text { Overall } 18.7 \% \text { of the } \\
\text { screened population } \\
\text { presented with high } \\
\text { blood pressure } \geq \\
140 / \geq 90 \mathrm{mmHg} \text { ). } \\
\text { People were referred } \\
\text { for screening most } \\
\text { commonly because of } \\
\text { age (both sexes), } \\
\text { followed by smoking } \\
\text { (males) and family } \\
\text { history (females). } \\
\text { More females over } 40 \\
\text { years of age were } \\
\text { screened than men } \\
\text { (p<0.01). }\end{array}$ \\
\hline $\begin{array}{l}\text { Otoukesh } \\
(2012)(42)\end{array}$ & $\begin{array}{l}\text { Country of } \\
\text { Asylum: } \\
\text { Iran } \\
\text { Country of } \\
\text { Origin: } \\
\text { Afghanistan }\end{array}$ & EMRO & $\begin{array}{l}\text { Retrospective } \\
\text { cross sectional }\end{array}$ & Afghan refugees in Iran & $2005-2010$ & $\begin{array}{c}23,152 \\
\text { refugees }\end{array}$ & $\begin{array}{c}\text { Ischemic heart } \\
\text { diseases constituted } \\
\text { the fourth leading } \\
\text { cause of referrals } \\
\text { (10.4\% of referrals). } \\
\text { Referrals by Pashtun } \\
\text { group were mostly for } \\
\text { neoplasms (17\%), } \\
\text { among Uzbek group it } \\
\text { was nephropathies } \\
\text { (26\%), and in Baluch } \\
\text { group hematopoietic } \\
\text { disorders }(25 \%) .\end{array}$ \\
\hline $\begin{array}{c}\text { Sibai } \\
(2001)(20)\end{array}$ & Lebanon & EMRO & $\begin{array}{l}\text { Retrospective } \\
\text { cohort study }\end{array}$ & $\begin{array}{l}\text { Lebanese aged } 50 \text { years } \\
\text { and over residing in } \\
\text { Beirut, Lebanon in } 1983\end{array}$ & 1983-1993 & 1,567 cases & $\begin{array}{l}\text { The most important } \\
\text { causes were non- } \\
\text { communicable } \\
\text { diseases, mainly } \\
\text { circulatory disease } \\
(60 \%) \text {; and cancer } \\
(15 \%) \text {. Among } \\
\text { circulatory diseases, } \\
\text { ischaemic heart } \\
\text { disease accounted for } \\
\text { the majority of the } \\
\text { mortality burden } \\
\text { (68\%) followed by } \\
\text { cerebrovascular } \\
\text { diseases ( } 21 \%) \text {. In } \\
\text { countries that lack } \\
\text { reliable sources of } \\
\text { mortality data, the } \\
\text { utility of verbal } \\
\text { autopsy can be viably } \\
\text { extended to cohort } \\
\text { studies for assessing } \\
\text { causes of death. }\end{array}$ \\
\hline Sibai & Lebanon & EMRO & Retrospective & Lebanese aged 50 years & 1984-1994 & & Most important causes \\
\hline
\end{tabular}


medRxiv preprint doi: https://doi.org/10.1101/2020.10.15.20213025; this version posted October 20, 2020. The copyright holder for this preprint (which was not certified by peer review) is the author/funder, who has granted medRxiv a license to display the preprint in perpetuity. All rights reserved. No reuse allowed without permission.

\begin{tabular}{|c|c|c|c|c|c|c|c|}
\hline & $\begin{array}{c}\text { Country/ } \\
\text { Territory of } \\
\text { Interest }\end{array}$ & $\begin{array}{c}\text { WHO } \\
\text { region }\end{array}$ & Type of study & Target Population & $\begin{array}{c}\text { Years of } \\
\text { observation }\end{array}$ & $\begin{array}{l}\text { Number of } \\
\text { study } \\
\text { participants }\end{array}$ & Major findings \\
\hline $\begin{array}{c}(2007) \\
(122)\end{array}$ & & & cohort study & $\begin{array}{l}\text { and over residing in } \\
\text { Beirut, Lebanon }\end{array}$ & & 1,567 cases & $\begin{array}{l}\text { of death were CVD } \\
\text { and Cancer. High } \\
\text { adjusted risk of CVD } \\
\text { mortality associated } \\
\text { with being single } \\
\text { (never-married) versus } \\
\text { married among men } \\
\text { and women. Outcomes } \\
\text { were self-reported. }\end{array}$ \\
\hline $\begin{array}{c}\text { Strong } \\
(2015)(21)\end{array}$ & $\begin{array}{l}\text { Country of } \\
\text { Asylum: } \\
\text { Lebanon } \\
\text { Country of } \\
\text { Origin: } \\
\text { Syria }\end{array}$ & EMRO & Cross sectional & $\begin{array}{l}\text { Syrian refugees over age } \\
60 \text { residing in Lebanon } \\
\text { and registered with } \\
\text { either Caritas Lebanon } \\
\text { Migrant Center (CLMC) } \\
\text { or the Palestinian } \\
\text { Women's Humanitarian } \\
\text { Organization } \\
\text { (PALWHO) }\end{array}$ & $\begin{array}{c}\text { March } 2011 \\
\text { - March } \\
2013\end{array}$ & 210 refugees & $\begin{array}{c}\text { Older refugees } \\
\text { reported a high burden } \\
\text { of chronic illnesses } \\
\text { and disabilities. } \\
\text { Hypertension was } \\
\text { most common (60\%), } \\
\text { followed by diabetes } \\
\text { mellitus (47\%), and } \\
\text { heart disease (30\%). } \\
\text { The burden from these } \\
\text { diseases was } \\
\text { significantly higher in } \\
\text { older Palestinians } \\
\text { compared to older } \\
\text { Syrians, even when } \\
\text { controlling for the } \\
\text { effects of sex and age } \\
\text { (hypertension p < } \\
0.001 ; \text { diabetes p < } \\
0.001 \text {; heart disease } \\
\text { p=0.042). Financial } \\
\text { difficulties were given } \\
\text { as the primary reason } \\
\text { for not seeking care by } \\
79 \% \text { of older refugees. }\end{array}$ \\
\hline $\begin{array}{c}\text { Sun } \\
(2013)(27)\end{array}$ & China & $\begin{array}{l}\text { Western } \\
\text { Pacific }\end{array}$ & Cross sectional & $\begin{array}{l}\text { Survivors of Wenchuan } \\
\text { earthquake staying in a } \\
\text { temporary shelter for } \\
\text { more than } 1 \text { year }\end{array}$ & $\begin{array}{l}\text { March-May } \\
\quad 2009\end{array}$ & 3,230 adults & $\begin{array}{c}\text { The prevalence rate of } \\
\text { hypertension among } \\
\text { survivors was } 24.08 \% \text {. } \\
\text { Age, family history of } \\
\text { hypertension, sleep } \\
\text { quality, waist-to-hip } \\
\text { ratio, BMI,and blood } \\
\text { glucose levels are risk } \\
\text { factors for earthquake- } \\
\text { induced hypertension. } \\
\text { Mental stress was not } \\
\text { a risk factor. The rates } \\
\text { of hypertension } \\
\text { awareness, dosing, } \\
\text { and control was } \\
34.58 \%, 53.43 \% \text { and } \\
17.84 \%, \text { respectively. }\end{array}$ \\
\hline $\begin{array}{c}\text { Tomic } \\
(2009)(43)\end{array}$ & $\begin{array}{l}\text { Bosnia and } \\
\text { Herzegovina }\end{array}$ & Europe & $\begin{array}{l}\text { Retrospective } \\
\text { case control }\end{array}$ & $\begin{array}{l}\text { Pregnant women with } \\
\text { hypertensive disorders } \\
\text { and their neonates } \\
\text { hospitalized in the } \\
\text { Obstetric/Gynecological } \\
\text { and Pediatric } \\
\text { Departments of Mostar } \\
\text { Hospital during the war } \\
\text { and postwar period } \\
\text { (Bosnian War 1992- } \\
\text { 1995) }\end{array}$ & $\begin{array}{l}\text { January } \\
1995- \\
\text { December } \\
1999\end{array}$ & $\begin{array}{c}542 \\
\text { pregnancies } \\
\text { with } \\
\text { hypertensive } \\
\text { disorders }\end{array}$ & $\begin{array}{l}\text { The prevalence of } \\
\text { hypertensive disorders } \\
\text { in pregnancy was } \\
\text { higher during wartime, } \\
\text { demonstrated by a } \\
\text { drop in prevalence } \\
\text { during the five years } \\
\text { after the war, with the } \\
\text { highest prevalence } \\
\text { occurring at } 8.7 \% \\
\text { during the first year } \\
\text { after the war. Those in } \\
\text { the study group had } \\
\text { higher odds of } \\
\text { placental abruption, } \\
\text { cesarean delivery, }\end{array}$ \\
\hline
\end{tabular}


medRxiv preprint doi: https://doi.org/10.1101/2020.10.15.20213025; this version posted October 20, 2020. The copyright holder for this preprint (which was not certified by peer review) is the author/funder, who has granted medRxiv a license to display the preprint in perpetuity. All rights reserved. No reuse allowed without permission.

\begin{tabular}{|c|c|c|c|c|c|c|c|}
\hline & $\begin{array}{c}\text { Country/ } \\
\text { Territory of } \\
\text { Interest } \\
\end{array}$ & $\begin{array}{l}\text { WHO } \\
\text { region }\end{array}$ & Type of study & Target Population & $\begin{array}{c}\text { Years of } \\
\text { observation }\end{array}$ & $\begin{array}{c}\text { Number of } \\
\text { study } \\
\text { participants }\end{array}$ & Major findings \\
\hline & & & & & & & $\begin{array}{l}\text { preterm birth, fetal } \\
\text { growth restriction, and } \\
\text { fetal death. Those in } \\
\text { the study group with } \\
\text { hypertensive } \\
\text { pregnancy disorders } \\
\text { had a lower number of } \\
\text { prenatal care visits } \\
\text { than controls } \\
(\mathrm{p}<0.001) .\end{array}$ \\
\hline $\begin{array}{c}\text { Vasilj } \\
(2006)(31)\end{array}$ & $\begin{array}{c}\text { Bosnia and } \\
\text { Herzegovina }\end{array}$ & Europe & $\begin{array}{l}\text { Retrospective } \\
\text { chart review }\end{array}$ & $\begin{array}{l}\text { Patients who suffered } \\
\text { from the acute coronary } \\
\text { syndrome in western } \\
\text { Herzegovina pre, } \\
\text { during, and post-war } \\
\text { (Bosnian War 1992- } \\
\text { 1995) }\end{array}$ & $1987-2001$ & $\begin{array}{c}2,022 \\
\text { patients }\end{array}$ & $\begin{array}{l}\text { There was a higher } \\
\text { prevalence of ACS } \\
\text { presentations both } \\
\text { during ( } \mathrm{n}=665, \mathrm{p}< \\
0.0005) \text { and after the } \\
\text { war ( } \mathrm{n}=843, \mathrm{p}< \\
0.0005) \text {, as compared } \\
\text { to prior to the war } \\
(\mathrm{n}=365) \text { in both sexes. }\end{array}$ \\
\hline $\begin{array}{l}\text { Vukovic } \\
(2005)(36)\end{array}$ & Serbia & Europe & $\begin{array}{l}\text { Retrospective } \\
\text { chart review }\end{array}$ & $\begin{array}{c}\text { Patients with ischemic } \\
\text { heart disease who were } \\
\text { admitted to the Cardiac } \\
\text { policlinic for a control } \\
\text { check-up immediately } \\
\text { after the suspension of } \\
\text { air raids }\end{array}$ & June 1999 & 75 patients & $\begin{array}{l}\text { The severity of angina } \\
\text { pains and } \\
\text { nitroglycerin pill } \\
\text { usage was associated } \\
\text { with timing of air } \\
\text { raids, increasing } \\
\text { during the first week } \\
\text { and initial week after } \\
\text { raids when compared } \\
\text { to the week before } \\
\text { raids. }\end{array}$ \\
\hline $\begin{array}{c}\text { Yusef } \\
(2000)(22)\end{array}$ & $\begin{array}{l}\text { Country of } \\
\text { Asylum: } \\
\text { Lebanon } \\
\text { Country of } \\
\text { Origin: } \\
\text { Palestinian } \\
\text { Territories }\end{array}$ & EMRO & Cross-sectional & $\begin{array}{l}\text { Diabetic and } \\
\text { hypertensive patients } \\
\text { attending UNRWA } \\
\text { primary health care } \\
\text { facilities in Lebanon }\end{array}$ & 1997 & $\begin{array}{l}2,202 \\
\text { records }\end{array}$ & $\begin{array}{c}\text { Presence of both } \\
\text { diabetes and } \\
\text { hypertension increased } \\
\text { the risk for late-stage } \\
\text { complications. The } \\
\text { major complication } \\
\text { was cardiovascular } \\
\text { disease followed by } \\
\text { retinopathy. Only } \\
18.2 \% \text { of diabetic } \\
\text { patients and } 17.7 \% \text { of } \\
\text { diabetic patients with } \\
\text { hypertension were } \\
\text { managed by lifestyle } \\
\text { modification. } \\
\text { Medication shortages } \\
\text { may drive medication } \\
\text { choices for } \\
\text { hypertension. }\end{array}$ \\
\hline $\begin{array}{l}\text { Zubaid } \\
(2006)(39)\end{array}$ & Kuwait & EMRO & $\begin{array}{l}\text { Retrospective } \\
\text { chart review }\end{array}$ & $\begin{array}{c}\text { Catchment area of } \\
\text { Mubarak Al Kabeer } \\
\text { Hospital }\end{array}$ & March 2003 & $\begin{array}{l}1 \text { Missile } \\
\text { Attack } \\
\text { Period } \\
\text { (MAP) and } \\
4 \text { control } \\
\text { periods }\end{array}$ & $\begin{array}{c}\text { Missile attacks were } \\
\text { associated with an } \\
\text { increase in the } \\
\text { incidence of AMI. The } \\
\text { number of admissions } \\
\text { for AMI was highest } \\
\text { during MAP, } 21 \text { cases } \\
\text { compared to } 14-16 \\
\text { cases in the four } \\
\text { control periods, with a } \\
\text { trend towards increase } \\
\text { during MAP } \\
\text { (incidence rate } \\
\text { ratio=1.59; } 95 \% \text { CI } \\
0.95 \text { to } 2.66, \\
\text { p }<0.07 \text { ). The number } \\
\text { of admissions for AMI } \\
\text { during the first } 5 \text { days }\end{array}$ \\
\hline
\end{tabular}


medRxiv preprint doi: https://doi.org/10.1101/2020.10.15.20213025; this version posted October 20, 2020. The copyright holder for this preprint (which was not certified by peer review) is the author/funder, who has granted medRxiv a license to display the preprint in perpetuity. All rights reserved. No reuse allowed without permission.

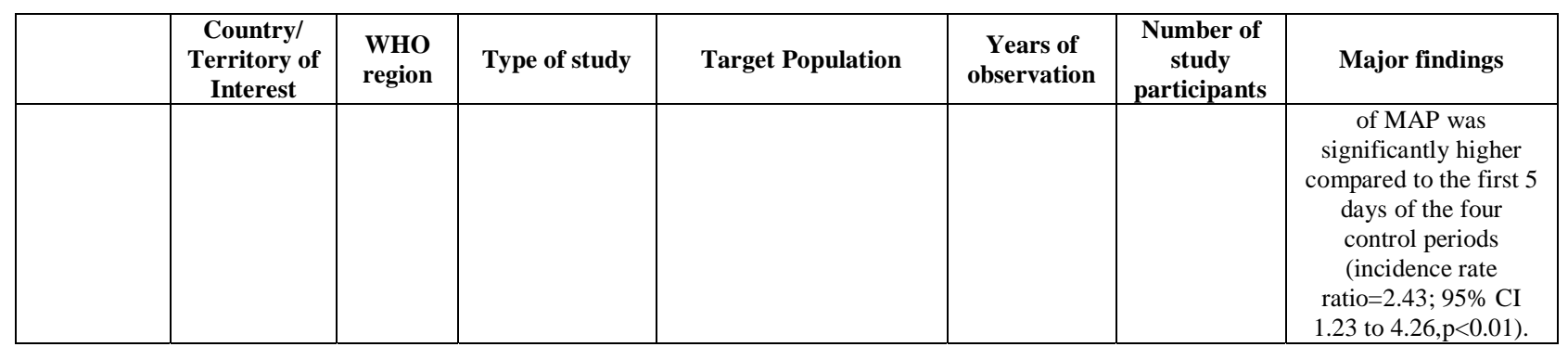

Table 2: Characteristics of included publications by disease type: Cancer

\begin{tabular}{|c|c|c|c|c|c|c|c|}
\hline & $\begin{array}{l}\text { Country/ } \\
\text { Territory of } \\
\text { Interest }\end{array}$ & $\begin{array}{l}\text { WHO } \\
\text { region }\end{array}$ & $\begin{array}{l}\text { Type of } \\
\text { study }\end{array}$ & $\begin{array}{c}\text { Target } \\
\text { Population }\end{array}$ & $\begin{array}{c}\text { Years of } \\
\text { observation }\end{array}$ & $\begin{array}{l}\text { Number of } \\
\text { study } \\
\text { participants }\end{array}$ & Major findings \\
\hline $\begin{array}{l}\text { Huynh } \\
(2004)(53)\end{array}$ & Vietnam & $\begin{array}{l}\text { Western } \\
\text { Pacific }\end{array}$ & Case control & $\begin{array}{l}\text { Vietnamese } \\
\text { women } \\
\text { hospitalized with } \\
\text { cervical cancer }\end{array}$ & $\begin{array}{c}\text { June } 1996 \text { - } \\
\text { September } \\
1996\end{array}$ & $\begin{array}{l}145 \text { women in } \\
\text { southern } \\
\text { Vietnam and } \\
80 \text { women in } \\
\text { northern } \\
\text { Vietnam }\end{array}$ & $\begin{array}{l}\text { The development of } \\
\text { invasive cervical } \\
\text { cancer was } \\
\text { significantly } \\
\text { associated with } \\
\text { military service by } \\
\text { husbands during the } \\
\text { Second Indochinese } \\
\text { War and with parity } \\
\text { status. Geographic } \\
\text { and temporal } \\
\text { variation in cervical } \\
\text { cancer rates among } \\
\text { Vietnamese women } \\
\text { was associated with } \\
\text { the movement of } \\
\text { soldiers. }\end{array}$ \\
\hline $\begin{array}{c}\text { Khan } \\
(1997)(55)\end{array}$ & $\begin{array}{c}\text { Country of } \\
\text { Asylum: Pakistan } \\
\text { Country of Origin: } \\
\text { Afghanistan }\end{array}$ & EMRO & $\begin{array}{c}\text { Cross } \\
\text { sectional }\end{array}$ & $\begin{array}{l}\text { Patients from } \\
\text { North West } \\
\text { Pakistan and } \\
\text { Afghan refugees } \\
\text { attending the } \\
\text { Institute of } \\
\text { Radiotherapy } \\
\text { and Nuclear } \\
\text { Medicine, } \\
\text { Peshwar }\end{array}$ & $1990-1994$ & $\begin{array}{c}13,359 \\
\text { patients } \\
2988 \text { were } \\
\text { Afghan } \\
\text { refugees } \\
\text { 10,371 were } \\
\text { adults from } \\
\text { North West of } \\
\text { Pakistan }\end{array}$ & $\begin{array}{l}\text { In male Afghan } \\
\text { refugees, esophageal } \\
\text { cancer represented } \\
16.6 \% \text { of the cases, } \\
\text { compared to only } \\
4.6 \% \text { of the cases in } \\
\text { Pakistani residents. } \\
\text { Both Pakistani and } \\
\text { Afghani refugee } \\
\text { women experienced } \\
\text { breast cancer as the } \\
\text { most common cancer. }\end{array}$ \\
\hline $\mathrm{Li}(2012)(50)$ & China & $\begin{array}{l}\text { Western } \\
\text { Pacific }\end{array}$ & $\begin{array}{l}\text { Retrospective } \\
\text { cohort }\end{array}$ & $\begin{array}{l}\text { Birth cohorts } \\
\text { who were } \\
\text { exposed to the } \\
\text { 1959-1961 } \\
\text { Chinese famine }\end{array}$ & 1970-2009 & $\begin{array}{c}\text { Population of } \\
\text { Zhaoyuan } \\
\text { county } \\
\text { during the } \\
1970-1974 \\
\text { death survey } \\
\text { and 2,830,866 } \\
\text { during the } \\
\text { 2005-2009 } \\
\text { death survey. }\end{array}$ & $\begin{array}{l}\text { The Zhaoyuan } \\
\text { population, which } \\
\text { experienced long- } \\
\text { term nutritional } \\
\text { deficiencies from } \\
\text { childhood to } \\
\text { adolescence, had } \\
\text { increased risk for } \\
\text { stomach cancer } 15 \text { to } \\
20 \square \text { years after the } \\
\text { 1959-1961 Chinese } \\
\text { famine. The birth } \\
\text { cohorts who were } \\
\text { exposed to famine or } \\
\text { experienced } \\
\text { malnutrition had } \\
\text { higher stomach } \\
\text { cancer mortality rates } \\
\text { in later life than the }\end{array}$ \\
\hline
\end{tabular}




\begin{tabular}{|c|c|c|c|c|c|c|c|}
\hline & & & & & & & $\begin{array}{l}\text { birth cohorts not } \\
\text { exposed to } \\
\text { malnutrition }\end{array}$ \\
\hline $\begin{array}{c}\text { Marom } \\
(2014)(45)\end{array}$ & Philippines & $\begin{array}{l}\text { Western } \\
\text { Pacific }\end{array}$ & Case series & $\begin{array}{l}\text { Patients } \\
\text { presenting with } \\
\text { head and neck } \\
\text { (H\&N) tumors to } \\
\text { a field hospital in } \\
\text { the 'sub-acute' } \\
\text { period following } \\
\text { a typhoon. }\end{array}$ & $\begin{array}{c}\text { November } \\
2013\end{array}$ & $\begin{array}{c}1844 \text { adult } \\
\text { patients } \\
\text { examined, } 85 \\
(5 \%) \\
\text { presented } \\
\text { with H\&N } \\
\text { tumors }\end{array}$ & $\begin{array}{l}\text { In a relief mission, } \\
\text { despite the lack of } \\
\text { clinical and } \\
\text { pathological staging } \\
\text { and questionable } \\
\text { continuity of care, } \\
\text { surgical interventions } \\
\text { can be considered for } \\
\text { therapeutic, palliative } \\
\text { and diagnostic } \\
\text { purposes }\end{array}$ \\
\hline $\begin{array}{l}\text { McKenzie } \\
(2015)(48)\end{array}$ & $\begin{array}{c}\text { Country of } \\
\text { Asylum: } \\
\text { Jordan } \\
\text { Country of Origin: } \\
\text { Iraq, Syria }\end{array}$ & EMRO & $\begin{array}{l}\text { Retrospective } \\
\text { cohort }\end{array}$ & $\begin{array}{l}\text { UNHCR } \\
\text { registered } \\
\text { refugees } \\
\text { (Iraqi/Syrian) in } \\
\text { Jordan }\end{array}$ & $2012-2013$ & 223 refugees & $\begin{array}{c}\text { Brain tumors } \\
\text { accounted for 13\% } \\
\text { (n=29) of } \\
\text { neuropsychiatric } \\
\text { applications, and was } \\
\text { the most expensive } \\
\text { neuropsychiatric } \\
\text { diagnosis overall and } \\
\text { per applicant. The } \\
\text { ECC denied six } \\
\text { applications for } \\
\text { reasons of } \\
\text { eligibility, cost, } \\
\text { and/or prognosis. Of } \\
\text { the } 20 \text { approved } \\
\text { applications, 15\% } \\
\text { (n=3) were approved } \\
\text { for less } \\
\text { than the requested } \\
\text { amount, receiving on } \\
\text { average } 39 \% \text { of } \\
\text { requested funds. }\end{array}$ \\
\hline $\begin{array}{l}\text { Milojkovic } \\
(2005)(51)\end{array}$ & Croatia & Europe & $\begin{array}{l}\text { Retrospective } \\
\text { cohort }\end{array}$ & $\begin{array}{l}\text { Patients with } \\
\text { corpus uteri and } \\
\text { cervix uteri } \\
\text { cancer and } \\
\text { ovarian cancer } \\
\text { treated in the } \\
\text { Clinical Hospital } \\
\text { Osijek }\end{array}$ & $1984-2002$ & $\begin{array}{l}1455 \text { patients } \\
\text { treated for } \\
\text { gynecological } \\
\text { cancer were } \\
\text { analyzed. }\end{array}$ & $\begin{array}{l}\text { Gynecologic cancer } \\
\text { incidence according } \\
\text { to age shows an } \\
\text { increase tendency of } \\
\text { cervical cancer in } \\
\text { younger women in the } \\
\text { post war period. The } \\
\text { incidence of corpus } \\
\text { cancer and ovary has } \\
\text { not changed in the } \\
\text { observed periods }\end{array}$ \\
\hline $\begin{array}{l}\text { Otoukesh } \\
(2012)(42)\end{array}$ & $\begin{array}{c}\text { Country of } \\
\text { Asylum: Iran } \\
\text { Country of Origin: } \\
\text { Afghanistan }\end{array}$ & EMRO & $\begin{array}{c}\text { Cross } \\
\text { sectional }\end{array}$ & $\begin{array}{l}\text { Afghan refugees } \\
\text { in Iran }\end{array}$ & 2005-2010 & $\begin{array}{c}23,152 \\
\text { refugees }\end{array}$ & $\begin{array}{l}\text { Neoplasms } \\
\text { represented } 17 \% \text { of } \\
\text { referrals among } \\
\text { Pashtun group }\end{array}$ \\
\hline $\begin{array}{l}\text { Shamseddine } \\
(2004)(49)\end{array}$ & Lebanon & EMRO & $\begin{array}{l}\text { Ecological } \\
\text { study }\end{array}$ & $\begin{array}{l}\text { Lebanese cancer } \\
\text { patients } \\
\text { following the } \\
1975-1990 \\
\text { Lebanese Civil } \\
\text { War }\end{array}$ & 1998 & 4388 cases & $\begin{array}{l}\text { Among males, the } \\
\text { most frequently } \\
\text { reported cancer was } \\
\text { bladder }(18.5 \%), \\
\text { followed by prostate } \\
(14.2 \%) \text {, and lung } \\
\text { cancer }(14.1 \%) \text {. In } \\
\text { sharp contrast to } \\
\text { countries worldwide, } \\
\text { bladder cancer was } \\
\text { notably high, in } \\
\text { particular among } \\
\text { males. Among } \\
\text { females, breast cancer } \\
\text { alone constituted } \\
\text { around one third of }\end{array}$ \\
\hline
\end{tabular}




\begin{tabular}{|c|c|c|c|c|c|c|c|}
\hline & & & & & & & $\begin{array}{l}\text { the total cancer } \\
\text { caseload in the } \\
\text { country. This was } \\
\text { followed by colon } \\
\text { cancer }(5.8 \%) \text {, and } \\
\text { cancer of the corpus } \\
\text { uteri }(4.8 \%) \text {. The } \\
\text { predominance of } \\
\text { smoking related } \\
\text { cancers highlights the } \\
\text { importance of } \\
\text { primary preventive } \\
\text { strategies aimed at } \\
\text { reducing smoking } \\
\text { prevalence in } \\
\text { Lebanon. }\end{array}$ \\
\hline $\begin{array}{c}\text { Sibai } \\
(2001)(20)\end{array}$ & Lebanon & EMRO & $\begin{array}{l}\text { Retrospective } \\
\text { cohort }\end{array}$ & $\begin{array}{l}\text { Retrospective } \\
\text { cohort study } \\
\text { Lebanese aged } \\
50 \text { years and } \\
\text { over residing in } \\
\text { Beirut, Lebanon } \\
\text { in 1983-1993 } \\
\text { during the } \\
\text { Lebanese Civil } \\
\text { War }\end{array}$ & $1983-1993$ & 1567 cases & $\begin{array}{l}\text { In both sexes, the } \\
\text { leading causes of } \\
\text { death were non- } \\
\text { communicable, } \\
\text { mainly circulatory } \\
\text { diseases }(60 \%) \text { and } \\
\text { cancer }(15 \%) \text {. }\end{array}$ \\
\hline $\begin{array}{l}\text { Telarovic } \\
(2006)(52)\end{array}$ & Croatia & Europe & $\begin{array}{c}\text { Cross } \\
\text { sectional }\end{array}$ & $\begin{array}{l}\text { Patients with } \\
\text { CNS tumors } \\
\text { admitted to the } \\
\text { Department of } \\
\text { Neurology of } \\
\text { Pula General } \\
\text { Hospital, Croatia } \\
\text { during wartime }\end{array}$ & $\begin{array}{c}\text { January } \\
1986- \\
\text { December } \\
2000\end{array}$ & 364 patients & $\begin{array}{c}\text { There was a } \\
\text { statistically } \\
\text { significant increase of } \\
\text { incidence rate ratios } \\
\text { (IRR) of CNS tumors } \\
\text { in war period versus } \\
\text { the periods before and } \\
\text { after war. .Higher } \\
\text { proportion of } \\
\text { metastatic tumors } \\
\text { than expected per the } \\
\text { authors literature } \\
\text { review. Authors relate } \\
\text { to stress and PTSD }\end{array}$ \\
\hline
\end{tabular}

Table 3: Characteristics of included publications by disease type: Chronic Respiratory Disease

\begin{tabular}{|c|c|c|c|c|c|c|c|}
\hline & $\begin{array}{c}\text { Country/Territory } \\
\text { of Interest }\end{array}$ & $\begin{array}{l}\text { WHO } \\
\text { region }\end{array}$ & $\begin{array}{l}\text { Type of } \\
\text { study }\end{array}$ & $\begin{array}{c}\text { Target } \\
\text { Population }\end{array}$ & $\begin{array}{c}\text { Years of } \\
\text { observation }\end{array}$ & $\begin{array}{l}\text { Number of } \\
\text { study } \\
\text { participants }\end{array}$ & Major findings \\
\hline $\begin{array}{c}\text { Abul } \\
(2001)(57)\end{array}$ & Kuwait & EMRO & $\begin{array}{l}\text { Retrospective } \\
\text { chart review }\end{array}$ & $\begin{array}{c}\text { Patients } \\
\text { admitted with } \\
\text { asthma in } \\
\text { Kuwait }\end{array}$ & 2001 & $\begin{array}{c}12,113 \\
\text { asthma } \\
\text { patients } \\
\text { during the } \\
\text { pre-Gulf } \\
\text { War period } \\
\text { compared } \\
\text { with } 9,771 \\
\text { patients } \\
\text { during the } \\
\text { post-Gulf } \\
\text { War period }\end{array}$ & $\begin{array}{c}\text { No significant } \\
\text { difference between } \\
\text { hospitalization or } \\
\text { death rates pre and } \\
\text { post Gulf War. }\end{array}$ \\
\hline
\end{tabular}


medRxiv preprint doi: https://doi.org/10.1101/2020.10.15.20213025; this version posted October 20, 2020. The copyright holder for this preprint (which was not certified by peer review) is the author/funder, who has granted medRxiv a license to display the preprint in perpetuity.

All rights reserved. No reuse allowed without permission.

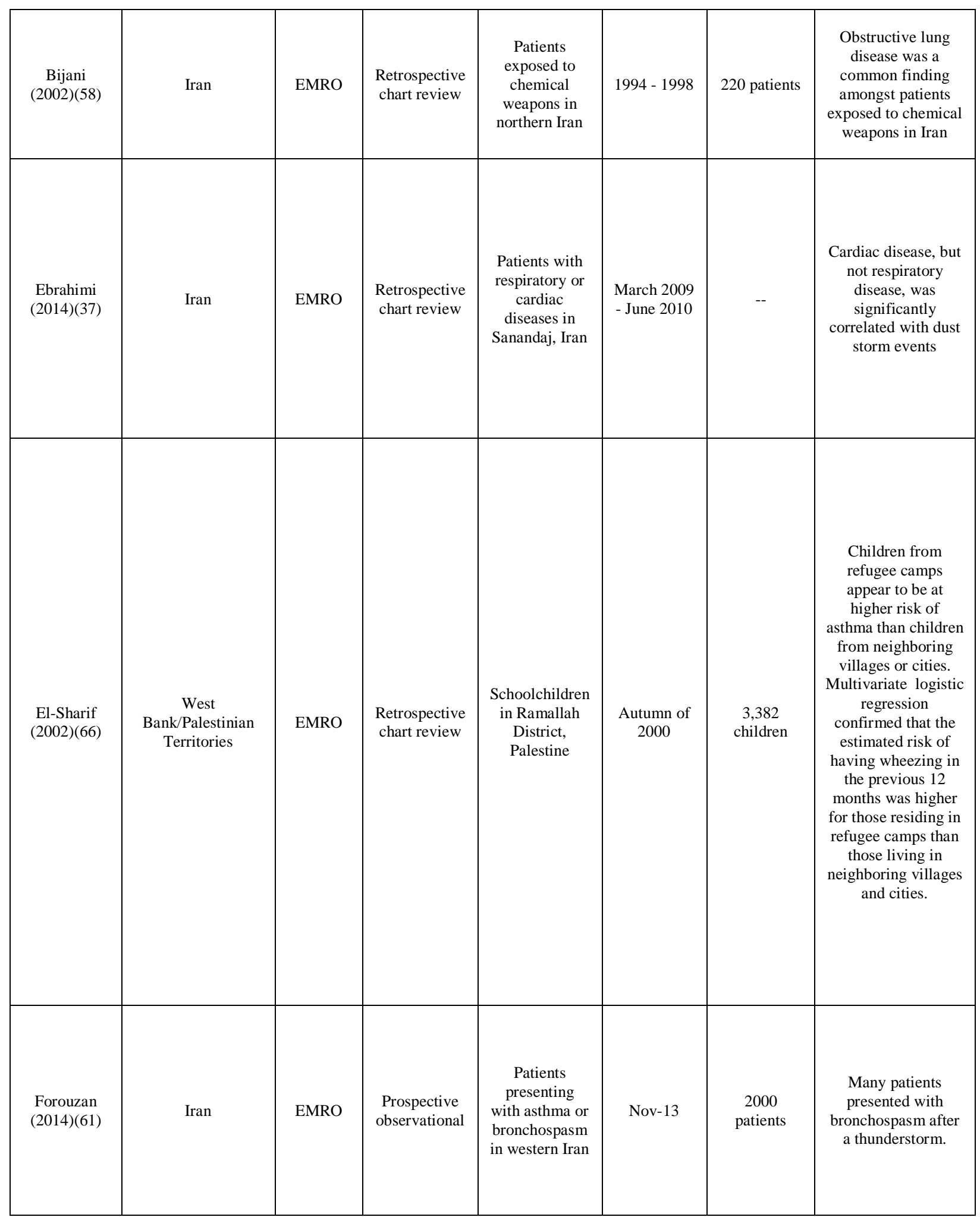




\begin{tabular}{|c|c|c|c|c|c|c|c|}
\hline $\begin{array}{c}\text { Hung } \\
(2013)(26)\end{array}$ & China & $\begin{array}{c}\text { Western } \\
\text { Pacific }\end{array}$ & $\begin{array}{c}\text { Cross- } \\
\text { sectional } \\
\text { chart review }\end{array}$ & $\begin{array}{l}\text { Patients } \\
\text { presenting } \\
\text { during } 19 \text { days } \\
\text { following the } \\
\text { Sichuan } \\
\text { earthquake }\end{array}$ & Jun-08 & $\begin{array}{c}2,034 \\
\text { patients }\end{array}$ & $\begin{array}{c}\text { Musculoskeletal, } \\
\text { respiratory, and GI } \\
\text { problems were the } \\
\text { top } 3 \text { areas and } \\
>43 \% \text { of patients } \\
\text { had BP in HTN } \\
\text { range }\end{array}$ \\
\hline $\begin{array}{c}\text { Kunii } \\
(2002)(62)\end{array}$ & Indonesia & $\begin{array}{l}\text { South- } \\
\text { East Asia }\end{array}$ & $\begin{array}{c}\text { Cross } \\
\text { sectional }\end{array}$ & $\begin{array}{l}\text { Patients } \\
\text { exposed to air } \\
\text { pollution in the } \\
\text { "haze disaster" } \\
\text { in Indonesia }\end{array}$ & $\begin{array}{c}\text { September } \\
1997 \text { - } \\
\text { October } \\
1997\end{array}$ & 543 subjects & $\begin{array}{l}\text { Patients had } \\
\text { increased respiratory } \\
\text { issues after a large } \\
\text { forest fire disaster, } \\
\text { especially the } \\
\text { elderly. Wearing a } \\
\text { high quality face } \\
\text { mask was protective } \\
\text { (vs handkerchief or } \\
\text { simple surgical } \\
\text { mask) }\end{array}$ \\
\hline $\begin{array}{c}\text { Lari } \\
(2014)(60)\end{array}$ & Iran & EMRO & $\begin{array}{c}\text { Cross } \\
\text { sectional }\end{array}$ & $\begin{array}{l}\text { Patients } \\
\text { exposed to } \\
\text { sulphur } \\
\text { mustard gas }\end{array}$ & $\begin{array}{c}\text { March } \\
\text { 2010- April } \\
2011\end{array}$ & 82 patients & $\begin{array}{l}\text { The COPD } \\
\text { Assessment Test } \\
\text { (CAT) was found to } \\
\text { be a valid tool for } \\
\text { assessment of health } \\
\text { related quality of } \\
\text { life in chemical } \\
\text { warfare patients } \\
\text { with COPD }\end{array}$ \\
\hline $\begin{array}{l}\text { Mirsadraee } \\
(2011)(59)\end{array}$ & Iran & EMRO & $\begin{array}{c}\text { Retrospective } \\
\text { Cohort }\end{array}$ & $\begin{array}{l}\text { Patients whose } \\
\text { parents were } \\
\text { exposed to } \\
\text { chemical } \\
\text { warfare }\end{array}$ & -- & 409 children & $\begin{array}{l}\text { The prevalence of } \\
\text { asthma was not } \\
\text { significantly } \\
\text { different in the } \\
\text { offspring of } \\
\text { chemical warfare } \\
\text { victims. }\end{array}$ \\
\hline & & & & & & & \\
\hline
\end{tabular}




\begin{tabular}{|c|c|c|c|c|c|c|c|}
\hline $\begin{array}{c}\text { Molla } \\
(2014)(67)\end{array}$ & Bangladesh & $\begin{array}{l}\text { South- } \\
\text { East Asia }\end{array}$ & $\begin{array}{c}\text { Cross } \\
\text { sectional }\end{array}$ & $\begin{array}{l}\text { Children } 5 \\
\text { years of age in } \\
\text { Dhaka with } \\
\text { diarrhea and } \\
\text { asthma }\end{array}$ & $\begin{array}{c}\text { September } \\
2012 \text { - } \\
\text { November } \\
2012\end{array}$ & $\begin{array}{c}410 \\
\text { households }\end{array}$ & $\begin{array}{l}\text { The DALYs lost due } \\
\text { to asthma and } \\
\text { diarrhea were } \\
\text { significantly } \\
\text { different amongst } \\
\text { the climate refugee } \\
\text { community than a } \\
\text { non refugee group }\end{array}$ \\
\hline $\begin{array}{l}\text { Naumova } \\
(2007)(63)\end{array}$ & Ecuador & Americas & $\begin{array}{c}\text { Cross } \\
\text { sectional } \\
\text { chart review }\end{array}$ & $\begin{array}{l}\text { ED patients } \\
\text { after a volcanic } \\
\text { eruption in } \\
\text { Quito, Ecuador }\end{array}$ & $\begin{array}{c}\text { January } \\
2000 \text { - } \\
\text { December } \\
2000\end{array}$ & $\begin{array}{c}5,169 \\
\text { patients }\end{array}$ & $\begin{array}{l}\text { Rate of ED visits for } \\
\text { respiratory } \\
\text { conditions } \\
\text { significantly } \\
\text { increased in } 3 \text { weeks } \\
\text { after eruption. Rates } \\
\text { of asthma and } \\
\text { asthma related } \\
\text { diagnosis double } \\
\text { during volcano } \\
\text { "fumarolic activity". } \\
345 \text { excess ED visits } \\
\text { in } 4 \text { weeks. }\end{array}$ \\
\hline $\begin{array}{c}\text { Guha- } \\
\text { Sapir(2007) } \\
\text { (64) }\end{array}$ & Indonesia & $\begin{array}{c}\text { South } \\
\text { East Asia }\end{array}$ & $\begin{array}{c}\text { Cross } \\
\text { sectional }\end{array}$ & $\begin{array}{c}\text { Patients } \\
\text { attending an } \\
\text { International } \\
\text { Committee of } \\
\text { the Red } \\
\text { Cross(ICRC) } \\
\text { field hospital } \\
\text { in Aceh, } \\
\text { Indonesia, } \\
\text { established } \\
\text { immediately } \\
\text { after the } \\
\text { tsunami in } \\
2004\end{array}$ & $\begin{array}{c}2 \text { January } \\
15,2004- \\
\text { January } 31 \\
2004005- \\
2010\end{array}$ & $\begin{array}{l}1,188 \text { study } \\
\text { participants }\end{array}$ & $\begin{array}{l}\text { Post tsunami, } \\
\text { respiratory diseases } \\
\text { were one of the most } \\
\text { commonly recorded } \\
\text { conditions }(21.0 \%) \\
\text { and included acute } \\
\text { asthma } \\
\text { exacerbations. }\end{array}$ \\
\hline $\begin{array}{c}\text { Redwood- } \\
\text { Campbell } \\
(2006)(65)\end{array}$ & Indonesia & $\begin{array}{l}\text { South- } \\
\text { East Asia }\end{array}$ & $\begin{array}{c}\text { Cross } \\
\text { Sectional }\end{array}$ & $\begin{array}{l}\text { Patients } \\
\text { registering in } \\
\text { the ICRC field } \\
\text { hospital in } \\
\text { Banda Aceh } \\
\text { after the } \\
\text { tsunami }\end{array}$ & Mar-05 & 271 patients & $\begin{array}{l}12 \% \text { of the problems } \\
\text { seen in the clinic } 9 \\
\text { weeks after the } \\
\text { tsunami were still } \\
\text { directly related to } \\
\text { the tsunami. } \\
\text { Majority of patients } \\
\text { were male, the } \\
\text { problems were } \\
\text { urologic, digestive, } \\
\text { respiratory and } \\
\text { musculoskeletal in } \\
\text { that order. } 24 \% \text { had } \\
4 \text { or more } \\
\text { depression/PTSD } \\
\text { symptoms. }\end{array}$ \\
\hline
\end{tabular}


medRxiv preprint doi: https://doi.org/10.1101/2020.10.15.20213025; this version posted October 20, 2020. The copyright holder for this preprint (which was not certified by peer review) is the author/funder, who has granted medRxiv a license to display the preprint in perpetuity. All rights reserved. No reuse allowed without permission.

\begin{tabular}{|c|c|c|c|c|c|c|c|}
\hline $\begin{array}{l}\text { Wright } \\
(2010)(56)\end{array}$ & Kuwait & EMRO & $\begin{array}{c}\text { Cross } \\
\text { sectional }\end{array}$ & $\begin{array}{c}\text { Patients in } \\
\text { Kuwait } \\
\text { following the } \\
\text { Iraqi invasion }\end{array}$ & $\begin{array}{c}\text { December } \\
2003- \\
\text { January } \\
2005\end{array}$ & $\begin{array}{c}5028 \\
\text { subjects }\end{array}$ & $\begin{array}{l}\text { Study suggested that } \\
\text { those who reported } \\
\text { highest stress } \\
\text { exposure in the } \\
\text { invasion were more } \\
\text { than twice as likely } \\
\text { to report asthma. } \\
\text { Suggestive of } \\
\text { correlation between } \\
\text { war trauma and } \\
\text { asthma. }\end{array}$ \\
\hline
\end{tabular}

Table 4: Characteristics of included publications: Diabetes Mellitus

\begin{tabular}{|c|c|c|c|c|c|c|c|}
\hline & $\begin{array}{c}\text { Country/ } \\
\text { Territory } \\
\text { of Interest }\end{array}$ & $\begin{array}{l}\text { WHO } \\
\text { region }\end{array}$ & Type of study & $\begin{array}{c}\text { Target } \\
\text { Population }\end{array}$ & $\begin{array}{c}\text { Years of } \\
\text { observation }\end{array}$ & $\begin{array}{l}\text { Number of } \\
\text { study } \\
\text { participants }\end{array}$ & Major findings \\
\hline $\begin{array}{l}\text { Abukhdeir } \\
(2013)(32)\end{array}$ & $\begin{array}{l}\text { Palestinian } \\
\text { Territories: } \\
\text { West } \\
\text { Bank/Gaza }\end{array}$ & EMRO & Cross sectional & $\begin{array}{c}\text { Palestinian } \\
\text { households in the } \\
\text { West Bank and } \\
\text { Gaza Strip }\end{array}$ & $\begin{array}{l}\text { May } 2004 \text { - } \\
\text { July } 2004\end{array}$ & $\begin{array}{l}4456 \\
\text { households } \\
\text { in the West } \\
\text { Bank and } \\
2118 \text { in the } \\
\text { Gaza Strip }\end{array}$ & $\begin{array}{l}\text { Being a refugee was a significant } \\
\text { risk factor for diabetes and CVD } \\
\text { while being married/engaged or } \\
\text { divorced/separated/ widowed was } \\
\text { a risk factor for diabetes and } \\
\text { hypertension. Non-refugees were } \\
33 \% \text { less likely to have diabetes } \\
\text { and } 46 \% \text { less likely to have CVD } \\
\text { than refugees. Gender was a risk } \\
\text { factor for hypertension with } \\
\text { females being } 60 \% \text { more likely to } \\
\text { have hypertension than males. }\end{array}$ \\
\hline Ahmad (2015)(85) & Syria & EMRO & $\begin{array}{l}\text { Situational } \\
\text { analysis using } \\
\text { document } \\
\text { analysis, key } \\
\text { informant } \\
\text { interviews, and } \\
\text { direct clinic } \\
\text { observation }\end{array}$ & $\begin{array}{l}\text { Syrian national } \\
\text { health system }\end{array}$ & $\begin{array}{l}\text { October } \\
2009- \\
\text { August } \\
2010\end{array}$ & $\begin{array}{l}53 \text { semi- } \\
\text { structured } \\
\text { interviews }\end{array}$ & $\begin{array}{l}\text { The rebuilding of a post-conflict } \\
\text { heath care system in Syria may } \\
\text { benefit from insights into the } \\
\text { structural problems of the pre- } \\
\text { crisis system. Weaknesses that } \\
\text { existed before the crisis are } \\
\text { compounded by the current } \\
\text { conflict. The authors suggest an } \\
\text { over reliance on secondary and } \\
\text { tertiary care for DM patients with } \\
\text { withdrawal of the Syrian } \\
\text { government from the public health } \\
\text { clinics, which led to escalating } \\
\text { healthcare costs and fostered } \\
\text { increasingly unequal access. }\end{array}$ \\
\hline Alabed (2014)(105) & $\begin{array}{l}\text { Country of } \\
\text { Asylum: } \\
\text { Syria } \\
\text { Country of } \\
\text { Origin: } \\
\text { Palestinian } \\
\text { Territories }\end{array}$ & EMRO & Cross sectional & $\begin{array}{c}\text { Palestinian } \\
\text { refugees living in } \\
\text { Damascus } \\
\text { attending three } \\
\text { UNRWA health } \\
\text { clinics }\end{array}$ & $\begin{array}{l}\text { August } \\
2008 \text { - } \\
\text { September } \\
2008\end{array}$ & $\begin{array}{l}154 \mathrm{DM} \\
\text { patients }\end{array}$ & $\begin{array}{l}\text { UNRWA clinic inspections } \\
\text { highlighted shortages in drug } \\
\text { stocks with } 47.3 \% \text { of patients } \\
\text { reporting problems accessing } \\
\text { prescribed medications and } 67.7 \% \\
\text { reporting having to buy } \\
\text { medications at their own expense } \\
\text { at least once since their diagnosis. } \\
\text { Patients' knowledge of their } \\
\text { condition was limited, Patients } \\
\text { were generally unaware of the } \\
\text { importance of good glucose } \\
\text { control and disease management. } \\
\text { Women were more likely to attend } \\
\text { the clinic than men, with } 71 \% \text { of } \\
\text { patients being female. }\end{array}$ \\
\hline $\begin{array}{l}\text { Ali-Shtayeh } \\
(2012)(82)\end{array}$ & $\begin{array}{l}\text { Palestinian } \\
\text { Territories: } \\
\text { West Bank }\end{array}$ & EMRO & Cross sectional & $\begin{array}{l}\text { Patients } \\
\text { attending } \\
\text { outpatient }\end{array}$ & $\begin{array}{l}\text { August } \\
2010 \text { - May } \\
2011 \\
\end{array}$ & $\begin{array}{c}1,883 \mathrm{DM} \\
\text { patients }\end{array}$ & $\begin{array}{c}\text { While all patients using } \\
\text { complementary and alternative } \\
\text { medicine (CAM) were additionally }\end{array}$ \\
\hline
\end{tabular}


medRxiv preprint doi: https://doi.org/10.1101/2020.10.15.20213025; this version posted October 20, 2020. The copyright holder for this preprint (which was not certified by peer review) is the author/funder, who has granted medRxiv a license to display the preprint in perpetuity. All rights reserved. No reuse allowed without permission.

\begin{tabular}{|c|c|c|c|c|c|c|c|}
\hline & $\begin{array}{c}\text { Country/ } \\
\text { Territory } \\
\text { of Interest }\end{array}$ & $\begin{array}{l}\text { WHO } \\
\text { region }\end{array}$ & Type of study & $\begin{array}{c}\text { Target } \\
\text { Population }\end{array}$ & $\begin{array}{c}\text { Years of } \\
\text { observation }\end{array}$ & $\begin{array}{l}\text { Number of } \\
\text { study } \\
\text { participants }\end{array}$ & Major findings \\
\hline & & & & $\begin{array}{l}\text { departments at } \\
\text { West Bank } \\
\text { Governmental } \\
\text { Hospitals in } 7 \\
\text { towns in the } \\
\text { Palestinian } \\
\text { territories (Jenin, } \\
\text { Nablus, } \\
\text { Tulkarm, } \\
\text { Qalqilia, Tubas, } \\
\text { Ramalla, and } \\
\text { Hebron) }\end{array}$ & & & $\begin{array}{l}\text { using conventional therapies, the } \\
\text { use of CAM differed significantly } \\
\text { between residents of refugee } \\
\text { camps versus residents of urban or } \\
\text { rural areas }(\mathrm{p}=0.034) \text {. More } \\
\text { residents in a refugee camp } \\
\text { reported using CAM vs. not using } \\
\text { CAM as compared to those who } \\
\text { reported living in a village or city. } \\
\text { Most CAM users were above } 40 \\
\text { years old, predominantly female, } \\
\text { and residents of refugee camps and } \\
\text { rural areas. }\end{array}$ \\
\hline AlKasseh (2013)(84) & $\begin{array}{l}\text { Palestinian } \\
\text { Territories: } \\
\text { Gaza }\end{array}$ & EMRO & $\begin{array}{l}\text { Retrospective } \\
\text { case control }\end{array}$ & $\begin{array}{l}\text { Refugee women } \\
\text { attending the } \\
\text { UNRWA } \\
\text { postnatal clinics } \\
\text { in Gaza }\end{array}$ & $\begin{array}{l}\text { March } \\
\text { 2011 - June } \\
2011\end{array}$ & $\begin{array}{l}189 \text { postnatal } \\
\text { GDM } \\
\text { women with } \\
189 \text { matched } \\
\text { controls by } \\
\text { age and } \\
\text { place of } \\
\text { residency }\end{array}$ & $\begin{array}{l}\text { A history of miscarriage more than } \\
\text { once, being overweight before } \\
\text { pregnancy, history of stillbirth, } \\
\text { history of caesarean birth and } \\
\text { positive family history of diabetes } \\
\text { mellitus were strongly correlated } \\
\text { with developing gestational } \\
\text { diabetes(GDM). WHO criteria for } \\
\text { screening for GDM remain a good } \\
\text { instrument to identify GDM in } \\
\text { refugee populations in war-torn } \\
\text { countries (like the Gaza Strip). }\end{array}$ \\
\hline An $(2014)(68)$ & China & $\begin{array}{l}\text { Western } \\
\text { Pacific }\end{array}$ & $\begin{array}{l}\text { Retrospective } \\
\text { cohort }\end{array}$ & $\begin{array}{l}1976 \text { Tangshan } \\
\text { Earthquake } \\
\text { survivors, aged } \\
\text { 37-60, without } \\
\text { severe liver } \\
\text { disease, trauma } \\
\text { surgery, } \\
\text { secondary } \\
\text { diabetes, or } \\
\text { diagnosed } \\
\text { mental disease } \\
\end{array}$ & $\begin{array}{l}\text { September } \\
2013 \text { - } \\
\text { December } \\
2013\end{array}$ & $\begin{array}{c}1030 \\
\text { exposed } \\
\text { subjects }\end{array}$ & $\begin{array}{l}\text { The incidences of impaired fasting } \\
\text { glucose and DM for earthquake } \\
\text { survivors were significantly higher } \\
\text { than that for the control group. } \\
\text { There was a higher diabetes } \\
\text { incidence in those who had lost } \\
\text { relatives than those who had not } \\
\text { lost relatives, however, this effect } \\
\text { was only statistically significant in } \\
\text { women earthquake survivors. }\end{array}$ \\
\hline Armenian (1998)(34) & Armenia & Europe & $\begin{array}{l}\text { Retrospective } \\
\text { cohort }\end{array}$ & $\begin{array}{l}\text { Employees of the } \\
\text { Armenian } \\
\text { Ministry of } \\
\text { Health and their } \\
\text { immediate } \\
\text { families who } \\
\text { survived the } \\
\text { 1988 Earthquake } \\
\text { in Armenia }\end{array}$ & 1990-1992 & $\begin{array}{c}35,043 \\
\text { persons } \\
(7,721 \\
\text { employees } \\
\text { who had } \\
\text { survived the } \\
\text { disaster and } \\
\text { their family } \\
\text { members) }\end{array}$ & $\begin{array}{l}\text { Longer term increased rates of DM } \\
\text { morbidity following an earthquake } \\
\text { are related in a dose-response type } \\
\text { relationship to the intensity of } \\
\text { exposure to disaster. Bereavement, } \\
\text { injuries in the family, and material } \\
\text { loss, act as independent predictors } \\
\text { of long term adverse physical } \\
\text { illness including for DM. }\end{array}$ \\
\hline $\begin{array}{l}\text { Balabanova } \\
(2009)(77)\end{array}$ & Georgia & Europe & $\begin{array}{l}\text { Rapid appraisal } \\
\text { process with } \\
\text { snowball } \\
\text { sampling }\end{array}$ & $\begin{array}{l}\text { Georgian health } \\
\text { system } \\
\text { evaluation }\end{array}$ & $\begin{array}{l}\text { March - } \\
\text { April } 2006\end{array}$ & $\begin{array}{c}36 \\
\text { interviews }\end{array}$ & $\begin{array}{l}\text { Essential inputs for diabetes care } \\
\text { are in place (free insulin, training } \\
\text { for primary care physicians, } \\
\text { financed package of care), but } \\
\text { constraints within the system } \\
\text { hamper the delivery of accessible } \\
\text { and affordable care. The scope of } \\
\text { work of primary care practitioners } \\
\text { is limited and they rarely diagnose } \\
\text { and manage diabetes, which } \\
\text { instead takes place in the context } \\
\text { of a hospital admission and } \\
\text { tertiary-level endocrinologists. } \\
\text { Obtaining syringes, supplies and } \\
\text { hypoglycemic drugs and self- } \\
\text { monitoring equipment remains } \\
\text { difficult and leads to a cost driven } \\
\text { shift toward insulin for diabetic } \\
\text { management. }\end{array}$ \\
\hline $\begin{array}{c}\text { Ben } \\
\text { Romdhane(2015)(86) }\end{array}$ & Tunisia & EMRO & $\begin{array}{c}\text { Situational } \\
\text { analysis }\end{array}$ & $\begin{array}{c}\text { Tunisian national } \\
\text { health system }\end{array}$ & 2010 & $\begin{array}{l}12 \text { key } \\
\text { informants } \\
\text { were }\end{array}$ & $\begin{array}{c}\text { Weaknesses that existed before the } \\
2011 \text { Revolution(Arab Spring) } \\
\text { were compounded during the }\end{array}$ \\
\hline
\end{tabular}


medRxiv preprint doi: https://doi.org/10.1101/2020.10.15.20213025; this version posted October 20, 2020. The copyright holder for this preprint (which was not certified by peer review) is the author/funder, who has granted medRxiv a license to display the preprint in perpetuity. All rights reserved. No reuse allowed without permission.

\begin{tabular}{|c|c|c|c|c|c|c|c|}
\hline & $\begin{array}{c}\text { Country/ } \\
\text { Territory } \\
\text { of Interest }\end{array}$ & $\begin{array}{l}\text { WHO } \\
\text { region }\end{array}$ & Type of study & $\begin{array}{c}\text { Target } \\
\text { Population }\end{array}$ & $\begin{array}{c}\text { Years of } \\
\text { observation }\end{array}$ & $\begin{array}{l}\text { Number of } \\
\text { study } \\
\text { participants }\end{array}$ & Major findings \\
\hline & & & & & & $\begin{array}{l}\text { interviewed } \\
\text { and eight } \\
\text { documents } \\
\text { were } \\
\text { reviewed }\end{array}$ & $\begin{array}{l}\text { revolution. This study was } \\
\text { conducted prior to political } \\
\text { conflict but written post-conflict. } \\
\text { Growth of the private sector } \\
\text { fostered unequal access by } \\
\text { socioeconomic status and reduced } \\
\text { coordination and preparedness of } \\
\text { the health system. }\end{array}$ \\
\hline Besancon (2015)(44) & Mali & Africa & Case study & $\begin{array}{c}\text { Mali diabetic } \\
\text { population } \\
\text { following a } \\
\text { March } 2012 \\
\text { Coup in Bamako }\end{array}$ & $\begin{array}{l}\text { Spring } 2012 \\
\text { following } \\
\text { the March } \\
2012 \text { coup }\end{array}$ & -- & $\begin{array}{l}\text { Diabetics are a vulnerable } \\
\text { population in humanitarian crisis } \\
\text { due to their continuous need for } \\
\text { health care and medicines and the } \\
\text { financial burden this may place on } \\
\text { them. The authors propose that in } \\
\text { an emergency setting there is not } \\
\text { one single diabetes population that } \\
\text { should be considered in planning } \\
\text { humanitarian responses, but } \\
\text { multiple, each with unique needs. } \\
\text { These sub-populations include } \\
\text { people still in active conflict } \\
\text { regions, IDPs, refugees, and the } \\
\text { population which houses IDPs. }\end{array}$ \\
\hline Ebling (2007)(47) & Croatia & Europe & $\begin{array}{l}\text { Multipart study } \\
\text { including both } \\
\text { a retrospective } \\
\text { cohort study } \\
\text { and an } \\
\text { uncontrolled } \\
\text { before-after } \\
\text { study }\end{array}$ & $\begin{array}{l}\text { Refugee- } \\
\text { returnees of the } \\
\text { 1991-1992 war } \\
\text { operations in } \\
\text { Eastern Slavonia } \\
\text { from Osjek- } \\
\text { Baranga County, } \\
\quad \text { Croatia }\end{array}$ & 2003 & $\begin{array}{l}\text { retrospective } \\
\text { cohort study: } \\
589 \\
\text { participants } \\
\\
\text { uncontrolled } \\
\text { before-after } \\
\text { study } 202 \\
\text { participants }\end{array}$ & $\begin{array}{l}\text { The participation of subjects with } \\
\text { DM in the population of refugee- } \\
\text { returnees despite similar } \\
\text { demographic indicators, exceeded } \\
\text { values for both Slavonia and } \\
\text { Croatia. Extremely high } \\
\text { participation of patients with } \\
\text { diabetes was noted(10.5\%), } \\
\text { despite a lower proportion of aged } \\
\text { people over } 65 \text { among returnees. }\end{array}$ \\
\hline Eljedi (2006)(71) & $\begin{array}{c}\text { Palestinian } \\
\text { Territories: } \\
\text { Gaza }\end{array}$ & EMRO & Cross sectional & $\begin{array}{l}\text { Patients with } \\
\text { DM residing in } \\
\text { refugee camps in } \\
\text { Gaza Strip }\end{array}$ & $\begin{array}{l}\text { November } \\
2003 \text { - } \\
\text { December } \\
2004\end{array}$ & $\begin{array}{l}197 \mathrm{DM} \\
\text { patients }\end{array}$ & $\begin{array}{l}\text { Using the World Health } \\
\text { Organization Quality of Life } \\
\text { questionnaire (WHOQOL-BREF) } \\
\text { four domains--including physical } \\
\text { health, psychological, social } \\
\text { relations, and environment -- were } \\
\text { strongly reduced in diabetic } \\
\text { patients as compared to controls, } \\
\text { with stronger effects in physical } \\
\text { health ( } 36.7 \text { vs. } 75.9 \text { points of the } \\
0-100 \text { score) and psychological } \\
\text { domains ( } 34.8 \text { vs. } 70.0 \text { ) and } \\
\text { weaker effects in social } \\
\text { relationships ( } 52.4 \text { vs. } 71.4 \text { ) and } \\
\text { environment domains ( } 23.4 \text { vs. } \\
\text { 36.2). The impact of diabetes on } \\
\text { health-related quality of life } \\
\text { (HRQOL). was especially severe } \\
\text { among females and older subjects } \\
\text { (above } 50 \text { years). }\end{array}$ \\
\hline Gilder (2014)(93) & $\begin{array}{l}\text { Country of } \\
\text { Asylum: } \\
\text { Thailand } \\
\text { Country of } \\
\text { Origin: } \\
\text { Myanmar }\end{array}$ & $\begin{array}{l}\text { South- } \\
\text { East } \\
\text { Asia }\end{array}$ & Cross sectional & $\begin{array}{l}\text { Women } \\
\text { attending the } \\
\text { antenatal care } \\
\text { (ANC) clinic in } \\
\text { Maela refugee } \\
\text { camp on the } \\
\text { Thai-Myanmar } \\
\text { border }\end{array}$ & $\begin{array}{l}\text { July } 2011 \text { - } \\
\text { March } 2012\end{array}$ & 228 women & $\begin{array}{l}\text { The prevalence of GDM is lower } \\
\text { in this population compared with } \\
\text { other populations, but still } \\
\text { complicates } 10 \% \text { of pregnancies. } \\
\text { Despite the weight of evidence for } \\
\text { the benefits of early diagnosis and } \\
\text { treatment of GDM, the absence of } \\
\text { a simple, inexpensive and } \\
\text { applicable screening method } \\
\text { remains a major barrier to GDM } \\
\text { screening programs in refugee } \\
\text { camps and other resource-poor } \\
\text { settings. }\end{array}$ \\
\hline Habtu (1999)(75) & Ethiopia & Africa & Cross Sectional & Insulin treated & Six month & 100 patients & The correct prescribed dose of \\
\hline
\end{tabular}


medRxiv preprint doi: https://doi.org/10.1101/2020.10.15.20213025; this version posted October 20, 2020. The copyright holder for this preprint (which was not certified by peer review) is the author/funder, who has granted medRxiv a license to display the preprint in perpetuity. All rights reserved. No reuse allowed without permission.

\begin{tabular}{|c|c|c|c|c|c|c|c|}
\hline & $\begin{array}{c}\text { Country/ } \\
\text { Territory } \\
\text { of Interest }\end{array}$ & $\begin{array}{l}\text { WHO } \\
\text { region }\end{array}$ & Type of study & $\begin{array}{c}\text { Target } \\
\text { Population }\end{array}$ & $\begin{array}{c}\text { Years of } \\
\text { observation }\end{array}$ & $\begin{array}{l}\text { Number of } \\
\text { study } \\
\text { participants }\end{array}$ & Major findings \\
\hline & & & & $\begin{array}{l}\text { diabetic patients } \\
\text { from the } \\
\text { Diabetic Clinic } \\
\text { at the Mekelle } \\
\text { Hospital in rural } \\
\text { Tigray, Northern } \\
\text { Ethiopia- the } \\
\text { center of the } \\
\text { severe Ethiopian } \\
\text { famine of the } \\
\text { mid-1980s }\end{array}$ & $\begin{array}{c}\text { period in } \\
1997\end{array}$ & & $\begin{array}{l}\text { insulin was only being taken by } \\
50 \% \text { of patients and the correct } \\
\text { syringe by only } 12 \% \text {. Insulin } \\
\text { treatment had been interrupted in } \\
48 \% \text { of cases due to lack of } \\
\text { supply. Low BMI(mean of } 15.8 \text { ), } \\
\text { young age, and resistance to } \\
\text { diabetic ketoacidosis(DKA) } \\
\text { amongst study participants were } \\
\text { consistent with previous } \\
\text { descriptions of malnutrition } \\
\text { related diabetes mellitus(MRDM). }\end{array}$ \\
\hline Hult (2010)(40) & Nigeria & Africa & $\begin{array}{l}\text { Retrospective } \\
\text { Cohort }\end{array}$ & $\begin{array}{c}40 \text { year old } \\
\text { Nigerians with } \\
\text { fetal exposure to } \\
\text { famine in Biafra, } \\
\text { Nigeria during } \\
\text { the Nigerian civil } \\
\text { war (1967-1970) } \\
\end{array}$ & $\begin{array}{c}\text { June } 2009- \\
\text { July } 2009\end{array}$ & $\begin{array}{l}1,339 \text { study } \\
\text { participants }\end{array}$ & $\begin{array}{l}\text { Fetal and infant undernutrition was } \\
\text { associated with significantly } \\
\text { increased risk of impaired glucose } \\
\text { tolerance in } 40 \text { year old Nigerians. } \\
\text { However, early childhood } \\
\text { exposure was not associated with } \\
\text { increased risk. }\end{array}$ \\
\hline Kallab (2015)(19) & $\begin{array}{l}\text { Country of } \\
\text { Asylum: } \\
\text { Lebanon } \\
\text { Country of } \\
\text { Origin: } \\
\text { Syria }\end{array}$ & EMRO & $\begin{array}{l}\text { Program } \\
\text { implementation } \\
\text { reflection }\end{array}$ & $\begin{array}{l}\text { Syrian refugees } \\
\text { and vulnerable } \\
\text { Lebanese host } \\
\text { communities } \\
\text { over the age of } \\
\quad 40\end{array}$ & $\begin{array}{l}\text { November } \\
\text { 2014- May } \\
2015\end{array}$ & 1825 patients & $\begin{array}{l}\text { DM accounted for } 54 \% \text { of patient } \\
\text { cases, with } 27 \% \text { of patients } \\
\text { affected by both DM and HTN. } \\
\text { Principal barriers to providing } \\
\text { diabetic management in active } \\
\text { conflict included insecurity, the } \\
\text { fluid movement of refugees, } \\
\text { limited opening hours of the } \\
\text { centers, transportation costs, and } \\
\text { medication shortages. }\end{array}$ \\
\hline Karrouri (2014)(69) & $\begin{array}{l}\text { Country of } \\
\text { Asylum: } \\
\text { Tunisia } \\
\text { Country of } \\
\text { Origin: } \\
\text { Libya }\end{array}$ & EMRO & Case report & $\begin{array}{l}\text { Case of a 10- } \\
\text { year-old Libyan } \\
\text { boy }\end{array}$ & -- & One patient & $\begin{array}{l}\text { Report of a } 10 \text { year old without } \\
\text { personal or familial diabetes } \\
\text { mellitus history who developed } \\
\text { type } 1 \text { diabetes appeared } \\
\text { immediately following severe } \\
\text { psychological trauma. }\end{array}$ \\
\hline Khader (2012)(81) & $\begin{array}{l}\text { Country of } \\
\text { Asylum: } \\
\text { Jordan } \\
\text { Country of } \\
\text { Origin: } \\
\text { Palestinian } \\
\text { Territories }\end{array}$ & EMRO & $\begin{array}{l}\text { Retrospective } \\
\text { cohort }\end{array}$ & $\begin{array}{l}\text { Persons with } \\
\text { DM at Nuzha } \\
\text { PHC Clinic }\end{array}$ & $\begin{array}{c}\text { October } \\
\text { 2009- } \\
\text { March 2012 }\end{array}$ & $\begin{array}{c}2,851 \\
\text { patients }\end{array}$ & $\begin{array}{l}\text { A directly observed } \\
\text { therapy(DOTS) cohort monitoring } \\
\text { system can be successfully } \\
\text { adapted and used to monitor and } \\
\text { report on Palestinian refugees with } \\
\text { DM in Jordan. A sizeable } \\
\text { proportion of DM patients of the } \\
\text { clinic failed to have postprandial } \\
\text { blood glucose measurements, and } \\
\text { BP measurements in those with } \\
\text { comorbid HTN. }\end{array}$ \\
\hline $\begin{array}{l}\text { Khader } \\
(2013)(78)\end{array}$ & $\begin{array}{l}\text { Country of } \\
\text { Asylum: } \\
\text { Jordan } \\
\text { Country of } \\
\text { Origin: } \\
\text { Palestinian } \\
\text { Territories }\end{array}$ & EMRO & $\begin{array}{l}\text { Retrospective } \\
\text { cohort }\end{array}$ & $\begin{array}{l}\text { Palestine } \\
\text { refugees living in } \\
\text { Jordan }\end{array}$ & $\begin{array}{l}\text { October } \\
\text { 2009- June } \\
2013\end{array}$ & $\begin{array}{c}12,549 \text { total } \\
\text { patients }\end{array}$ & $\begin{array}{l}\text { High burden of disease due to DM } \\
\text { amongst Palestinian refugees at } \\
\text { UNRWA primary health care } \\
\text { clinics in Jordan. Cohort analysis } \\
\text { using e-Health is a successful tool } \\
\text { for to assess management and } \\
\text { follow-up of DM patients. } \\
\text { Complications, including } \\
\text { myocardial infarction and end- } \\
\text { stage renal disease were } \\
\text { significantly more common in } \\
\text { males. Females were more likely } \\
\text { to be obese. }\end{array}$ \\
\hline $\begin{array}{l}\text { Khader } \\
(2014)(79)\end{array}$ & $\begin{array}{l}\text { Country of } \\
\text { Asylum: } \\
\text { Jordan } \\
\text { Country of }\end{array}$ & EMRO & $\begin{array}{l}\text { Retrospective } \\
\text { cohort }\end{array}$ & $\begin{array}{c}\text { Palestinian } \\
\text { refugees living in } \\
\text { Jordan with DM } \\
\text { attending } \\
\text { Nunzha Clinic } \\
\end{array}$ & 2012 & $\begin{array}{l}2,974 \mathrm{DM} \\
\text { patients }\end{array}$ & $\begin{array}{l}\text { E-Health systems are useful for } \\
\text { monitoring patients, since over } \\
\text { half who miss their quarterly } \\
\text { appointment fail to return. } \\
\text { Suggests a need for monitoring }\end{array}$ \\
\hline
\end{tabular}


medRxiv preprint doi: https://doi.org/10.1101/2020.10.15.20213025; this version posted October 20, 2020. The copyright holder for this preprint (which was not certified by peer review) is the author/funder, who has granted medRxiv a license to display the preprint in perpetuity. All rights reserved. No reuse allowed without permission.

\begin{tabular}{|c|c|c|c|c|c|c|c|}
\hline & $\begin{array}{c}\text { Country/ } \\
\text { Territory } \\
\text { of Interest }\end{array}$ & $\begin{array}{l}\text { WHO } \\
\text { region }\end{array}$ & Type of study & $\begin{array}{c}\text { Target } \\
\text { Population }\end{array}$ & $\begin{array}{c}\text { Years of } \\
\text { observation }\end{array}$ & $\begin{array}{l}\text { Number of } \\
\text { study } \\
\text { participants }\end{array}$ & Major findings \\
\hline & $\begin{array}{c}\text { Origin: } \\
\text { Palestinian } \\
\text { Territories }\end{array}$ & & & & & & and active follow-up \\
\hline Khader (2014)(80) & $\begin{array}{l}\text { Country of } \\
\text { Asylum: } \\
\text { Jordan } \\
\text { Country of } \\
\text { Origin: } \\
\text { Palestinian } \\
\text { Territories }\end{array}$ & EMRO & $\begin{array}{l}\text { Retrospective } \\
\text { cohort }\end{array}$ & $\begin{array}{l}\text { Palestinian } \\
\text { refugees living in } \\
\text { Jordan with DM } \\
\text { attending } \\
\text { Nunzha Clinic }\end{array}$ & 2010-2013 & $\begin{array}{l}119 \mathrm{DM} \\
\text { patients }\end{array}$ & $\begin{array}{l}\text { E-health systems are useful for } \\
\text { monitoring patients. An } \\
\text { increasing number of patients had } \\
\text { complications despite no change in } \\
\text { obesity rates indicating places } \\
\text { where more resources may be } \\
\text { useful. }\end{array}$ \\
\hline Li (2010)(73) & China & $\begin{array}{l}\text { Western } \\
\text { Pacific }\end{array}$ & $\begin{array}{l}\text { Retrospective } \\
\text { cohort }\end{array}$ & $\begin{array}{l}\text { Rural Chinese } \\
\text { exposed to the } \\
\text { Chinese } \\
\text { famine(1959- } \\
\text { 1961) during } \\
\text { fetal life and } \\
\text { early childhood }\end{array}$ & 2002 & $\begin{array}{l}\text { 7,874 rural } \\
\text { Chinese }\end{array}$ & $\begin{array}{l}\text { In severely affected famine areas, } \\
\text { fetal-exposed adults had an } \\
\text { increased risk of hyperglycemia } \\
\text { compared with nonexposed } \\
\text { subjects. Differences were not } \\
\text { significant for the early and mid } \\
\text { childhood-exposed cohorts. This } \\
\text { association appears to be } \\
\text { exacerbated by a nutritionally rich } \\
\text { environment in later life. }\end{array}$ \\
\hline Lumey (2015)(74) & Ukraine & Europe & $\begin{array}{l}\text { Retrospective } \\
\text { cohort }\end{array}$ & $\begin{array}{c}\text { Individuals } \\
\text { exposed to the } \\
\text { man-made } \\
\text { Ukrainian } \\
\text { famine of } 1932- \\
33 \text { during } \\
\text { prenatal } \\
\text { development } \\
\text { compared with } \\
\text { all patients with } \\
\text { type } 2 \text { diabetes } \\
\text { diagnosed at age } \\
\text { 40 years or older } \\
\text { in the Ukraine } \\
\text { national diabetes } \\
\text { register } 2000-08\end{array}$ & 2000-2008 & $\begin{array}{l}43,150 \\
\text { patients with } \\
\text { diabetes and } \\
1,421,024 \\
\text { controls }\end{array}$ & $\begin{array}{l}\text { Demonstrates a dose-response } \\
\text { relationship between famine } \\
\text { severity during prenatal } \\
\text { development and odds of type } 2 \\
\text { diabetes in later life. The } \\
\text { associations between type } 2 \\
\text { diabetes and famine around the } \\
\text { time of birth were similar in men } \\
\text { and women. }\end{array}$ \\
\hline Mansour (2008)(76) & Iraq & EMRO & Cross sectional & $\begin{array}{l}\text { Diabetic patients } \\
\text { in an outpatient } \\
\text { clinic in Al- } \\
\text { Faiha general } \\
\text { hospital in } \\
\text { Basrah, South } \\
\text { Iraq }\end{array}$ & $\begin{array}{c}\text { January } \\
2007 \text { - } \\
\text { December } \\
2007\end{array}$ & $\begin{array}{c}3,522 \\
\text { diabetic } \\
\text { patients }\end{array}$ & $\begin{array}{l}\text { The most common reasons for } \\
\text { poor glycemic control(HBA1C } \\
>7 \% \text { ) listed by patients were drug } \\
\text { shortages and drugs and/or } \\
\text { laboratory expense(over } 50 \%) \text {. } \\
30 \% \text { of diabetic patient with poor } \\
\text { glycemic control believed that } \\
\text { their poor glycemic control is due } \\
\text { to migration after the war. }\end{array}$ \\
\hline Mateen $(2012)(30)$ & $\begin{array}{l}\text { Country of } \\
\text { Asylum: } \\
\text { Jordan } \\
\text { Country of } \\
\text { Origin: } \\
\text { Iraq }\end{array}$ & EMRO & Cross sectional & $\begin{array}{l}\text { Iraqi refugees } \\
\text { receiving health } \\
\text { assistance in } \\
\text { Jordan as } \\
\text { recorded by a } \\
\text { UNHCR } \\
\text { database }\end{array}$ & $\begin{array}{c}\text { January } \\
2010- \\
\text { December } \\
2010\end{array}$ & $\begin{array}{l}7642 \text { Iraqi } \\
\text { refugees }\end{array}$ & $\begin{array}{l}11 \% \text { of refugees presented with } \\
\text { type } 2 \text { DM. For all refugees the } \\
\text { largest number of visits were for } \\
\text { essential hypertension (2067 } \\
\text { visits); visual disturbances (1129); } \\
\text { type II diabetes mellitus (1021). }\end{array}$ \\
\hline Mousa (2010)(29) & $\begin{array}{l}\text { Country of } \\
\text { Asylum: } \\
\text { Jordan, } \\
\text { Syria, } \\
\text { Lebanon, } \\
\text { Gaza, West } \\
\text { Bank } \\
\text { Country of } \\
\text { Origin: } \\
\text { Palestinian } \\
\text { Territories }\end{array}$ & EMRO & Cross sectional & $\begin{array}{l}\text { UNRWA } \\
\text { registered } \\
\text { Palestinian } \\
\text { refugees } \\
\text { attending } \\
\text { UNRWA clinics }\end{array}$ & June 2007 & $\begin{array}{c}7,762 \\
\text { refugees }\end{array}$ & $\begin{array}{l}\text { Overall } 9.8 \% \text { of screened refugees } \\
\text { had random blood glucose values } \\
\geq 126 \mathrm{mg} / \mathrm{dL} \text {. Being older than } 40 \\
\text { years, obese or with a positive } \\
\text { family history of diabetes or } \\
\text { cardiovascular disease increased } \\
\text { the risk of presenting with } \\
\text { hyperglycemia } 3.5,1.6 \text { and } 1.2 \\
\text { times respectively. Variations were } \\
\text { statistically significant between } \\
\text { UNRWA locations and between } \\
\text { the sexes. Significant variations } \\
\text { were found between fields for }\end{array}$ \\
\hline
\end{tabular}


medRxiv preprint doi: https://doi.org/10.1101/2020.10.15.20213025; this version posted October 20, 2020. The copyright holder for this preprint (which was not certified by peer review) is the author/funder, who has granted medRxiv a license to display the preprint in perpetuity. All rights reserved. No reuse allowed without permission.

\begin{tabular}{|c|c|c|c|c|c|c|c|}
\hline & $\begin{array}{c}\text { Country/ } \\
\text { Territory } \\
\text { of Interest }\end{array}$ & $\begin{array}{l}\text { WHO } \\
\text { region }\end{array}$ & Type of study & $\begin{array}{c}\text { Target } \\
\text { Population }\end{array}$ & $\begin{array}{c}\text { Years of } \\
\text { observation }\end{array}$ & $\begin{array}{l}\text { Number of } \\
\text { study } \\
\text { participants }\end{array}$ & Major findings \\
\hline & & & & & & & $\begin{array}{c}\text { females }(\chi 2=112.6, \mathrm{P}<0.01) \text { and } \\
\text { for males }(\chi 2=39.2, \mathrm{P}<0.01), \\
\text { with the highest proportion of } \\
\text { cases diagnosed in the Occupied } \\
\text { Palestinian Territories and the } \\
\text { lowest in Jordan and Syria. }\end{array}$ \\
\hline $\begin{array}{l}\text { Ramachandran } \\
(2006)(70)\end{array}$ & India & $\begin{array}{l}\text { South- } \\
\text { East } \\
\text { Asia }\end{array}$ & $\begin{array}{c}\text { Retrospective } \\
\text { cohort }\end{array}$ & $\begin{array}{l}\text { Tsunami affected } \\
\text { population of } \\
\text { Chennai(Madras) } \\
\text { in Southern India }\end{array}$ & $\begin{array}{l}\text { April 2005- } \\
\text { June } 2005\end{array}$ & $\begin{array}{l}1,184 \\
\text { tsunami } \\
\text { affected } \\
\text { subjects, } \\
1,176 \\
\text { controls }\end{array}$ & $\begin{array}{l}\text { Undetected diabetes and impaired } \\
\text { glucose tolerance were higher in } \\
\text { the tsunami-hit area as compared } \\
\text { to controls. Diabetes prevalence } \\
\text { was found to be similar in the } \\
\text { tsunami affected population and } \\
\text { control. Women of both the } \\
\text { control and the tsunami affected } \\
\text { population had both a higher stress } \\
\text { score(using the Harvard trauma } \\
\text { questionnaire) than men with a } \\
\text { significantly higher stress score in } \\
\text { women affected by the tsunami, as } \\
\text { well as a higher prevalence of } \\
\text { impaired glucose tolerance in the } \\
\text { tsunami hit area. }\end{array}$ \\
\hline Read (2015)(46) & $\begin{array}{c}\text { The } \\
\text { Philippines }\end{array}$ & $\begin{array}{l}\text { Western } \\
\text { Pacific }\end{array}$ & Cross sectional & $\begin{array}{c}\text { Patients treated } \\
\text { by an Australian } \\
\text { Government } \\
\text { deployed } \\
\text { surgical team in } \\
\text { a field hospital in } \\
\text { the city of } \\
\text { Tacloban for } 4 \\
\text { weeks after } \\
\text { Typhoon Haiyan }\end{array}$ & $\begin{array}{l}\text { November } \\
2013\end{array}$ & 131 persons & $\begin{array}{l}\text { Sepsis from foot injuries in } \\
\text { diabetic patients constituted an } \\
\text { unexpected majority of the } \\
\text { workload of a foreign } \\
\text { collaborative surgical medical } \\
\text { team in Tacloban in the aftermath } \\
\text { of Typhoon Haiyan. }\end{array}$ \\
\hline Sengul (2004)(72) & Turkey & Europe & $\begin{array}{l}\text { Prospective } \\
\text { cohort }\end{array}$ & $\begin{array}{l}\text { Type } 1 \text { Diabetic } \\
\text { Survivors of the } \\
1999 \text { Marmara } \\
\text { Earthquake }\end{array}$ & $1998-2000$ & 88 subjects & $\begin{array}{c}\text { HbA1c levels and insulin } \\
\text { requirements significantly } \\
\text { increased at the 3rd month post } \\
\text { earthquake however only } \\
\text { increased insulin requirement } \\
\text { continued to be significantly } \\
\text { increased, one year post } \\
\text { earthquake. No significant } \\
\text { difference was identified between } \\
\text { HbA1c levels pre earthquake and } \\
\text { post } 1 \text { year earthquake. Results } \\
\text { indicated that the Marmara } \\
\text { earthquake affected glycemic } \\
\text { control of people with type } 1 \\
\text { diabetes in the short term but its } \\
\text { negative impact did not continue } \\
\text { in long term. }\end{array}$ \\
\hline Sofeh (2004)(83) & $\begin{array}{l}\text { Country of } \\
\text { Asylum: } \\
\text { Pakistan } \\
\text { Country of }\end{array}$ & EMRO & Cross sectional & $\begin{array}{l}\text { Adult Afghan } \\
\text { Refugees } \\
\text { attending Red } \\
\text { Cross health care } \\
\text { facilities in } \\
\end{array}$ & .. & 456 patients & $\begin{array}{l}\text { The frequency of non-insulin } \\
\text { dependent DM was found to be } \\
55.9 \% \text { amongst Afghan refugees } \\
\text { in Peshawar during a two year } \\
\text { study period. } 17.25 \% \text { of diabetics }\end{array}$ \\
\hline
\end{tabular}


medRxiv preprint doi: https://doi.org/10.1101/2020.10.15.20213025; this version posted October 20, 2020. The copyright holder for this preprint (which was not certified by peer review) is the author/funder, who has granted medRxiv a license to display the preprint in perpetuity. All rights reserved. No reuse allowed without permission.

\begin{tabular}{|c|c|c|c|c|c|c|c|}
\hline & $\begin{array}{l}\text { Country/ } \\
\text { Territory } \\
\text { of Interest }\end{array}$ & $\begin{array}{l}\text { WHO } \\
\text { region }\end{array}$ & Type of study & $\begin{array}{c}\text { Target } \\
\text { Population }\end{array}$ & $\begin{array}{c}\text { Years of } \\
\text { observation }\end{array}$ & $\begin{array}{l}\text { Number of } \\
\text { study } \\
\text { participants }\end{array}$ & Major findings \\
\hline & $\begin{array}{c}\text { Origin: } \\
\text { Afghanistan }\end{array}$ & & & $\begin{array}{l}\text { Peshawar, } \\
\text { Pakistan }\end{array}$ & & & $\begin{array}{l}\text { had concomitant hyperlipidemia. } \\
\text { Gender was not identified as a risk } \\
\text { factor for higher fasting blood } \\
\text { glucose levels. }\end{array}$ \\
\hline Strong (2015)(21) & $\begin{array}{l}\text { Country of } \\
\text { Asylum: } \\
\text { Lebanon } \\
\text { Country of } \\
\text { Origin: } \\
\text { Syria }\end{array}$ & EMRO & Cross sectional & $\begin{array}{c}\text { Syrian refugees } \\
\text { over age } 60 \\
\text { residing in } \\
\text { Lebanon and } \\
\text { registered with } \\
\text { either Caritas } \\
\text { Lebanon Migrant } \\
\text { Center (CLMC) } \\
\text { or the } \\
\text { Palestinian } \\
\text { Women's } \\
\text { Humanitarian } \\
\text { Organization } \\
\text { (PALWHO) }\end{array}$ & $\begin{array}{l}\text { March } 2011 \\
\text { - March } \\
2013\end{array}$ & 210 refugees & $\begin{array}{l}47 \% \text { of older refugees had DM. } \\
\text { The number of days older refugees } \\
\text { reporting eating bread only and } \\
\text { nothing else corresponded to their } \\
\text { reported financial status. Financial } \\
\text { difficulties were given as the } \\
\text { primary reason for not seeking } \\
\text { care by } 79 \% \text { of older refugees with } \\
\text { only } 1.5 \% \text { stating they had no } \\
\text { difficulties in obtaining care when } \\
\text { needed. }\end{array}$ \\
\hline Wagner (2016)(123) & Cambodia & $\begin{array}{l}\text { Western } \\
\text { Pacific }\end{array}$ & $\begin{array}{l}\text { Uncontrolled } \\
\text { before and after }\end{array}$ & $\begin{array}{c}\text { Unpaid } \\
\text { Cambodian } \\
\text { village health } \\
\text { guide volunteers } \\
\text { were trained in } \\
\text { DM prevention } \\
\text { teaching } \\
\text { behaviors }\end{array}$ & .. & $\begin{array}{l}185 \text { guides } \\
\text { were trained } \\
\text { to instruct at } \\
10 \text { health } \\
\text { centers }\end{array}$ & $\begin{array}{l}\text { Knowledge of community health } \\
\text { workers on DM prevention } \\
\text { techniques increased significantly } \\
\text { from pre-test to posttest after } 6 \\
\text { months of follow-up. } 159 \text { guides } \\
\text { (85\%) completed at least one } \\
\text { monthly checklist. }\end{array}$ \\
\hline Yaghi (2012)(94) & Lebanon & EMRO & Cross sectional & $\begin{array}{l}\text { Cases of } \\
\text { amputations in } \\
\text { Lebanon }\end{array}$ & $\begin{array}{l}\text { January } \\
\text { 2007- } \\
\text { December } \\
2007\end{array}$ & $\begin{array}{c}661 \\
\text { amputations }\end{array}$ & $\begin{array}{c}\text { Diabetes and vascular indications } \\
\text { were } \\
\text { not only more common than } \\
\text { trauma-related amputation, but } \\
\text { both were associated with more } \\
\text { major surgery and longer } \\
\text { hospital stay including conflict } \\
\text { afflicted southern } \\
\text { Lebanon where trauma, diabetes } \\
\text { and vascular disease amputations } \\
\text { all occurred at more than twice the } \\
\text { national rate. }\end{array}$ \\
\hline Yusef (2000)(22) & $\begin{array}{l}\text { Country of } \\
\text { Asylum: } \\
\text { Lebanon } \\
\text { Country of } \\
\text { Origin: } \\
\text { Palestinian } \\
\text { Territories }\end{array}$ & EMRO & Cross sectional & $\begin{array}{l}\text { Diabetic and } \\
\text { hypertensive } \\
\text { patients } \\
\text { attending } \\
\text { UNRWA } \\
\text { primary health } \\
\text { care facilities in } \\
\text { Lebanon }\end{array}$ & 1997 & $\begin{array}{c}2,202 \\
\text { records }\end{array}$ & $\begin{array}{l}\text { Presence of both DM and HTN } \\
\text { increased the risk for late-stage } \\
\text { complications. Only } 18.2 \% \text { of } \\
\text { diabetic patients and only } 17.7 \% \\
\text { of DM patients with HTN were } \\
\text { managed by lifestyle modification. } \\
\text { About } 50 \% \text { of type } 2 \text { and } 66 \% \text { of } \\
\text { type } 1 \text { patients who were on } \\
\text { insulin were well controlled. }\end{array}$ \\
\hline
\end{tabular}

Table 5: Characteristics of included publications by disease type: Other Non-Communicable Diseases

\begin{tabular}{|l|c|c|c|c|c|c|c|}
\hline & $\begin{array}{c}\text { Country/Territory } \\
\text { of Interest }\end{array}$ & $\begin{array}{c}\text { WHO } \\
\text { region }\end{array}$ & Type of study & $\begin{array}{c}\text { Target } \\
\text { Population }\end{array}$ & $\begin{array}{c}\text { Years of } \\
\text { observation }\end{array}$ & $\begin{array}{c}\text { Number of } \\
\text { study } \\
\text { participants }\end{array}$ & Major findings \\
\hline
\end{tabular}




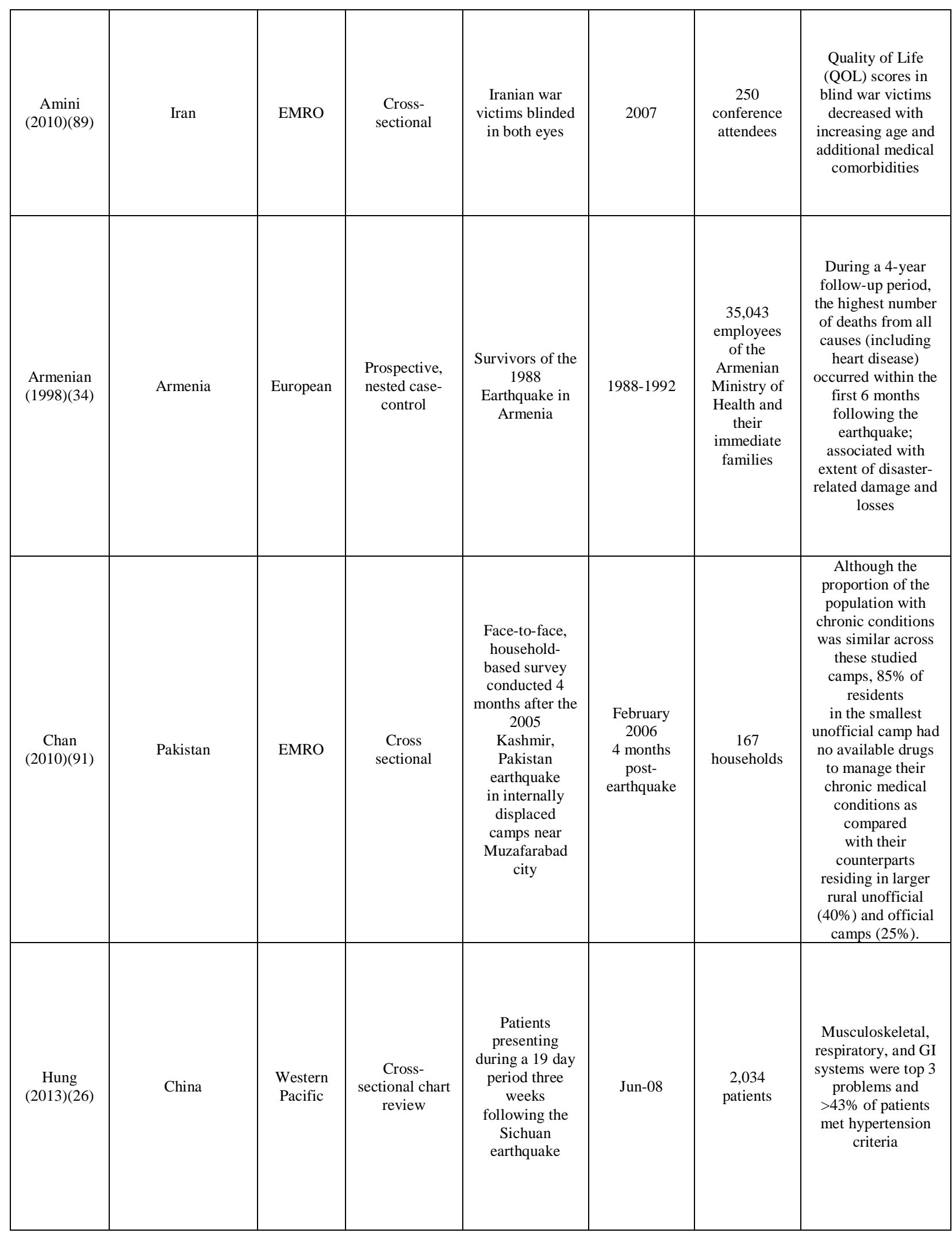




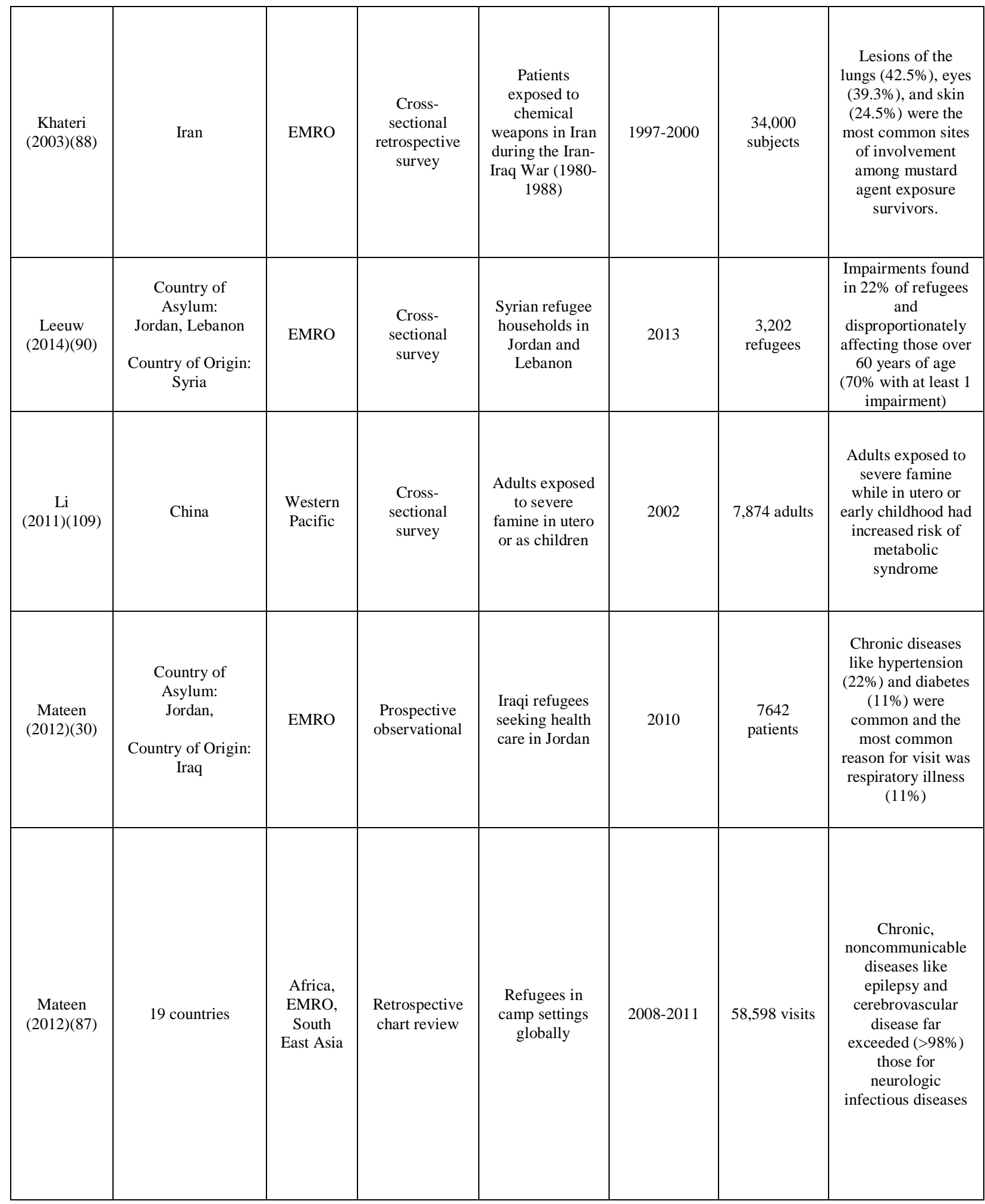


medRxiv preprint doi: https://doi.org/10.1101/2020.10.15.20213025; this version posted October 20, 2020. The copyright holder for this preprint (which was not certified by peer review) is the author/funder, who has granted medRxiv a license to display the preprint in perpetuity.

All rights reserved. No reuse allowed without permission.

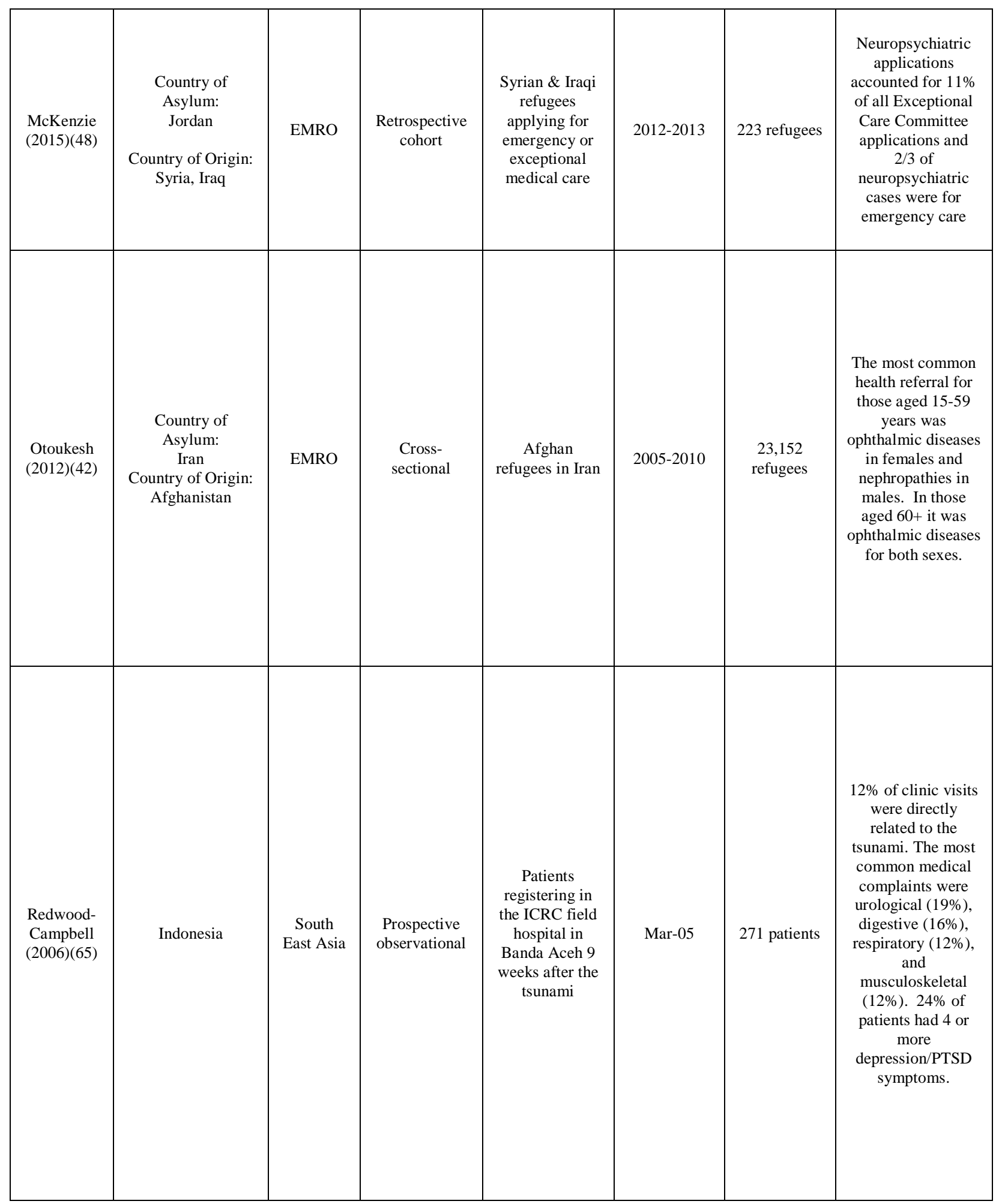


medRxiv preprint doi: https://doi.org/10.1101/2020.10.15.20213025; this version posted October 20, 2020. The copyright holder for this preprint (which was not certified by peer review) is the author/funder, who has granted medRxiv a license to display the preprint in perpetuity.

All rights reserved. No reuse allowed without permission.

\begin{tabular}{|c|c|c|c|c|c|c|c|}
\hline $\begin{array}{c}\text { Sibai } \\
(2001)(20)\end{array}$ & Lebanon & EMRO & $\begin{array}{c}\text { Cross- } \\
\text { sectional }\end{array}$ & $\begin{array}{l}\text { Representative } \\
\text { cohort of men } \\
\text { and women } \\
\text { completing a } \\
\text { health survey in } \\
\text { Beirut, Lebanon } \\
\text { during wartime }\end{array}$ & 1983-1993 & $\begin{array}{c}1567 \\
\text { subjects }\end{array}$ & $\begin{array}{c}\text { Total mortality } \\
\text { rates were } \\
\text { estimated at } 33.7 \\
\text { and } 25.2 / 1000 \\
\text { person years among } \\
\text { men and women } \\
\text { respectively. } \\
\text { Leading cause of } \\
\text { death was } \\
\text { circulatory disease } \\
(60 \%) \text { and cancer } \\
(15 \%) \text { for both } \\
\text { sexes. }\end{array}$ \\
\hline $\begin{array}{c}\text { Strong } \\
(2015)(21)\end{array}$ & $\begin{array}{c}\text { Country of } \\
\text { Asylum: Lebanon } \\
\text { Country of Origin: } \\
\text { Syria, Palestine }\end{array}$ & EMRO & $\begin{array}{c}\text { Cross } \\
\text { Sectional }\end{array}$ & $\begin{array}{l}\text { Refugees over } \\
\text { age } 60 \\
\text { receiving } \\
\text { assistance from } \\
\text { social workers }\end{array}$ & 2011-2013 & 210 refugees & $\begin{array}{c}\text { Most older refugees } \\
\text { reported at least } \\
\text { one non- } \\
\text { communicable } \\
\text { disease: } \\
\text { hypertension } \\
(60 \%), \text { diabetes } \\
(47 \%), \text { heart } \\
\text { disease (30\%). } \\
74 \% \text { indicated at } \\
\text { least some } \\
\text { dependency on } \\
\text { humanitarian } \\
\text { assistance }\end{array}$ \\
\hline
\end{tabular}

Table 6: Characteristics of included publications by region: Africa

\begin{tabular}{|c|c|c|c|c|c|c|c|}
\hline & $\begin{array}{c}\text { Country/Territory } \\
\text { of Interest }\end{array}$ & $\begin{array}{c}\text { Target } \\
\text { Population }\end{array}$ & $\begin{array}{l}\text { Type of } \\
\text { Study }\end{array}$ & $\begin{array}{l}\text { NCD } \\
\text { Studied }\end{array}$ & $\begin{array}{c}\text { Years of } \\
\text { Observation }\end{array}$ & $\begin{array}{l}\text { Number of } \\
\text { study } \\
\text { participants }\end{array}$ & Major Findings \\
\hline $\begin{array}{l}\text { Besancon } \\
(2015)(44)\end{array}$ & Mali & $\begin{array}{c}\text { Mali } \\
\text { diabetic } \\
\text { population } \\
\text { following a } \\
\text { March } 2012 \\
\text { Coup in } \\
\text { Bamako }\end{array}$ & Case Study & Diabetes & $\begin{array}{l}\text { Spring } 2012 \\
\text { following the } \\
\text { March } 2012 \\
\text { coup }\end{array}$ & -- & $\begin{array}{l}\text { Diabetics are a vulnerable } \\
\text { population in humanitarian } \\
\text { crisis due to their } \\
\text { continuous need for health } \\
\text { care and medicines and the } \\
\text { financial burden this may } \\
\text { place on them. In an } \\
\text { emergency setting sub- } \\
\text { populations of diabetics } \\
\text { must be taken into account } \\
\text { for humanitarian response } \\
\text { planning; including people } \\
\text { still in active conflict } \\
\text { regions, IDPs, refugees, and } \\
\text { the host population which } \\
\text { houses IDPs. }\end{array}$ \\
\hline
\end{tabular}




\begin{tabular}{|c|c|c|c|c|c|c|c|}
\hline $\begin{array}{c}\text { Habtu } \\
(1999)(75)\end{array}$ & Ethiopia & $\begin{array}{l}\text { Insulin } \\
\text { treated } \\
\text { diabetic } \\
\text { patients } \\
\text { from the } \\
\text { Diabetic } \\
\text { Clinic at the } \\
\text { Mekelle } \\
\text { Hospital in } \\
\text { rural Tigray, } \\
\text { Northern } \\
\text { Ethiopia- } \\
\text { the center of } \\
\text { the severe } \\
\text { Ethiopian } \\
\text { famine of } \\
\text { the mid- } \\
1980 \text { s } \\
\end{array}$ & $\begin{array}{l}\text { Cross- } \\
\text { sectional }\end{array}$ & Diabetes & $\begin{array}{l}\text { Six month } \\
\text { period in } \\
1997\end{array}$ & 100 patients & $\begin{array}{l}\text { The correct prescribed dose } \\
\text { of insulin was only being } \\
\text { administered in 50\% of DM } \\
\text { patients in rural Tigray, } \\
\text { Ethiopia and the correct } \\
\text { syringe by only } 12 \% \text { of } \\
\text { patients. Insulin treatment } \\
\text { had been interrupted in } 48 \% \\
\text { of cases due to lack of } \\
\text { supply. Low BMI(mean of } \\
\text { 15.8), young age, and } \\
\text { resistance to diabetic } \\
\text { ketoacidosis(DKA) amongst } \\
\text { study participants were } \\
\text { consistent with previous } \\
\text { descriptions of malnutrition } \\
\text { related diabetes } \\
\text { mellitus(MRDM). }\end{array}$ \\
\hline $\begin{array}{c}\text { Huerga } \\
(2009)(95)\end{array}$ & Liberia & $\begin{array}{c}\text { Patients of } \\
\text { the medical } \\
\text { and } \\
\text { pediatric } \\
\text { wards of } \\
\text { Mamba } \\
\text { Point } \\
\text { Hospital, } \\
\text { Monrovia, } \\
\text { Liberia, one } \\
\text { year after } \\
\text { the end of } \\
\text { the Liberian } \\
\text { civil } \\
\text { war }\end{array}$ & $\begin{array}{l}\text { Cross- } \\
\text { sectional }\end{array}$ & $\begin{array}{l}\text { Multiple } \\
\text { NCDs } \\
\text { including } \\
\text { CVD } \\
\text { (stroke, } \\
\text { CHF, and } \\
\text { HTN) }\end{array}$ & $\begin{array}{c}\text { January } 2005 \\
\text { - July } 2005\end{array}$ & $\begin{array}{c}\text { 1,034 adult } \\
\text { patients } \\
1,509 \\
\text { children }\end{array}$ & $\begin{array}{c}\text { Of } 1034 \text { adult hospitalized } \\
\text { patients in post-war Liberia, } \\
529 \text { (51\%) were diagnosed } \\
\text { with a noninfectious } \\
\text { disease. Among the } 241 \\
\text { deaths recorded, the cause } \\
\text { was non-infectious disease } \\
\text { in } 134 \text { (56\%) patients. The } \\
\text { fatality rate for infectious } \\
\text { diseases (19.7\%; } 92 \\
\text { deaths/465 cases) was lower } \\
\text { (P = } 0.04) \text { than for non- } \\
\text { infectious diseases ( } 25.3 \% \text {; } \\
134 \text { deaths/529 cases). } \\
\text { Cardiovascular diseases } \\
\text { caused half of deaths due to } \\
\text { non-infectious diseases: } \\
25 \% \text { stroke, } 18 \% \text { heart } \\
\text { failure and } 10 \% \text { severe } \\
\text { hypertension. No cases of } \\
\text { ischemic heart disease were } \\
\text { identified. } \\
\text {---------------------- } \\
\text { Among hospitalized } \\
\text { children, } \\
229 \text { (15\%) were diagnosed } \\
\text { with a noninfectious } \\
\text { disease. NCDs represented } \\
34 \% \text { of all deaths. The } \\
\text { fatality rate for infectious } \\
\text { diseases ( } 18.6 \% ; 197 \\
\text { deaths/1189 cases) was } \\
\text { lower (P < } 0.01 \text { ) than for } \\
\text { non-infectious diseases } \\
(28.8 \% ; 66 \text { deaths/229 } \\
\text { cases). }\end{array}$ \\
\hline $\begin{array}{c}\text { Hult } \\
(2010)(40)\end{array}$ & Nigeria & $\begin{array}{c}40 \text { year old } \\
\text { Nigerians } \\
\text { with fetal } \\
\text { exposure to } \\
\text { famine in } \\
\text { Biafra, } \\
\text { Nigeria } \\
\text { during the } \\
\text { Nigerian } \\
\text { civil war } \\
(1967-1970)\end{array}$ & $\begin{array}{l}\text { Retrospective } \\
\text { cohort }\end{array}$ & $\begin{array}{l}\text { Diabetes } \\
\text { and HTN }\end{array}$ & $\begin{array}{l}\text { June 2009- } \\
\text { July } 2009\end{array}$ & $\begin{array}{l}1,339 \text { study } \\
\text { participants }\end{array}$ & $\begin{array}{c}\text { Fetal and infant } \\
\text { undernutrition was } \\
\text { associated with significantly } \\
\text { increased risk of } \\
\text { hypertension(adjusted OR } \\
2.87 ; 95 \% \text { CI 1.90-4.34), } \\
\text { and impaired glucose } \\
\text { tolerance (OR 1.65; } 95 \% \text { CI } \\
\text { 1.02-2.69) in } 40 \text { year old } \\
\text { Nigerians. However, early } \\
\text { childhood exposure was not } \\
\text { associated with increased } \\
\text { risk. }\end{array}$ \\
\hline
\end{tabular}


medRxiv preprint doi: https://doi.org/10.1101/2020.10.15.20213025; this version posted October 20, 2020. The copyright holder for this preprint (which was not certified by peer review) is the author/funder, who has granted medRxiv a license to display the preprint in perpetuity. All rights reserved. No reuse allowed without permission.

Table 7: Characteristics of included publications by region: Region of the Americas

\begin{tabular}{|c|c|c|c|c|c|c|c|}
\hline & $\begin{array}{c}\text { Country/Territory } \\
\text { of Interest }\end{array}$ & $\begin{array}{c}\text { Target } \\
\text { Population }\end{array}$ & $\begin{array}{l}\text { Type of } \\
\text { Study }\end{array}$ & $\begin{array}{l}\text { NCD } \\
\text { Studied }\end{array}$ & $\begin{array}{c}\text { Years of } \\
\text { Observation }\end{array}$ & $\begin{array}{l}\text { Number of } \\
\text { study } \\
\text { participants }\end{array}$ & $\begin{array}{l}\text { Major } \\
\text { Findings }\end{array}$ \\
\hline Daniels (2009)(92) & Peru & $\begin{array}{l}\text { Displaced as } \\
\text { well as } \\
\text { nondisplaced } \\
\text { populations } \\
\text { in rural to } \\
\text { urban } \\
\text { settings }\end{array}$ & $\begin{array}{c}\text { Stratified } \\
\text { cluster survey }\end{array}$ & $\begin{array}{l}\text { Multiple } \\
\text { NCDs }\end{array}$ & $\begin{array}{c}2007 \\
\text { (six months } \\
\text { post- } \\
\text { earthquake) }\end{array}$ & $\begin{array}{c}672 \\
\text { households }\end{array}$ & $\begin{array}{c}\text { Displaced } \\
\text { populations } \\
\text { sought care } \\
\text { more, people } \\
\text { with injury or } \\
\text { NCD sought } \\
\text { care more. } \\
\text { People who } \\
\text { did not seek } \\
\text { care cited cost } \\
\text { as a barrier. }\end{array}$ \\
\hline Naumova(2007)(63) & Ecuador & $\begin{array}{l}\text { Pediatric ER } \\
\text { visits with } \\
\text { acute upper } \\
\text { and lower } \\
\text { respiratory } \\
\text { conditions } \\
\text { and asthma } \\
\text { related } \\
\text { conditions }\end{array}$ & $\begin{array}{c}\text { Retrospective } \\
\text { review of } \\
\text { medical } \\
\text { records }\end{array}$ & $\begin{array}{l}\text { Chronic } \\
\text { respiratory } \\
\text { disease } \\
\text { including } \\
\text { asthma }\end{array}$ & $\begin{array}{c}\text { January - } \\
2000 \\
\text { December } \\
2000\end{array}$ & $\begin{array}{c}5,169 \\
\text { emergency } \\
\text { department } \\
\text { records }\end{array}$ & $\begin{array}{c}\text { Rates of ED } \\
\text { visits for } \\
\text { pediatric } \\
\text { patients } \\
\text { increased } \\
\text { significantly } \\
\text { during period } \\
\text { of volcanic } \\
\text { activity. } \\
\text { Youngest } \\
\text { patients (4 and } \\
\text { under) were } \\
\text { most affected. }\end{array}$ \\
\hline
\end{tabular}

Table 8: Characteristics of included publications by region: Eastern Mediterranean Region

\begin{tabular}{|c|c|c|c|c|c|c|c|}
\hline & $\begin{array}{c}\text { Country/ } \\
\text { Territory } \\
\text { of Interest }\end{array}$ & $\begin{array}{c}\text { Target } \\
\text { Population }\end{array}$ & Type of study & NCD studied & $\begin{array}{c}\text { Years of } \\
\text { observatio } \\
\text { n }\end{array}$ & $\begin{array}{c}\text { Number of } \\
\text { study } \\
\text { participant } \\
\text { s }\end{array}$ & Major findings \\
\hline $\begin{array}{l}\text { Abukhdeir } \\
(2013)(32)\end{array}$ & $\begin{array}{c}\text { Palestinian } \\
\text { Territories- } \\
\text { Gaza/ West } \\
\text { Bank }\end{array}$ & $\begin{array}{c}\text { Palestinian } \\
\text { households in } \\
\text { the West } \\
\text { Bank and } \\
\text { Gaza Strip }\end{array}$ & $\begin{array}{l}\text { Cross- } \\
\text { sectional } \\
\text { nationally } \\
\text { representative } \\
\text { household } \\
\text { survey }\end{array}$ & $\begin{array}{c}\text { Diabetes, } \\
\text { hypertension, } \\
\text { cardiovascular } \\
\text { disease }(\mathrm{CVD}) \text { and } \\
\text { cancer }\end{array}$ & 2013 & $\begin{array}{c}4,456 \\
\text { households } \\
\text { in the West } \\
\text { Bank and } \\
2118 \text { in the } \\
\text { Gaza Strip. } \\
\text { The } \\
\text { response } \\
\text { rates for the } \\
2 \text { regions } \\
\text { were } 84.1 \% \\
\text { and } 96.9 \% \\
\text { respectively } \\
.\end{array}$ & $\begin{array}{l}\text { The authors } \\
\text { emphasized that } \\
\text { even though } \\
\text { previous studies } \\
\text { have combined } \\
\text { Palestinians as one } \\
\text { group, they live in } \\
\text { different areas and } \\
\text { are subject to } \\
\text { different health } \\
\text { systems which can } \\
\text { result in different } \\
\text { health outcomes. } \\
\text { Being a refugee was } \\
\text { a significant risk } \\
\text { factor for diabetes } \\
\text { and CVD while } \\
\text { being } \\
\text { married/engaged or } \\
\text { divorced/ separated } \\
\text { widowed was a risk } \\
\text { factor for diabetes } \\
\text { and hypertension. } \\
\text { Non-refugees were } \\
33 \% \text { less likely to } \\
\text { have diabetes and } \\
\text { 46\% less likely to }\end{array}$ \\
\hline
\end{tabular}




\begin{tabular}{|c|c|c|c|c|c|c|c|}
\hline & & & & & & & $\begin{array}{l}\text { have CVD than } \\
\text { refugees. }\end{array}$ \\
\hline $\begin{array}{c}\text { Abul } \\
(2001)(57)\end{array}$ & Kuwait & $\begin{array}{c}\text { Patients } \\
\text { admitted to } \\
\text { hospitals in } \\
\text { Kuwait with } \\
\text { asthma for six } \\
\text { years (1987- } \\
1989 \text { and } \\
\text { 1992-1994) }\end{array}$ & $\begin{array}{c}\text { Retrospective } \\
\text { cross-sectional } \\
\text { study }\end{array}$ & Asthma & 2001 & 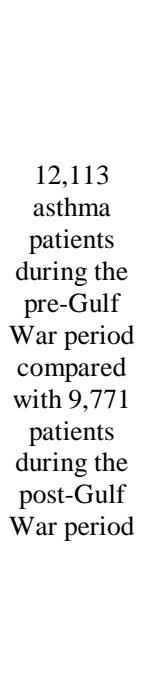 & $\begin{array}{l}\text { During the war, a lot } \\
\text { of oil wells were } \\
\text { burned, giving } \\
\text { suspicion to the } \\
\text { potential for increase } \\
\text { in asthma. No } \\
\text { statistically } \\
\text { significant difference } \\
\text { in hospital } \\
\text { admissions for to } \\
\text { death rates } \\
\text { attributable to } \\
\text { asthma in the pre- } \\
\text { and post-Gulf War } \\
\text { periods in Kuwait. } \\
\text { Notably, the war was } \\
\text { 1990/1991, and no } \\
\text { data is available for } \\
\text { those years, so the } \\
\text { immediate effect } \\
\text { isn't known. }\end{array}$ \\
\hline $\begin{array}{c}\text { Ahmad } \\
(2015)(85)\end{array}$ & Syria & $\begin{array}{c}\text { Syrian } \\
\text { national } \\
\text { health system }\end{array}$ & $\begin{array}{l}\text { Situational } \\
\text { analysis using } \\
\text { document } \\
\text { analysis, key } \\
\text { informant } \\
\text { interviews, } \\
\text { and direct } \\
\text { clinic } \\
\text { observation }\end{array}$ & $\begin{array}{l}\text { Diabetes and } \\
\text { cardiovascular } \\
\text { disease (CVD }\end{array}$ & $\begin{array}{l}\text { October } \\
2009 \text { - } \\
\text { August } \\
2010\end{array}$ & $\begin{array}{l}53 \text { semi- } \\
\text { structured } \\
\text { interviews }\end{array}$ & $\begin{array}{l}\text { The rebuilding of a } \\
\text { post-conflict heath } \\
\text { care system in Syria } \\
\text { may benefit from } \\
\text { insights into the } \\
\text { structural problems } \\
\text { of the pre-crisis } \\
\text { system. Weaknesses } \\
\text { that existed before } \\
\text { the crisis are } \\
\text { compounded by the } \\
\text { current conflict. The } \\
\text { authors suggest an } \\
\text { over reliance on } \\
\text { secondary and } \\
\text { tertiary care for DM } \\
\text { patients with } \\
\text { withdrawal of the } \\
\text { Syrian government } \\
\text { from the public } \\
\text { health clinics, which } \\
\text { led to escalating } \\
\text { healthcare costs and } \\
\text { fostered increasingly } \\
\text { unequal access. }\end{array}$ \\
\hline $\begin{array}{c}\text { Alabed } \\
(2014)(105)\end{array}$ & $\begin{array}{l}\text { Country of } \\
\text { Asylum: } \\
\text { Syria } \\
\text { Country of } \\
\text { Origin: } \\
\text { Palestinian } \\
\text { Territories }\end{array}$ & $\begin{array}{l}\text { Palestinian } \\
\text { refugees } \\
\text { living in } \\
\text { Damascus } \\
\text { attending } \\
\text { three } \\
\text { UNRWA } \\
\text { health clinics }\end{array}$ & $\begin{array}{c}\text { Cross } \\
\text { sectional }\end{array}$ & Diabetes & $\begin{array}{c}\text { August } \\
2008 \text { - } \\
\text { September } \\
2008\end{array}$ & $\begin{array}{l}154 \mathrm{DM} \\
\text { patients }\end{array}$ & $\begin{array}{c}\text { UNRWA clinic } \\
\text { inspections } \\
\text { highlighted } \\
\text { shortages in drug } \\
\text { stocks with } 47.3 \% \text { of } \\
\text { patients reporting } \\
\text { problems accessing } \\
\text { prescribed } \\
\text { medications and } \\
67.7 \% \text { reporting } \\
\text { having to buy } \\
\text { medications at their } \\
\text { own expense at least } \\
\text { once since their } \\
\text { diagnosis. Patients' } \\
\text { knowledge of their } \\
\text { condition was } \\
\text { limited, Patients } \\
\text { were generally } \\
\text { unaware of the } \\
\end{array}$ \\
\hline
\end{tabular}




\begin{tabular}{|c|c|c|c|c|c|c|c|}
\hline & & & & & & & $\begin{array}{l}\text { importance of good } \\
\text { glucose control and } \\
\text { disease management. } \\
\text { Women were more } \\
\text { likely to attend the } \\
\text { clinic than men, with } \\
71 \% \text { of patients } \\
\text { being female. }\end{array}$ \\
\hline $\begin{array}{l}\text { Ali-Shtayeh } \\
(2012)(82)\end{array}$ & $\begin{array}{l}\text { Palestinian } \\
\text { Territories- } \\
\text { West Bank }\end{array}$ & $\begin{array}{c}\text { Patients } \\
\text { attending } \\
\text { outpatient } \\
\text { departments at } \\
\text { Governmental } \\
\text { Hospitals in } 7 \\
\text { towns in the } \\
\text { Palestinian } \\
\text { territories } \\
\text { (Jenin, } \\
\text { Nablus, } \\
\text { Tulkarm, } \\
\text { Qalqilia, } \\
\text { Tubas, } \\
\text { Ramalla, and } \\
\text { Hebron) }\end{array}$ & $\begin{array}{l}\text { Cross- } \\
\text { sectional } \\
\text { survey }\end{array}$ & Diabetes & $\begin{array}{c}\text { August } \\
2010 \text { - May } \\
2011\end{array}$ & $\begin{array}{c}1,883 \mathrm{DM} \\
\text { patients }\end{array}$ & $\begin{array}{c}\text { The use of CAM } \\
\text { differed significantly } \\
\text { between residents of } \\
\text { refugee camps } \\
\text { versus residents of } \\
\text { urban or rural areas } \\
\text { ( } \mathrm{p}=0.034) \text {. Those } \\
\text { who were on CAM } \\
\text { reported they were } \\
\text { using it to slow } \\
\text { down the } \\
\text { progression of the } \\
\text { disease or relieve } \\
\text { symptoms. All } \\
\text { patients with DM } \\
\text { who used CAM were } \\
\text { also on conventional } \\
\text { therapies. }\end{array}$ \\
\hline $\begin{array}{l}\text { AlKasseh } \\
(2014)(84)\end{array}$ & $\begin{array}{c}\text { Palestinian } \\
\text { Territories- } \\
\text { Gaza }\end{array}$ & $\begin{array}{c}\text { Patients at } \\
\text { UNRWA } \\
\text { clinics within } \\
\text { Gaza }\end{array}$ & $\begin{array}{l}\text { Retrospective } \\
\text { case-control } \\
\text { study }\end{array}$ & $\begin{array}{l}\text { Gestational diabetes } \\
\text { (GDM) }\end{array}$ & $\begin{array}{c}\text { March } \\
2011 \text { - June } \\
2011\end{array}$ & $\begin{array}{c}189 \\
\text { postnatal } \\
\text { GDM } \\
\text { women with } \\
189 \\
\text { matched } \\
\text { controls by } \\
\text { age and } \\
\text { place of } \\
\text { residency }\end{array}$ & $\begin{array}{l}\text { The present study } \\
\text { showed that history } \\
\text { of miscarriage more } \\
\text { than once, being } \\
\text { overweight before } \\
\text { pregnancy, history of } \\
\text { stillbirth, history of } \\
\text { caesarean birth and } \\
\text { positive family } \\
\text { history of diabetes } \\
\text { mellitus were } \\
\text { strongly correlated } \\
\text { with developing } \\
\text { GDM. The WHO } \\
\text { criteria for screening } \\
\text { for GDM remains a } \\
\text { good instrument to } \\
\text { identify GDM in } \\
\text { refugee populations } \\
\text { in war-torn countries } \\
\text { (like the Gaza Strip). }\end{array}$ \\
\hline $\begin{array}{c}\text { Amini } \\
(2010)(89)\end{array}$ & Iran & $\begin{array}{c}\text { Completely } \\
\text { blind Iranian } \\
\text { survivors of } \\
\text { the Iran-Iraq } \\
\text { War. }\end{array}$ & $\begin{array}{c}\text { Cross- } \\
\text { sectional study }\end{array}$ & $\begin{array}{c}\text { Multiple NCDs } \\
\text { including } \\
\text { hypertension, } \\
\text { Hypercholesterolemi } \\
\text { a, and erectile } \\
\text { dysfunction }\end{array}$ & 2010 & $\begin{array}{l}250 \text { Iran- } \\
\text { Iraq war } \\
\text { survivors }\end{array}$ & $\begin{array}{l}\text { As blind war } \\
\text { survivors' age, they } \\
\text { will present with a } \\
\text { greater set of } \\
\text { burdens despite their } \\
\text { relatively better } \\
\text { quality of life (QOL) } \\
\text { in the physical } \\
\text { component scale } \\
\text { when compared with } \\
\text { lower limb } \\
\text { amputees. Risk } \\
\text { factors of } \\
\text { cardiovascular attack } \\
\text { such as high blood } \\
\text { pressure and } \\
\text { hypercholesterolemi } \\
\text { a were present: High } \\
\text { systolic and diastolic } \\
\text { blood pressure, }\end{array}$ \\
\hline
\end{tabular}




\begin{tabular}{|c|c|c|c|c|c|c|c|}
\hline & & & & & & & $\begin{array}{c}\text { hearing loss, and } \\
\text { tinnitus had negative } \\
\text { individual } \\
\text { correlations to } \\
\text { (QOL) }(\mathrm{p}=0.016, \\
0.016,0.005, \mathrm{p}< \\
0.0001) . \\
\text { Hypercholesterolemi } \\
\text { a showed significant } \\
\text { correlation to QOL } \\
(\mathrm{p}=0.021) .\end{array}$ \\
\hline $\begin{array}{c}\text { Bijani } \\
(2002)(58)\end{array}$ & Iran & $\begin{array}{c}\text { Iranians } \\
\text { injured by } \\
\text { chemical } \\
\text { weapons } \\
\text { during the } \\
\text { Iraq-Iran war } \\
\text { who are under } \\
\text { services of } \\
\text { the } \\
\text { Mostazafan } \\
\text { and Janbazan } \\
\text { Foundations } \\
\text { of Babol, Iran }\end{array}$ & $\begin{array}{l}\text { Cross- } \\
\text { sectional }\end{array}$ & $\begin{array}{c}\text { Chronic respiratory } \\
\text { diseases }\end{array}$ & $1994-1998$ & 220 patients & $\begin{array}{l}\text { The clinical } \\
\text { evaluations, } \\
\text { radiography, and } \\
\text { PFTs revealed that } \\
\text { the most prevalent } \\
\text { effects of chemical } \\
\text { weapons on } \\
\text { respiratory tract } \\
\text { were chronic } \\
\text { obstructive lung } \\
\text { disease. Victims of } \\
\text { suphorous gas had } \\
\text { demonstrated } \\
\text { involvement of } \\
\text { airways during acute } \\
\text { and chronic phases } \\
\text { of injury, however } \\
\text { over time clinical } \\
\text { manifestations, } \\
\text { radiography, and } \\
\text { PFT gradually } \\
\text { became normal. } \\
\text { Most patients } \\
\text { reported mustard gas } \\
\text { exposure.. Chest X- } \\
\text { Ray was not reliable } \\
\text { to diagnose lung } \\
\text { injury in these } \\
\text { patients. Diagnosis } \\
\text { was completed most } \\
\text { accurately by PFTs. }\end{array}$ \\
\hline $\begin{array}{c}\text { Ben } \\
\text { Romdhane } \\
(2015)(86)\end{array}$ & Tunisia & $\begin{array}{c}\text { Tunisian } \\
\text { national } \\
\text { health system }\end{array}$ & $\begin{array}{l}\text { Situational } \\
\text { analysis }\end{array}$ & $\begin{array}{c}\text { Cardiovascular } \\
\text { disease and diabetes }\end{array}$ & 2010 & $\begin{array}{l}12 \text { key } \\
\text { informants } \\
\text { were } \\
\text { interviewed } \\
\text { and eight } \\
\text { documents } \\
\text { were } \\
\text { reviewed }\end{array}$ & $\begin{array}{c}\text { Weaknesses that } \\
\text { existed before the } \\
2011 \\
\text { Revolution(Arab } \\
\text { Spring) were } \\
\text { compounded during } \\
\text { the revolution. This } \\
\text { study was conducted } \\
\text { prior to political } \\
\text { conflict but written } \\
\text { post-conflict. } \\
\text { Growth of the } \\
\text { private sector } \\
\text { fostered unequal } \\
\text { access by } \\
\text { socioeconomic status } \\
\text { and reduced } \\
\text { coordination and } \\
\text { preparedness of the } \\
\text { health system. } \\
\end{array}$ \\
\hline $\begin{array}{c}\text { Chan } \\
(2009)(124)\end{array}$ & Pakistan & $\begin{array}{c}\text { Patients } \geq 45 \\
\text { years who } \\
\text { attended two } \\
\text { different types } \\
\text { of post- }\end{array}$ & $\begin{array}{c}\text { Comparative } \\
\text { descriptive } \\
\text { study }\end{array}$ & Multiple NCDs & $\begin{array}{c}\text { February } \\
2006 \\
4 \text { months } \\
\text { post- } \\
\text { earthquake } \\
\end{array}$ & $\begin{array}{l}30,000 \\
\text { patients in a } \\
\text { rural site, } \\
\text { and } 382\end{array}$ & $\begin{array}{l}\text { The greatest gap in } \\
\text { health services post- } \\
\text { earthquake in both } \\
\text { sites was non- } \\
\text { communicable }\end{array}$ \\
\hline
\end{tabular}




\begin{tabular}{|c|c|c|c|c|c|c|c|}
\hline & & $\begin{array}{l}\text { earthquake } \\
\text { relief clinics } \\
\text { during a 17- } \\
\text { day field } \\
\text { health needs } \\
\text { assessment in } \\
\text { response to } \\
\text { the } 2005 \\
\text { Kashmir } \\
\text { earthquake }\end{array}$ & & & & $\begin{array}{l}\text { IDPs in a } \\
\text { urban site }\end{array}$ & $\begin{array}{l}\text { disease management. } \\
\text { Clinical records } \\
\text { reviewed in all study } \\
\text { locations showed a } \\
\text { systematic absence } \\
\text { of documentation of } \\
\text { common NCDs. In } \\
\text { rural areas, older } \\
\text { women were less } \\
\text { likely to receive } \\
\text { medical services } \\
\text { while older men } \\
\text { were less likely to } \\
\text { access psychological } \\
\text { services in both } \\
\text { sites. During days } \\
\text { when solely male } \\
\text { doctors provided } \\
\text { clinical services in } \\
\text { the rural site, } \\
\text { medical services } \\
\text { utilization decreased } \\
\text { by } 30 \% \text {. }\end{array}$ \\
\hline $\begin{array}{c}\text { Chan } \\
(2010)(91)\end{array}$ & Pakistan & $\begin{array}{c}\text { Face-to-face, } \\
\text { household- } \\
\text { based survey } \\
\text { conducted } 4 \\
\text { months after } \\
\text { the } 2005 \\
\text { Kashmir, } \\
\text { Pakistan } \\
\text { earthquake } \\
\text { in internally } \\
\text { displaced } \\
\text { camps near } \\
\text { Muzafarabad } \\
\text { city }\end{array}$ & $\begin{array}{c}\text { Cross } \\
\text { sectional }\end{array}$ & Multiple NCDs & $\begin{array}{c}\text { February } \\
2006 \\
4 \text { months } \\
\text { post- } \\
\text { earthquake }\end{array}$ & $\begin{array}{c}167 \\
\text { households }\end{array}$ & $\begin{array}{l}\text { Although the } \\
\text { proportion of the } \\
\text { population with } \\
\text { chronic conditions } \\
\text { was similar across } \\
\text { these studied camps, } \\
\text { 85\% of residents } \\
\text { in the smallest } \\
\text { unofficial camp had } \\
\text { no available drugs } \\
\text { to manage their } \\
\text { chronic medical } \\
\text { conditions as } \\
\text { compared } \\
\text { with their } \\
\text { counterparts residing } \\
\text { in larger rural } \\
\text { unofficial } \\
\text { (40\%) and official } \\
\text { camps (25\%). }\end{array}$ \\
\hline $\begin{array}{c}\text { Doocy } \\
(2013)(115)\end{array}$ & $\begin{array}{l}\text { Country of } \\
\text { Asylum: } \\
\text { Jordan/ } \\
\text { Syria } \\
\text { Country of } \\
\text { Origin: } \\
\text { Iraq }\end{array}$ & $\begin{array}{c}\text { Iraqi } \\
\text { populations } \\
\text { displaced in } \\
\text { Jordan and } \\
\text { Syria }\end{array}$ & $\begin{array}{l}\text { Cross- } \\
\text { sectional }\end{array}$ & $\begin{array}{l}\text { Disability and } \\
\text { multiple NCDs } \\
\text { including } \\
\text { hypertension, } \\
\text { arthritis, diabetes, } \\
\text { chronic respiratory } \\
\text { diseases, and } \\
\text { cardiovascular } \\
\text { disease }\end{array}$ & $\begin{array}{c}\text { October } \\
\text { 2008- } \\
\text { March } \\
2009\end{array}$ & $\begin{array}{l}1200 \text { and } \\
813 \text { Iraqi } \\
\text { households } \\
\text { in Jordan } \\
\text { and Syria, } \\
\text { respectively }\end{array}$ & $\begin{array}{c}\text { Chronic disease } \\
\text { prevalence among } \\
\text { adults was } 51.5 \% \text { in } \\
\text { Syria and } 41.0 \% \text { in } \\
\text { Jordan, with } \\
\text { hypertension and } \\
\text { musculoskeletal } \\
\text { problems most } \\
\text { common. Overall } \\
\text { disability rates were } \\
7.1 \% \text { in Syria and } \\
3.4 \% \text { in Jordan, with } \\
\text { the majority of } \\
\text { disability attributed } \\
\text { to conflict and } \\
\text { depression the } \\
\text { leading cause of } \\
\text { mental health } \\
\text { disability. }\end{array}$ \\
\hline $\begin{array}{c}\text { Doocy } \\
(2015)(114)\end{array}$ & $\begin{array}{l}\text { Country of } \\
\text { Asylum: } \\
\text { Jordan } \\
\text { Country of } \\
\text { Origin: } \\
\text { Syria } \\
\end{array}$ & $\begin{array}{l}\text { Syrian } \\
\text { refugees in } \\
\text { non-camp } \\
\text { settings in } \\
\text { Jordan }\end{array}$ & $\begin{array}{l}\text { Cross- } \\
\text { sectional } \\
\text { survey }\end{array}$ & $\begin{array}{l}\text { Multiple NCDs } \\
\text { including } \\
\text { hypertension, } \\
\text { arthritis, diabetes, } \\
\text { chronic respiratory } \\
\text { diseases, and } \\
\text { cardiovascular } \\
\text { disease }\end{array}$ & $1994-1998$ & $\begin{array}{l}1,550 \\
\text { refugees }\end{array}$ & $\begin{array}{l}\text { More than half of } \\
\text { Syrian refugee } \\
\text { households in Jordan } \\
\text { reported a member } \\
\text { with an NCD. } \\
\text { Among adults, } \\
\text { hypertension } \\
\text { prevalence was the }\end{array}$ \\
\hline
\end{tabular}




\begin{tabular}{|c|c|c|c|c|c|c|c|}
\hline & & & & & & & $\begin{array}{c}\text { highest }(9.7 \%, \text { CI: } \\
8.8-10.6) \text {. While } \\
\text { care-seeking was } \\
\text { high }(85 \%) \text { among } \\
\text { those reporting a } \\
\text { NCD, among those } \\
\text { who did not seek } \\
\text { care, cost was the } \\
\text { primary reason. }\end{array}$ \\
\hline $\begin{array}{l}\text { Ebrahimi } \\
(2014)(37)\end{array}$ & Iran & $\begin{array}{c}\text { Patients with } \\
\text { cardiovascular } \\
\text { and } \\
\text { respiratory } \\
\text { diseases who } \\
\text { received } \\
\text { medical } \\
\text { services from } \\
\text { the Center for } \\
\text { Disaster and } \\
\text { Emergency } \\
\text { Medicine in } \\
\text { Sanandaj, Iran } \\
\text { during dust } \\
\text { event days }\end{array}$ & $\begin{array}{l}\text { Ecological } \\
\text { study }\end{array}$ & $\begin{array}{l}\text { Cardiovascular and } \\
\text { respiratory diseases }\end{array}$ & $\begin{array}{c}\text { March } \\
2009-\text { June } \\
2010\end{array}$ & -- & $\begin{array}{c}\text { The authors } \\
\text { demonstrated a } \\
\text { statistically } \\
\text { significant increase } \\
\text { in emergency } \\
\text { admissions for } \\
\text { cardiovascular } \\
\text { diseases during dust } \\
\text { storm episodes in } \\
\text { Sanandaj, Iran(r } \\
\text { 0.48, p }<0.05) \text {. The } \\
\text { correlation between } \\
\text { respiratory diseases } \\
\text { and dust storm } \\
\text { events were } \\
\text { statistically } \\
\text { insignificant }(0.19) .\end{array}$ \\
\hline $\begin{array}{c}\text { Eljedi } \\
(2006)(71)\end{array}$ & $\begin{array}{c}\text { Palestinian } \\
\text { Territories- } \\
\quad \text { Gaza }\end{array}$ & $\begin{array}{l}\text { Diabetic } \\
\text { patients who } \\
\text { were recruited } \\
\text { from three } \\
\text { refugee camps } \\
\text { in the Gaza } \\
\text { strip with age- } \\
\text { and sex- } \\
\text { matched } \\
\text { controls living } \\
\text { in the same } \\
\text { camps }\end{array}$ & $\begin{array}{l}\text { Cross } \\
\text { sectional }\end{array}$ & Diabetes & $\begin{array}{c}\text { November } \\
2003 \text { - } \\
\text { December } \\
2004\end{array}$ & 197 patients & $\begin{array}{l}\text { Using the World } \\
\text { Health Organization } \\
\text { Quality of Life } \\
\text { questionnaire } \\
\text { (WHOQOL-BREF) } \\
\text { four domains were } \\
\text { strongly reduced in } \\
\text { diabetic patients as } \\
\text { compared to } \\
\text { controls, with } \\
\text { stronger effects in } \\
\text { physical health (36.7 } \\
\text { vs. } 75.9 \text { points of the } \\
0-100 \text { score) and } \\
\text { psychological } \\
\text { domains (34.8 vs. } \\
70.0 \text { ) and weaker } \\
\text { effects in social } \\
\text { relationships (52.4 } \\
\text { vs. } 71.4 \text { ) and } \\
\text { environment } \\
\text { domains (23.4 vs. } \\
\text { 36.2). The impact of } \\
\text { diabetes on health- } \\
\text { related quality of life } \\
\text { was especially } \\
\text { severe among } \\
\text { females and older } \\
\text { subjects. }\end{array}$ \\
\hline $\begin{array}{l}\text { El-Sharif } \\
(2002)(66)\end{array}$ & $\begin{array}{l}\text { Palestinian } \\
\text { Territories- } \\
\text { West Bank }\end{array}$ & $\begin{array}{l}\text { Schoolchildre } \\
\mathrm{n} \text { aged 6-12 } \\
\text { years } \\
\text { attending } 12 \\
\text { schools in the } \\
\text { Ramallah } \\
\text { District of the } \\
\text { Palestinian } \\
\text { West Bank }\end{array}$ & $\begin{array}{l}\text { Cross- } \\
\text { sectional }\end{array}$ & Asthma & $\begin{array}{l}\text { Autumn of } \\
2000\end{array}$ & $\begin{array}{c}3,382 \\
\text { children }\end{array}$ & $\begin{array}{l}\text { Children from } \\
\text { refugee camps were } \\
\text { at a higher risk of } \\
\text { asthma and asthma } \\
\text { symptoms than } \\
\text { children from } \\
\text { neighboring villages } \\
\text { or cities. Physician- } \\
\text { diagnosed asthma } \\
\text { was almost double in } \\
\text { refugee camps than } \\
\text { other places (15.6\% } \\
\text { versus } 8.1 \% \text { in } \\
\text { villages and } 7.3 \% \text { in } \\
\text { cities, pv0.001). }\end{array}$ \\
\hline
\end{tabular}


medRxiv preprint doi: https://doi.org/10.1101/2020.10.15.20213025; this version posted October 20, 2020. The copyright holder for this preprint (which was not certified by peer review) is the author/funder, who has granted medRxiv a license to display the preprint in perpetuity. All rights reserved. No reuse allowed without permission.

\begin{tabular}{|c|c|c|c|c|c|c|c|}
\hline $\begin{array}{l}\text { Forouzan } \\
(2014)(61)\end{array}$ & Iran & $\begin{array}{c}\text { Patients } \\
\text { presenting } \\
\text { with asthma } \\
\text { or } \\
\text { bronchospasm } \\
\text { in western } \\
\text { Iran }\end{array}$ & $\begin{array}{c}\text { Prospective } \\
\text { observational }\end{array}$ & Asthma & $\begin{array}{c}\text { November } \\
2013\end{array}$ & $\begin{array}{c}2,000 \\
\text { patients }\end{array}$ & $\begin{array}{l}\text { Many patients } \\
\text { presented with } \\
\text { bronchospasm after } \\
\text { a thunderstorm. }\end{array}$ \\
\hline $\begin{array}{c}\text { Kallab } \\
(2015)(19)\end{array}$ & $\begin{array}{l}\text { Country of } \\
\text { Asylum: } \\
\text { Lebanon } \\
\text { Country of } \\
\text { Origin: } \\
\text { Syria }\end{array}$ & $\begin{array}{c}\text { Syrian } \\
\text { refugees and } \\
\text { vulnerable } \\
\text { Lebanese } \\
\text { being treated } \\
\text { in } 8 \text { health } \\
\text { facilities run } \\
\text { by Amel } \\
\text { Association } \\
\text { International }\end{array}$ & $\begin{array}{c}\text { Program } \\
\text { implementatio } \\
\text { n reflection }\end{array}$ & $\begin{array}{l}\text { Diabetes and } \\
\text { hypertension }\end{array}$ & $\begin{array}{l}\text { November } \\
\text { 2014- May } \\
2015\end{array}$ & $\begin{array}{c}1,825 \\
\text { patients }\end{array}$ & $\begin{array}{l}\text { Of the } 1,825 \text { patients } \\
\text { enrolled in the } \\
\text { program } \\
\text { hypertension and } \\
\text { diabetes accounted } \\
\text { for } 46 \% \text { and } 27 \% \text { of } \\
\text { cases respectively, } \\
\text { with the remaining } \\
27 \% \text { of patients } \\
\text { presenting with both } \\
\text { diseases. The } \\
\text { program addressed } \\
\text { two main problems } \\
\text { in Lebanon: lack of } \\
\text { access to NCD } \\
\text { services and lack of } \\
\text { proper management } \\
\text { of NCDs. Major } \\
\text { challenges included } \\
\text { insecurity in the } \\
\text { country, patient } \\
\text { transportation cost, } \\
\text { and high workload } \\
\text { for providers. }\end{array}$ \\
\hline $\begin{array}{c}\text { Karrouri } \\
(2014)(69)\end{array}$ & $\begin{array}{l}\text { Country of } \\
\text { Asylum: } \\
\text { Tunisia } \\
\text { Country of } \\
\text { Origin: } \\
\text { Libya }\end{array}$ & $\begin{array}{c}\text { Case of a 10- } \\
\text { year-old } \\
\text { Libyan boy }\end{array}$ & Case report & Diabetes & -- & 1 patient & $\begin{array}{c}\text { Report of a } 10 \text { year } \\
\text { old without personal } \\
\text { or familial diabetes } \\
\text { mellitus history who } \\
\text { developed type } 1 \\
\text { diabetes appeared } \\
\text { immediately } \\
\text { following severe } \\
\text { psychological } \\
\text { trauma. }\end{array}$ \\
\hline $\begin{array}{l}\text { Khader } \\
(2012)(81)\end{array}$ & $\begin{array}{l}\text { Country of } \\
\text { Asylum: } \\
\text { Jordan } \\
\text { Country of } \\
\text { Origin: } \\
\text { Palestinian } \\
\text { Territories }\end{array}$ & $\begin{array}{c}\text { Persons with } \\
\text { DM at Nuzha } \\
\text { PHC Clinic }\end{array}$ & $\begin{array}{l}\text { Retrospective } \\
\text { descriptive } \\
\text { study of the } \\
\text { cohort } \\
\text { reporting } \\
\text { framework to } \\
\text { monitor } \\
\text { burden of } \\
\text { disease and } \\
\text { management }\end{array}$ & Diabetes & $\begin{array}{l}\text { October } \\
\text { 2009- } \\
\text { March } \\
2012\end{array}$ & $\begin{array}{c}2851 \\
\text { patients }\end{array}$ & $\begin{array}{l}\text { A directly observed } \\
\text { therapy (DOTS) } \\
\text { cohort monitoring } \\
\text { system can be } \\
\text { successfully adapted } \\
\text { and used to monitor } \\
\text { and report on } \\
\text { Palestinian refugees } \\
\text { with DM in Jordan. } \\
\text { A sizeable } \\
\text { proportion of DM } \\
\text { patients of the clinic } \\
\text { failed to have } \\
\text { postprandial blood } \\
\text { glucose } \\
\text { measurements, and } \\
\text { BP measurements in } \\
\text { those with comorbid } \\
\text { HTN. The study } \\
\text { demonstrated to the } \\
\text { clinic that they were } \\
\text { either not } \\
\text { performing or not } \\
\text { recording disease- } \\
\text { specific procedures } \\
\text { that should be done } \\
\text { at the investigated } \\
\text { visits - can now } \\
\text { improve on these in }\end{array}$ \\
\hline
\end{tabular}




\begin{tabular}{|c|c|c|c|c|c|c|c|}
\hline & & & & & & & $\begin{array}{l}\text { the future and } \\
\text { monitor thanks to e- } \\
\text { Health system }\end{array}$ \\
\hline $\begin{array}{c}\text { Khader } \\
(2013)(78)\end{array}$ & $\begin{array}{l}\text { Country of } \\
\text { Asylum: } \\
\text { Jordan } \\
\text { Country of } \\
\text { Origin: } \\
\text { Palestinian } \\
\text { Territories }\end{array}$ & $\begin{array}{c}\text { Palestine } \\
\text { refugees } \\
\text { living in } \\
\text { Jordan }\end{array}$ & $\begin{array}{l}\text { Descriptive } \\
\text { cohort study } \\
\text { using routine } \\
\text { data collected } \\
\text { through e- } \\
\text { Health }\end{array}$ & Diabetes & $\begin{array}{l}\text { October } \\
\text { 2009- June } \\
2013\end{array}$ & $\begin{array}{c}12,549 \text { total } \\
\text { patients }\end{array}$ & $\begin{array}{l}\text { High burden of } \\
\text { disease with } \\
\text { predicted annual } \\
\text { additional caseload } \\
\text { is over } 1,000 \\
\text { patients with DM. } \\
\text { Many indicated risk } \\
\text { factors: smoking, } \\
\text { physically inactive, } \\
\text { and obesity. Those } \\
\text { who came had } \\
\text { relatively good } \\
\text { disease control. } \\
\text { Points to the } \\
\text { importance of using } \\
\text { e-Health systems to } \\
\text { monitor and evaluate } \\
\text { and use for strategic } \\
\text { planning. } \\
\text { Complications, } \\
\text { including myocardial } \\
\text { infarction and end- } \\
\text { stage renal disease } \\
\text { were significantly } \\
\text { more common in } \\
\text { males. Females were } \\
\text { more likely to be } \\
\text { obese. }\end{array}$ \\
\hline $\begin{array}{c}\text { Khader } \\
(2014)(41)\end{array}$ & $\begin{array}{l}\text { Country of } \\
\text { Asylum: } \\
\text { Jordan } \\
\text { Country of } \\
\text { Origin: } \\
\text { Palestinian } \\
\text { Territories }\end{array}$ & $\begin{array}{c}\text { Palestine } \\
\text { refugees } \\
\text { living in } \\
\text { Jordan }\end{array}$ & $\begin{array}{l}\text { Retrospective } \\
\text { cohort study } \\
\text { with program } \\
\text { and outcome } \\
\text { data collected } \\
\text { and analyzed } \\
\text { using E-Health }\end{array}$ & Hypertension & $\begin{array}{l}\text { October } \\
\text { 2009- June } \\
2013\end{array}$ & $\begin{array}{c}18,881 \\
\text { patients }\end{array}$ & $\begin{array}{l}\text { Endorses the use of } \\
\text { E口Health and } \\
\text { cohort analysis for } \\
\text { monitoring and } \\
\text { managing patients } \\
\text { with HTN and } \\
\text { DM. High case load } \\
\text { from HTN and } \\
\text { comorbid HTN and } \\
\text { DM(40-50\%) } \\
\text { amongst Palestinian } \\
\text { refugees being } \\
\text { treated at UNRWA } \\
\text { primary health care } \\
\text { clinics in Jordan. } \\
\text { Most common risk } \\
\text { factors included } \\
\text { smoking, physical } \\
\text { inactivity, and } \\
\text { obesity. 33\% of } \\
\text { males smoked, while } \\
\text { more than 50\% of } \\
\text { the women were } \\
\text { physically inactive. } \\
75 \% \text { of women were } \\
\text { obese. }\end{array}$ \\
\hline $\begin{array}{c}\text { Khader } \\
(2014)(80)\end{array}$ & $\begin{array}{l}\text { Country of } \\
\text { Asylum: } \\
\text { Jordan } \\
\text { Country of } \\
\text { Origin: } \\
\text { Palestinian } \\
\text { Territories }\end{array}$ & $\begin{array}{l}\text { Palestinian } \\
\text { refugees } \\
\text { living in } \\
\text { Jordan with } \\
\text { DM attending } \\
\text { Nunzha Clinic }\end{array}$ & $\begin{array}{l}\text { Retrospective } \\
\text { cohort }\end{array}$ & Diabetes & $2010-2013$ & $\begin{array}{l}119 \mathrm{DM} \\
\text { patients }\end{array}$ & $\begin{array}{l}\text { The E-health system } \\
\text { was successful in } \\
\text { monitoring annual } \\
\text { outcomes, measures } \\
\text { of disease control, } \\
\text { and development of } \\
\text { complications in a } \\
\text { cohort of patients } \\
\text { with DM. Three } \\
\text { major findings were: } \\
\text { a progressive loss of }\end{array}$ \\
\hline
\end{tabular}




\begin{tabular}{|c|c|c|c|c|c|c|c|}
\hline & & & & & & & $\begin{array}{l}\text { patients attending } \\
\text { the clinic, mainly } \\
\text { lost to follow-up; } \\
\text { routine } \\
\text { measurements were } \\
\text { always performed, } \\
\text { and there was a } \\
\text { progressive increase } \\
\text { in late-stage } \\
\text { complications, } \\
\text { predominately due to } \\
\text { cardiovascular } \\
\text { disease and stroke. }\end{array}$ \\
\hline $\begin{array}{l}\text { Khader } \\
(2014)(79)\end{array}$ & $\begin{array}{c}\text { Country of } \\
\text { Asylum: } \\
\text { Jordan } \\
\text { Country of } \\
\text { Origin: } \\
\text { Palestinian } \\
\text { Territories }\end{array}$ & $\begin{array}{l}\text { Palestinian } \\
\text { refugees } \\
\text { living in } \\
\text { Jordan with } \\
\text { DM attending } \\
\text { Nunzha Clinic }\end{array}$ & $\begin{array}{l}\text { Retrospective } \\
\text { cohort study }\end{array}$ & Diabetes & 2012 & $\begin{array}{c}2,974 \mathrm{DM} \\
\text { patients }\end{array}$ & $\begin{array}{c}\text { E-Health systems are } \\
\text { useful for } \\
\text { monitoring patients, } \\
\text { since over half of } \\
\text { patients who fail to } \\
\text { attend a scheduled } \\
\text { quarterly } \\
\text { appointment are } \\
\text { declared lost to } \\
\text { follow-up 1 year } \\
\text { later. This suggests a } \\
\text { need for monitoring } \\
\text { and active follow-up }\end{array}$ \\
\hline $\begin{array}{c}\text { Khan } \\
(1997)(55)\end{array}$ & $\begin{array}{c}\text { Country of } \\
\text { Asylum: } \\
\text { Pakistan } \\
\text { Country of } \\
\text { Origin: } \\
\text { Afghanista } \\
\text { n }\end{array}$ & $\begin{array}{l}\text { Patients from } \\
\text { North West } \\
\text { Pakistan and } \\
\text { Afghan } \\
\text { refugees } \\
\text { attending the } \\
\text { Institute of } \\
\text { Radiotherapy } \\
\text { and Nuclear } \\
\text { Medicine, } \\
\text { Peshwar }\end{array}$ & $\begin{array}{c}\text { Cross- } \\
\text { sectional }\end{array}$ & Cancer & $1990-1994$ & $\begin{array}{c}13,359 \\
\text { patients }\end{array}$ & $\begin{array}{c}\text { In male Afghan } \\
\text { refugees, esophageal } \\
\text { cancer represented } \\
16.6 \% \text { of the cases, } \\
\text { compared to only } \\
4.6 \% \text { of the cases in } \\
\text { Pakistani residents. } \\
\text { Similar patterns in } \\
\text { women }(13.1 \% \text { vs. } \\
4.1 \%)\end{array}$ \\
\hline $\begin{array}{c}\text { Khateri } \\
(2003)(88)\end{array}$ & Iran & $\begin{array}{l}\text { Individuals } \\
\text { with } \\
\text { confirmed } \\
\text { exposure to } \\
\text { mustard agent } \\
\text { during the } \\
\text { Iran-Iraq war } \\
\text { of } 1980-1988 \\
\text { and who were } \\
\text { evaluated for } \\
\text { exposure to } \\
\text { mustard agent } \\
\text { by medical } \\
\text { authorities }\end{array}$ & $\begin{array}{c}\text { Retrospective } \\
\text { Cohort }\end{array}$ & $\begin{array}{l}\text { Chronic pulmonary, } \\
\text { ocular, and cutaneous } \\
\text { lesions }\end{array}$ & $1997-2000$ & $\begin{array}{c}34,000 \\
\text { cases }\end{array}$ & $\begin{array}{l}\text { Among patients, } \\
\text { there was a high } \\
\text { degree of pulmonary } \\
\text { disease: } 42.5 \% \text { of } \\
\text { the exposed } \\
\text { population } \\
\text { exhibiting chronic } \\
\text { lung lesions and } \\
\text { associated } \\
\text { symptoms. Ocular } \\
\text { damage, which is } \\
\text { observed to be } \\
\text { present in } 39.3 \% \text { of } \\
\text { mustard exposed } \\
\text { Iranians, is another } \\
\text { major consequence } \\
\text { of exposure to these } \\
\text { agents as a result of } \\
\text { their ease of } \\
\text { absorption through } \\
\text { the unprotected eye. }\end{array}$ \\
\hline $\begin{array}{c}\text { Lari } \\
(2014)(60)\end{array}$ & Iran & $\begin{array}{c}\text { Patients } \\
\text { exposed to } \\
\text { sulfur mustard } \\
\text { gas }\end{array}$ & $\begin{array}{c}\text { Cross } \\
\text { sectional }\end{array}$ & $\begin{array}{c}\text { Chronic obstructive } \\
\text { pulmonary disease } \\
\text { (COPD) }\end{array}$ & $\begin{array}{c}\text { March } \\
2010 \text { - } \\
\text { April } 2011\end{array}$ & 82 patients & $\begin{array}{c}\text { The COPD } \\
\text { Assessment Test } \\
\text { (CAT) was found to } \\
\text { be a valid tool for } \\
\text { assessment of } \\
\text { health-related quality } \\
\text { of life in chemical } \\
\text { warfare patients with } \\
\text { COPD. }\end{array}$ \\
\hline $\begin{array}{c}\text { Leeuw } \\
(2014)(90)\end{array}$ & $\begin{array}{l}\text { Country of } \\
\text { Asylum: } \\
\text { Jordan, }\end{array}$ & $\begin{array}{c}\text { Syrian refugee } \\
\text { households in } \\
\text { Jordan and }\end{array}$ & $\begin{array}{c}\text { Cross } \\
\text { sectional }\end{array}$ & Multiple NCDs & 2013 & $\begin{array}{c}3,202 \\
\text { refugees }\end{array}$ & $\begin{array}{l}\text { Impairments found } \\
\text { in } 22 \% \text { of refugees } \\
\text { and }\end{array}$ \\
\hline
\end{tabular}




\begin{tabular}{|c|c|c|c|c|c|c|c|}
\hline & $\begin{array}{l}\text { Lebanon } \\
\text { Country of } \\
\text { Origin: } \\
\text { Syria } \\
\end{array}$ & Lebanon & & & & & $\begin{array}{c}\text { disproportionately } \\
\text { affecting those over } \\
60 \text { years of age ( } 70 \% \\
\text { with at least } 1 \\
\text { impairment) }\end{array}$ \\
\hline $\begin{array}{c}\text { Mansour } \\
(2008)(76)\end{array}$ & Iraq & $\begin{array}{c}\text { Patients } \\
\text { struggling } \\
\text { with diabetic } \\
\text { control }\end{array}$ & $\begin{array}{c}\text { Cross } \\
\text { sectional }\end{array}$ & Diabetes & $\begin{array}{c}\text { January } \\
2007- \\
\text { December } \\
2007\end{array}$ & $\begin{array}{c}3,522 \\
\text { patients }\end{array}$ & $\begin{array}{l}\text { Patient opinion for } \\
\text { not achieving good } \\
\text { glycemic control } \\
\text { included the } \\
\text { following: } 50.8 \% \\
\text { cases reported no } \\
\text { drug supply or drug } \\
\text { shortage, while } \\
50.2 \% \text { reported high } \\
\text { drugs and/or } \\
\text { laboratory expenses. } \\
30.7 \% \text { percent of } \\
\text { patients said that } \\
\text { they were unaware } \\
\text { of diabetic } \\
\text { complications and } \\
20.9 \% \text { think that } \\
\text { diabetes is an } \\
\text { untreatable disease. } \\
30 \% \text { think that non- } \\
\text { control of their } \\
\text { diabetes is due to } \\
\text { migration after the } \\
\text { war. No electricity } \\
\text { or erratic electricity, } \\
\text { self-monitoring of } \\
\text { blood glucose is not } \\
\text { available, or strips } \\
\text { were not available or } \\
\text { could not be used, } \\
\text { and illiteracy as a } \\
\text { cause was seen in } \\
15 \%, 10.8 \% \text { and } \\
9.9 \% \text { respectively. }\end{array}$ \\
\hline $\begin{array}{c}\text { Mateen } \\
(2012)(30)\end{array}$ & $\begin{array}{l}\text { Country of } \\
\text { Asylum: } \\
\text { Jordan } \\
\text { Country of } \\
\text { Origin: } \\
\text { Iraq }\end{array}$ & $\begin{array}{l}\text { Iraqi refugees } \\
\text { receiving } \\
\text { UNHCR } \\
\text { health } \\
\text { assistance in } \\
\text { Jordan }\end{array}$ & $\begin{array}{c}\text { Cross } \\
\text { sectional }\end{array}$ & $\begin{array}{c}\text { Multiple NCDs } \\
\text { including } \\
\text { hypertension, visual } \\
\text { disturbances, } \\
\text { diabetes, and joint } \\
\text { disorders }\end{array}$ & $\begin{array}{c}\text { January } \\
2010- \\
\text { December } \\
2010\end{array}$ & $\begin{array}{l}7,642 \\
\text { registered } \\
\text { Iraqi } \\
\text { refugees }\end{array}$ & $\begin{array}{c}\text { Among adults } 18 \\
\text { years or older, } 22 \% \\
\text { had hypertension; } \\
11 \% \\
\text { had type II diabetes } \\
\text { mellitus; } 4 \% \text { had } \\
\text { type I diabetes } \\
\text { mellitus; } 10 \% \text { had } \\
\text { visual disturbances; } \\
10 \% \text { had disorders of } \\
\text { lipoprotein } \\
\text { metabolism and } \\
\text { other lipidemias; } 9 \% \\
\text { had other joint } \\
\text { disorders and } 7 \% \\
\text { had chronic ischemic } \\
\text { heart disease. Cancer } \\
\text { care was required by } \\
2 \% \text { of refugees. For } \\
\text { all } \\
\text { refugees as a group, } \\
\text { the largest number of } \\
\text { visits were for } \\
\text { essential } \\
\text { hypertension } \\
\text { (2067 visits); visual } \\
\text { disturbances (1129); } \\
\text { type II diabetes } \\
\text { mellitus (1021); } \\
\text { other joint disorders } \\
\text { (969), and acute }\end{array}$ \\
\hline
\end{tabular}




\begin{tabular}{|c|c|c|c|c|c|c|c|}
\hline & & & & & & & $\begin{array}{l}\text { upper respiratory } \\
\text { infections (952). }\end{array}$ \\
\hline $\begin{array}{l}\text { McKenzie } \\
(2015)(48)\end{array}$ & $\begin{array}{l}\text { Country of } \\
\text { Asylum: } \\
\text { Jordan } \\
\text { Country of } \\
\text { Origin: } \\
\text { Iraq, Syria }\end{array}$ & $\begin{array}{l}\text { Iraqi/Syrian } \\
\text { refugees } \\
\text { residing in } \\
\text { Jordan }\end{array}$ & $\begin{array}{l}\text { Retrospective } \\
\text { cohort }\end{array}$ & $\begin{array}{l}\text { Neuro-psychiatric } \\
\text { disorders }\end{array}$ & 2012-2013 & $\begin{array}{c}223 \\
\text { refugees }\end{array}$ & $\begin{array}{c}\text { Among } \\
\text { neuropsychiatric } \\
\text { applications, stroke } \\
\text { was the most } \\
\text { common diagnosis, } \\
\text { accounting for 16\%. } \\
\text { Brain tumors } \\
\text { accounted for 13\% } \\
\text { of neuropsychiatric } \\
\text { applications and was } \\
\text { the most expensive } \\
\text { diagnosis overall and } \\
\text { per applicant. The } \\
\text { ECC denied six } \\
\text { applications for } \\
\text { reasons of eligibility, } \\
\text { cost, and/or } \\
\text { prognosis. Of the 20 } \\
\text { approved } \\
\text { applications, 15\% (n } \\
=3 \text { ) were approved } \\
\text { for less than the } \\
\text { requested amount, } \\
\text { receiving on average } \\
\text { 39\% of requested } \\
\text { funds. }\end{array}$ \\
\hline $\begin{array}{l}\text { Mirsadraee } \\
(2011)(59)\end{array}$ & Iran & $\begin{array}{c}\text { Patients } \\
\text { whose parents } \\
\text { were exposed } \\
\text { to chemical } \\
\text { warfare }\end{array}$ & Case control & Asthma & -- & $\begin{array}{c}409 \\
\text { children }\end{array}$ & $\begin{array}{l}\text { The prevalence of } \\
\text { asthma was not } \\
\text { significantly } \\
\text { different in the } \\
\text { offspring of } \\
\text { chemical warfare } \\
\text { victims. }\end{array}$ \\
\hline $\begin{array}{c}\text { Mousa } \\
(2010)(29)\end{array}$ & $\begin{array}{l}\text { Country of } \\
\text { Asylum: } \\
\text { Jordan, } \\
\text { Lebanon, } \\
\text { Syria, West } \\
\text { Bank/Gaza } \\
\\
\text { Country of } \\
\text { Origin: } \\
\text { Palestinian } \\
\text { Territories }\end{array}$ & $\begin{array}{l}\text { Refugees } \\
\text { registered by } \\
\text { the United } \\
\text { Nations Relief } \\
\text { and Works } \\
\text { Agency for } \\
\text { Palestine } \\
\text { Refugees in } \\
\text { the Near East } \\
\text { (UNRWA) }\end{array}$ & Case series & $\begin{array}{l}\text { Diabetes and } \\
\text { hypertension }\end{array}$ & June 2007 & $\begin{array}{c}7,762 \\
\text { refugees }\end{array}$ & $\begin{array}{c}\text { A total of } 9 \% \text { of } \\
\text { those screened were } \\
\text { diagnosed with } \\
\text { hypertension or } \\
\text { diabetes. Being older } \\
\text { than } 40 \text { years, obese } \\
\text { or with a positive } \\
\text { family history of } \\
\text { diabetes or } \\
\text { cardiovascular } \\
\text { disease increased the } \\
\text { risk of presenting } \\
\text { with hypertension } \\
\text { and/or } \\
\text { hyperglycemia } 3.5, \\
1.6 \text { and } 1.2 \text { times } \\
\text { respectively. Risk } \\
\text { factors were very } \\
\text { common (obesity } \\
\text { and smoking). }\end{array}$ \\
\hline $\begin{array}{l}\text { Otoukesh } \\
(2012)(42)\end{array}$ & $\begin{array}{l}\text { Country of } \\
\text { Asylum: } \\
\text { Iran } \\
\text { Country of } \\
\text { Origin: } \\
\text { Afghanista } \\
n\end{array}$ & $\begin{array}{l}\text { Afghan } \\
\text { refugees in } \\
\text { Iran }\end{array}$ & $\begin{array}{l}\text { Retrospective } \\
\text { cross sectional }\end{array}$ & $\begin{array}{c}\text { Multiple NCDs } \\
\text { including ophthalmic } \\
\text { diseases, neoplasm, } \\
\text { nephropathies, } \\
\text { ischemic heart } \\
\text { disease, and perinatal } \\
\text { disorders }\end{array}$ & $2005-2010$ & $\begin{array}{c}23,152 \\
\text { refugees }\end{array}$ & $\begin{array}{l}\text { The Afghan refugees } \\
\text { who received } \\
\text { referrals for care } \\
\text { represented a higher } \\
\text { number of women, } \\
\text { age } 15-59 \text { years old, } \\
\text { for ophthalmic } \\
\text { diseases, neoplasms, } \\
\text { and nephropathies. }\end{array}$ \\
\hline $\begin{array}{l}\text { Shamseddin } \\
\text { e (2004)(49) }\end{array}$ & Lebanon & $\begin{array}{l}\text { Lebanese } \\
\text { population } \\
\text { following the } \\
1975-1990 \\
\text { Lebanese } \\
\text { Civil War } \\
\end{array}$ & $\begin{array}{l}\text { Nationwide, } \\
\text { Population- } \\
\text { Based } \\
\text { Prevalence } \\
\text { Study }\end{array}$ & Cancer & 1998 & 4,388 cases & $\begin{array}{l}\text { Among males, the } \\
\text { most frequently } \\
\text { reported cancer was } \\
\text { bladder }(18.5 \%), \\
\text { followed by prostate } \\
(14.2 \%) \text {, and lung }\end{array}$ \\
\hline
\end{tabular}




\begin{tabular}{|c|c|c|c|c|c|c|c|}
\hline & & & & & & & $\begin{array}{c}\text { cancer (14.1\%) } \\
\text { Among females, } \\
\text { breast cancer alone } \\
\text { constituted around } \\
\text { one third of the total } \\
\text { cancer caseload in } \\
\text { the country, } \\
\text { followed by colon } \\
\text { cancer (5.8\%), and } \\
\text { cancer of the corpus } \\
\text { uteri ( } 4.8 \% \text { ). One } \\
\text { limitation of the } \\
\text { study is that the last } \\
\text { and only census } \\
\text { undertaken in } \\
\text { Lebanon was in } \\
1932, \text { and the } \\
\text { population estimates } \\
\text { and projections may } \\
\text { have been subject to } \\
\text { minor } \\
\text { inaccuracies. }\end{array}$ \\
\hline $\begin{array}{c}\text { Sibai } \\
(2001)(20)\end{array}$ & Lebanon & $\begin{array}{l}\text { Lebanese } \\
\text { aged } 50 \text { years } \\
\text { and over } \\
\text { residing in } \\
\text { Beirut, } \\
\text { Lebanon in } \\
1983\end{array}$ & $\begin{array}{l}\text { Retrospective } \\
\text { cohort study }\end{array}$ & $\begin{array}{l}\text { Multiple NCDs } \\
\text { including cancer, } \\
\text { cardiovascular } \\
\text { disease, cancer, and } \\
\text { nephropathies. }\end{array}$ & 1983-1993 & 1,567 cases & $\begin{array}{l}\text { The most important } \\
\text { causes were non- } \\
\text { communicable } \\
\text { diseases, mainly } \\
\text { circulatory disease } \\
(60 \%) \text {; and cancer } \\
(15 \%) \text {. Among } \\
\text { circulatory diseases, } \\
\text { ischaemic heart } \\
\text { disease accounted } \\
\text { for the majority of } \\
\text { the mortality burden } \\
(68 \%) \text { followed by } \\
\text { cerebrovascular } \\
\text { diseases (21\%). In } \\
\text { countries that lack } \\
\text { reliable sources of } \\
\text { mortality data, the } \\
\text { utility of verbal } \\
\text { autopsy can be } \\
\text { viably extended to } \\
\text { cohort studies for } \\
\text { assessing causes of } \\
\text { death. }\end{array}$ \\
\hline $\begin{array}{c}\text { Sibai } \\
(2007)(122)\end{array}$ & Lebanon & $\begin{array}{l}\text { Lebanese } \\
\text { aged } 50 \text { years } \\
\text { and over } \\
\text { residing in } \\
\text { Beirut, } \\
\text { Lebanon }\end{array}$ & $\begin{array}{l}\text { Retrospective } \\
\text { cohort study }\end{array}$ & $\begin{array}{c}\text { Cardiovascular } \\
\text { disease }\end{array}$ & 1984-1994 & 1,567 cases & $\begin{array}{l}\text { Most important } \\
\text { causes of death were } \\
\text { CVD and Cancer. } \\
\text { High adjusted risk of } \\
\text { CVD mortality } \\
\text { associated with } \\
\text { being single (never- } \\
\text { married) versus } \\
\text { married among men } \\
\text { and women }\end{array}$ \\
\hline $\begin{array}{c}\text { Sofeh } \\
(2004)(83)\end{array}$ & $\begin{array}{c}\text { Country of } \\
\text { Asylum: } \\
\text { Peshawar, } \\
\text { Pakistan } \\
\text { Country of } \\
\text { Origin: } \\
\text { Afghanista } \\
\text { n }\end{array}$ & $\begin{array}{c}\text { Afghan } \\
\text { refugees } \\
\text { attending Red } \\
\text { Cross } \\
\text { dispensaries } \\
\text { and hospitals } \\
\text { in Peshawar } \\
\text { Pakistan }\end{array}$ & $\begin{array}{l}\text { Cross- } \\
\text { sectional }\end{array}$ & $\begin{array}{c}\text { Multiple NCDs } \\
\text { including diabetes } \\
\text { mellitus }\end{array}$ & -- & 456 patients & $\begin{array}{c}\text { Out of } 456 \text { patients } \\
\text { examined during the } \\
\text { study, } 255 \text { patients } \\
\text { suffered from DM, } \\
80 \text { with hepatitis, } 69 \\
\text { with nephritis, and } \\
52 \text { with } \\
\text { hyperlipidemia. }\end{array}$ \\
\hline $\begin{array}{c}\text { Strong } \\
(2015)(21)\end{array}$ & $\begin{array}{l}\text { Country of } \\
\text { Asylum: } \\
\text { Lebanon } \\
\end{array}$ & $\begin{array}{c}\text { Syrian } \\
\text { refugees over } \\
\text { age } 60 \\
\end{array}$ & $\begin{array}{c}\text { Cross- } \\
\text { sectional }\end{array}$ & $\begin{array}{l}\text { Multiple NCDs } \\
\text { including } \\
\text { hypertension, }\end{array}$ & $\begin{array}{l}\text { March } \\
2011 \text { - } \\
\text { March }\end{array}$ & $\begin{array}{l}210 \\
\text { refugees }\end{array}$ & $\begin{array}{l}\text { Older refugees } \\
\text { reported a high } \\
\text { burden of chronic }\end{array}$ \\
\hline
\end{tabular}




\begin{tabular}{|c|c|c|c|c|c|c|c|}
\hline & $\begin{array}{c}\text { Country of } \\
\text { Origin: } \\
\text { Syria }\end{array}$ & $\begin{array}{l}\text { residing in } \\
\text { Lebanon and } \\
\text { registered } \\
\text { with either } \\
\text { Caritas } \\
\text { Lebanon } \\
\text { Migrant } \\
\text { Center } \\
\text { (CLMC) or } \\
\text { the Palestinian } \\
\text { Women's } \\
\text { Humanitarian } \\
\text { Organization } \\
\text { (PALWHO) }\end{array}$ & & $\begin{array}{c}\text { diabetes, heart } \\
\text { disease, } \\
\text { hyperlipidemia, } \\
\text { arthritis, and ocular } \\
\text { diseases. }\end{array}$ & 2013 & & $\begin{array}{c}\text { illnesses and } \\
\text { disabilities. } \\
\text { Hypertension was } \\
\text { most common } \\
(60 \%) \text {, followed by } \\
\text { diabetes mellitus } \\
(47 \%) \text {, and heart } \\
\text { disease }(30 \%) \text {. The } \\
\text { burden from these } \\
\text { diseases was } \\
\text { significantly higher } \\
\text { in older Palestinians } \\
\text { compared to older } \\
\text { Syrians, even when } \\
\text { controlling for the } \\
\text { effects of sex and } \\
\text { age. Financial } \\
\text { difficulties were } \\
\text { given as the primary } \\
\text { reason for not } \\
\text { seeking care by } 79 \% \\
\text { of older refugees. }\end{array}$ \\
\hline $\begin{array}{c}\text { Wright } \\
(2010)(56)\end{array}$ & Kuwait & $\begin{array}{l}\text { Kuwaiti } \\
\text { nationals ages } \\
50-69 \text { exposed } \\
\text { to the } 1990 \\
\text { Iraqi invasion }\end{array}$ & $\begin{array}{l}\text { Cross- } \\
\text { sectional }\end{array}$ & Asthma and PTSD & $\begin{array}{c}\text { December } \\
2003 \text { - } \\
\text { January } \\
2005 .\end{array}$ & $\begin{array}{c}5,028 \\
\text { subjects }\end{array}$ & $\begin{array}{l}\text { War-related stressors } \\
\text { were associated with } \\
\text { elevated risk of } \\
\text { incident asthma in } \\
\text { elderly Kuwaiti } \\
\text { civilians exposed to } \\
1990 \text { Iraqi invasion. } \\
\text { Study suggested that } \\
\text { those who reported } \\
\text { highest stress } \\
\text { exposure in the } \\
\text { invasion were more } \\
\text { than twice as likely } \\
\text { to report asthma. } \\
\text { Suggestive of } \\
\text { correlation between } \\
\text { war trauma and } \\
\text { asthma. }\end{array}$ \\
\hline $\begin{array}{c}\text { Yaghi } \\
(2012)(94)\end{array}$ & Lebanon & $\begin{array}{c}\text { Cases of } \\
\text { amputations } \\
\text { in Lebanon }\end{array}$ & $\begin{array}{l}\text { Cross- } \\
\text { sectional }\end{array}$ & Diabetes & $\begin{array}{c}\text { January } \\
2007- \\
\text { December } \\
2007\end{array}$ & $\begin{array}{c}661 \\
\text { amputations }\end{array}$ & $\begin{array}{c}\text { Diabetes and } \\
\text { vascular indications } \\
\text { were not only more } \\
\text { common than } \\
\text { trauma-related } \\
\text { amputation, but both } \\
\text { were associated with } \\
\text { more major surgery } \\
\text { and longer } \\
\text { hospital stay } \\
\text { including conflict } \\
\text { afflicted southern } \\
\text { Lebanon where } \\
\text { trauma, diabetes and } \\
\text { vascular disease } \\
\text { amputations all } \\
\text { occurred at more } \\
\text { than twice the } \\
\text { national rate. }\end{array}$ \\
\hline $\begin{array}{c}\text { Yusef } \\
(2000)(22)\end{array}$ & $\begin{array}{l}\text { Country of } \\
\text { Asylum: } \\
\text { Lebanon } \\
\text { Country of } \\
\text { Origin: } \\
\text { Palestinian } \\
\text { Territories }\end{array}$ & $\begin{array}{l}\text { Diabetic and } \\
\text { hypertensive } \\
\text { patients } \\
\text { attending } \\
\text { UNRWA } \\
\text { primary health } \\
\text { care facilities } \\
\text { in Lebanon }\end{array}$ & $\begin{array}{l}\text { Cross- } \\
\text { sectional }\end{array}$ & $\begin{array}{l}\text { Diabetes and } \\
\text { hypertension }\end{array}$ & 1997 & $\begin{array}{c}2,202 \\
\text { records }\end{array}$ & $\begin{array}{c}\text { Presence of both } \\
\text { diabetes and } \\
\text { hypertension } \\
\text { increased the risk for } \\
\text { late-stage } \\
\text { complications. Only } \\
18.2 \% \text { of diabetic } \\
\text { patients and } 17.7 \% \\
\text { of diabetic patients } \\
\text { with hypertension } \\
\text { were managed by }\end{array}$ \\
\hline
\end{tabular}




\begin{tabular}{|c|c|c|c|c|c|c|c|}
\hline & & & & & & & $\begin{array}{c}\text { lifestyle } \\
\text { modification. About } \\
50 \% \text { of type } 2 \text { and } \\
66 \% \text { of type } 1 \\
\text { patients who were on } \\
\text { insulin were well } \\
\text { controlled. } \\
\text { Medication } \\
\text { shortages may drive } \\
\text { medication choices } \\
\text { for hypertension. }\end{array}$ \\
\hline $\begin{array}{l}\text { Zubaid } \\
(2006)(39)\end{array}$ & Kuwait & $\begin{array}{c}\text { Catchment } \\
\text { area of } \\
\text { Mubarak Al } \\
\text { Kabeer } \\
\text { Hospital }\end{array}$ & Ecological & $\begin{array}{l}\text { Acute myocardial } \\
\text { infarction (AMI) }\end{array}$ & $\begin{array}{l}\text { March } \\
2003\end{array}$ & $\begin{array}{l}1 \text { Missile } \\
\text { Attack } \\
\text { Period } \\
\text { (MAP) and } \\
4 \text { control } \\
\text { periods }\end{array}$ & $\begin{array}{l}\text { The number of } \\
\text { admissions for AMI } \\
\text { was highest during } \\
\text { MAP, } 21 \text { cases } \\
\text { compared to 14-16 } \\
\text { cases in the four } \\
\text { control periods, with } \\
\text { a trend towards } \\
\text { increase during } \\
\text { MAP (incidence rate } \\
\text { ratio=1.59; } 95 \% \text { CI } \\
0.95 \text { to } 2.66, \\
\text { p }<0.07 \text { ). The number } \\
\text { of admissions for } \\
\text { AMI during the first } \\
5 \text { days of MAP was } \\
\text { significantly higher } \\
\text { compared to the first } \\
5 \text { days of the four } \\
\text { control periods } \\
\text { (incidence rate } \\
\text { ratio=2.43; } 95 \% \text { CI } \\
1.23 \text { to } 4.26, \mathrm{p}<0.01 \text { ). } \\
\text { This indicates } \\
\text { missile attacks were } \\
\text { associated with an } \\
\text { increase in the } \\
\text { incidence of AMI. }\end{array}$ \\
\hline
\end{tabular}

Table 9: Characteristics of included publications by region: Western Pacific

\begin{tabular}{|c|c|c|c|c|c|c|c|}
\hline & $\begin{array}{c}\text { Country/ } \\
\text { Territory } \\
\text { of Interest }\end{array}$ & $\begin{array}{c}\text { Target } \\
\text { Population }\end{array}$ & $\begin{array}{l}\text { Type of } \\
\text { Study }\end{array}$ & $\begin{array}{c}\text { NCD } \\
\text { Studied }\end{array}$ & $\begin{array}{c}\text { Years of } \\
\text { Observation }\end{array}$ & $\begin{array}{c}\text { Number of } \\
\text { study } \\
\text { participants }\end{array}$ & Major Findings \\
\hline $\begin{array}{c}\text { An } \\
(2014)(68)\end{array}$ & China & $\begin{array}{l}\text { Adults who } \\
\text { had lived } \\
\text { through the } \\
1976 \\
\text { Tangshan } \\
\text { earthquake } \\
\text { (vs control } \\
\text { Age } 37-60\end{array}$ & $\begin{array}{l}\text { Cross- } \\
\text { sectional }\end{array}$ & Diabetes & $\begin{array}{l}\text { Sept } 2013- \\
\text { Dec } 2013\end{array}$ & 1551 adults & $\begin{array}{l}\text { Earthquake stress linked to } \\
\text { higher incidence of DM } \\
\text { Women more likely to have } \\
\text { diabetes after experiencing } \\
\text { earthquake stressors compared } \\
\text { to men. }\end{array}$ \\
\hline $\begin{array}{c}\text { Chan } \\
(2011)(125)\end{array}$ & China & $\begin{array}{l}\text { Evacuees } \\
\text { from the } \\
2008 \\
\text { Sichuan } \\
\text { earthquake }\end{array}$ & $\begin{array}{l}\text { Descriptive, } \\
\text { cross } \\
\text { sectional } \\
\text { study }\end{array}$ & $\begin{array}{l}\text { Multiple } \\
\text { NCDs } \\
\text { including } \\
\text { diabetes, } \\
\text { hypertension, } \\
\text { heart failure }\end{array}$ & May 2008 & 132 adults & $\begin{array}{l}\text { Chronic health needs constituted } \\
\text { a significant proportion of } \\
\text { emergency care during the acute } \\
\text { phase of the earthquake. } \\
\text { Disaster responders must } \\
\text { consider NCDs as well as } \\
\text { trauma. }\end{array}$ \\
\hline $\begin{array}{c}\text { Chen } \\
(2009)(35)\end{array}$ & China & $\begin{array}{l}\text { Adults who } \\
\text { were in the } \\
\text { West China } \\
\text { Hospital on } \\
\text { the day of } \\
\text { the } 2008 \\
\text { Sichuan } \\
\text { (Wenchuan) } \\
\text { earthquake }\end{array}$ & Case series & Hypertension & May 2008 & 11 patients & $\begin{array}{l}\text { Mean blood pressure and heart } \\
\text { rate increased immediately after } \\
\text { the earthquake, regardless of } \\
\text { gender or pre-existing } \\
\text { hypertension. BP gradually } \\
\text { declined within } 6 \text { hours after the } \\
\text { earthquake and increased again } \\
\text { during aftershocks. }\end{array}$ \\
\hline
\end{tabular}


medRxiv preprint doi: https://doi.org/10.1101/2020.10.15.20213025; this version posted October 20, 2020. The copyright holder for this preprint (which was not certified by peer review) is the author/funder, who has granted medRxiv a license to display the preprint in perpetuity. All rights reserved. No reuse allowed without permission.

\begin{tabular}{|c|c|c|c|c|c|c|c|}
\hline $\begin{array}{c}\text { Hung } \\
(2013)(26)\end{array}$ & China & $\begin{array}{l}\text { Patients } \\
\text { treated by } \\
\text { Hong Kong } \\
\text { Red Cross } \\
\text { three weeks } \\
\text { after the } \\
2008 \\
\text { Sichuan } \\
\text { earthquake } \\
\end{array}$ & $\begin{array}{l}\text { Cross } \\
\text { sectional } \\
\text { chart review }\end{array}$ & $\begin{array}{l}\text { Multiple } \\
\text { NCDs } \\
\text { including } \\
\text { hypertension, } \\
\text { stroke }\end{array}$ & June 2008 & $\begin{array}{l}2,034 \\
\text { patient } \\
\text { encounters }\end{array}$ & $\begin{array}{l}\text { There was a high prevalence of } \\
\text { chronic disease after the } \\
\text { earthquake, especially } \\
\text { hypertension }\end{array}$ \\
\hline $\begin{array}{c}\text { Huynh } \\
(2004)(53)\end{array}$ & Vietnam & $\begin{array}{l}\text { Women } \\
\text { hospitalized } \\
\text { with } \\
\text { invasive } \\
\text { cervical } \\
\text { squamous } \\
\text { cell } \\
\text { carcinoma } \\
\text { (subjects) } \\
\text { and other } \\
\text { extrauterine } \\
\text { cancers } \\
\text { (controls) } \\
\end{array}$ & Case control & Cancer & $\begin{array}{l}\text { June } 1996 \text { - } \\
\text { Sept } 1996\end{array}$ & $\begin{array}{l}145 \text { women } \\
\text { in S. } \\
\text { Vietnam, } 80 \\
\text { women in N } \\
\text { Vietnam }\end{array}$ & $\begin{array}{l}\text { The development of invasive } \\
\text { cervical cancer was significantly } \\
\text { associated with military service } \\
\text { by husbands during the } 2^{\text {nd }} \\
\text { Indochinese War and with parity } \\
\text { status. Geographic and temporal } \\
\text { variation in cervical cancer rates } \\
\text { among Vietnamese women was } \\
\text { associated with the movement of } \\
\text { soldiers. }\end{array}$ \\
\hline $\begin{array}{c}\mathrm{Li} \\
(2010)(118)\end{array}$ & China & $\begin{array}{l}\text { Rural adults } \\
\text { born } \\
\text { between } \\
1954 \text { and } \\
1964 \text { in } \\
\text { selected } \\
\text { communities } \\
\text { from the } \\
2002 \text { China } \\
\text { National } \\
\text { Nutrition } \\
\text { and Health } \\
\text { Survey }\end{array}$ & $\begin{array}{l}\text { Cross- } \\
\text { sectional }\end{array}$ & Diabetes & 2002 & 7,874 adults & $\begin{array}{l}\text { Fetal exposure to severe famine } \\
\text { increases the risk of } \\
\text { hyperglycemia in childhood. } \\
\text { The association is exacerbated } \\
\text { by a nutritionally rich } \\
\text { environment later in life }\end{array}$ \\
\hline $\begin{array}{c}\mathrm{Li} \\
(2011)(109)\end{array}$ & China & $\begin{array}{l}\text { Rural adults } \\
\text { born } \\
\text { between } \\
1954 \text { and } \\
1964 \text { in } \\
\text { selected } \\
\text { communities } \\
\text { from the } \\
2002 \text { China } \\
\text { National } \\
\text { Nutrition } \\
\text { and Health } \\
\text { Survey }\end{array}$ & $\begin{array}{l}\text { Cross- } \\
\text { sectional }\end{array}$ & Diabetes & 2002 & 7,874 adults & $\begin{array}{l}\text { Fetal or infant exposure to } \\
\text { famine increases the risk of } \\
\text { metabolic syndrome in } \\
\text { adulthood. The association is } \\
\text { exacerbated by a western dietary } \\
\text { pattern or being overweight in } \\
\text { adulthood }\end{array}$ \\
\hline $\begin{array}{c}\mathrm{Li} \\
(2012)(117)\end{array}$ & China & $\begin{array}{l}\text { People } \\
\text { exposed to } \\
\text { the 1959- } \\
1961 \\
\text { Chinese } \\
\text { famine and } \\
\text { those not } \\
\text { exposed }\end{array}$ & $\begin{array}{l}\text { Retrospective } \\
\text { cohort }\end{array}$ & $\begin{array}{l}\text { Stomach } \\
\text { cancer }\end{array}$ & 1970-2009 & $\begin{array}{l}\text { Population } \\
\text { level data: } \\
\text { ( } 2.4 \text { million) }\end{array}$ & $\begin{array}{l}\text { Prolonged malnutrition during } \\
\text { early life may increase the risk } \\
\text { of stomach cancer later in life. }\end{array}$ \\
\hline $\begin{array}{c}\text { Marom } \\
(2014)(45)\end{array}$ & Philippines & $\begin{array}{l}\text { People who } \\
\text { survived the } \\
2013 \\
\text { earthquake } \\
\text { and typhoon } \\
\text { (Haiyan) in } \\
\text { the city of } \\
\text { Bogo } \\
\text { (northern } \\
\text { Cebu island) }\end{array}$ & Case series & $\begin{array}{l}\text { Head and } \\
\text { neck tumors }\end{array}$ & 2013 & $\begin{array}{l}1,844 \text { adults } \\
\text { treated at the } \\
\text { field } \\
\text { hospital - } \\
5 \%(85) \text { had } \\
\text { H\&N } \\
\text { tumors }\end{array}$ & $\begin{array}{l}\text { Surgical interventions in pts } \\
\text { with H\&N tumors in a relief } \\
\text { mission can be performed for } \\
\text { therapeutic, palliative and } \\
\text { diagnostic purposes. }\end{array}$ \\
\hline
\end{tabular}


medRxiv preprint doi: https://doi.org/10.1101/2020.10.15.20213025; this version posted October 20, 2020. The copyright holder for this preprint (which was not certified by peer review) is the author/funder, who has granted medRxiv a license to display the preprint in perpetuity. All rights reserved. No reuse allowed without permission.

\begin{tabular}{|c|c|c|c|c|c|c|c|}
\hline $\begin{array}{c}\text { Read } \\
(2015)(46)\end{array}$ & Philippines & $\begin{array}{l}\text { Patients } \\
\text { treated by an } \\
\text { australian } \\
\text { govt } \\
\text { deployed } \\
\text { surgical } \\
\text { team in a } \\
\text { field hosp in } \\
\text { Tacloban for } \\
4 \text { wks after } \\
\text { Typhoon } \\
\text { Haiyan }\end{array}$ & $\begin{array}{l}\text { Cross } \\
\text { sectional }\end{array}$ & Diabetes & Nov 2013 & 131 people & $\begin{array}{l}\text { Sepsis from foot injuries in } \\
\text { diabetic patients constituted an } \\
\text { unexpected majority of the } \\
\text { workload of a foreign } \\
\text { collaborative surgical medical } \\
\text { team in Tacloban in the } \\
\text { aftermath of Typhoon Haiyan }\end{array}$ \\
\hline $\begin{array}{c}\text { Sun } \\
(2013)(27)\end{array}$ & China & $\begin{array}{l}\text { Survivors of } \\
\text { Wenchuan } \\
\text { earthquake } \\
\text { staying in a } \\
\text { temporary } \\
\text { shelter for } \\
\text { more than } 1 \\
\text { year }\end{array}$ & $\begin{array}{l}\text { Cross } \\
\text { sectional }\end{array}$ & Hypertension & $\begin{array}{l}\text { March-May } \\
2009\end{array}$ & 3,230 adults & $\begin{array}{l}\text { Age, family history of } \\
\text { hypertension, sleep quality, } \\
\text { waist-to-hip ratio, BMI and } \\
\text { blood glucose levels are risk } \\
\text { factors for earthquake-induced } \\
\text { hypertension. Mental stress was } \\
\text { not a risk factor. }\end{array}$ \\
\hline $\begin{array}{c}\text { Wagner } \\
(2016)(123)\end{array}$ & Cambodia & $\begin{array}{l}\text { Community } \\
\text { health care } \\
\text { workers in } \\
\text { Siam Reap } \\
\text { province }\end{array}$ & $\begin{array}{l}\text { Cross } \\
\text { sectional }\end{array}$ & $\begin{array}{l}\text { Type } 2 \\
\text { Diabetes }\end{array}$ & .. & 185 & $\begin{array}{l}\text { Community health workers were } \\
\text { able to effectively learn diabetes } \\
\text { prevention curriculum } \\
\text { suggesting that they would be } \\
\text { effective at disseminating the } \\
\text { information }\end{array}$ \\
\hline $\begin{array}{c}\mathrm{Wu} \\
(2015)(96)\end{array}$ & China & $\begin{array}{l}\text { Senior over } \\
\text { age } 60 \\
\text { living in } 8 \\
\text { villages in } \\
\text { China } \\
\text { during a } \\
2011 \text { flood }\end{array}$ & $\begin{array}{l}\text { Cross } \\
\text { sectional } \\
\text { survey }\end{array}$ & $\begin{array}{l}\text { Multiple } \\
\text { NCDs } \\
\text { including } \\
\text { hypertension, } \\
\text { diabetes }\end{array}$ & $\begin{array}{l}\text { February } \\
2012\end{array}$ & $\begin{array}{l}1,183 \\
\text { elderly } \\
\text { patients }\end{array}$ & $\begin{array}{l}\text { There was a marked decline in } \\
\text { health status of the elderly after } \\
\text { a flood. There were greater } \\
\text { detrimental impacts on women } \\
\text { and single elderly }\end{array}$ \\
\hline
\end{tabular}

Table 10: Characteristics of included publications by region: Southeast Asia

\begin{tabular}{|c|c|c|c|c|c|c|c|}
\hline & $\begin{array}{c}\text { Country/Territor } \\
\text { y of Interest }\end{array}$ & $\begin{array}{c}\text { Target } \\
\text { Population }\end{array}$ & $\begin{array}{l}\text { Type of } \\
\text { Study }\end{array}$ & $\begin{array}{l}\text { NCD } \\
\text { Studied }\end{array}$ & $\begin{array}{c}\text { Years of } \\
\text { Observatio } \\
n\end{array}$ & $\begin{array}{c}\text { Number of } \\
\text { study } \\
\text { participant } \\
\text { s }\end{array}$ & Major Findings \\
\hline $\begin{array}{c}\text { Gilder } \\
(2014)(93)\end{array}$ & $\begin{array}{c}\text { Country of } \\
\text { Asylum: Thailand } \\
\text { Country of Origin: } \\
\text { Myanmar }\end{array}$ & $\begin{array}{c}\text { Women } \\
\text { attending the } \\
\text { antenatal care } \\
\text { (ANC) clinic in } \\
\text { Maela refugee } \\
\text { camp on the } \\
\text { Thai-Myanmar } \\
\text { border }\end{array}$ & $\begin{array}{l}\text { Cross } \\
\text { sectional }\end{array}$ & Diabetes & $\begin{array}{l}\text { July } 2011- \\
\text { March } 2012\end{array}$ & 228 women & $\begin{array}{c}\text { The prevalence } \\
\text { of GDM is lower } \\
\text { in this } \\
\text { population } \\
\text { compared with } \\
\text { other } \\
\text { populations, but } \\
\text { still complicates } \\
10 \% \text { of } \\
\text { pregnancies. } \\
\text { Despite the } \\
\text { weight of } \\
\text { evidence for the } \\
\text { benefits of early } \\
\text { diagnosis and } \\
\text { treatment of } \\
\text { GDM, the } \\
\text { absence of a } \\
\text { simple, } \\
\text { inexpensive and }\end{array}$ \\
\hline
\end{tabular}


medRxiv preprint doi: https://doi.org/10.1101/2020.10.15.20213025; this version posted October 20, 2020. The copyright holder for this preprint (which was not certified by peer review) is the author/funder, who has granted medRxiv a license to display the preprint in perpetuity.

All rights reserved. No reuse allowed without permission.

\begin{tabular}{|c|c|c|c|c|c|c|c|}
\hline & & & & & & & $\begin{array}{c}\text { applicable } \\
\text { screening } \\
\text { method remains } \\
\text { a major barrier } \\
\text { to GDM } \\
\text { screening } \\
\text { programs in } \\
\text { refugee camps } \\
\text { and other } \\
\text { resource-poor } \\
\text { settings. }\end{array}$ \\
\hline $\begin{array}{c}\text { Guha- } \\
\text { Sapir(2007) } \\
\text { (64) }\end{array}$ & Indonesia & $\begin{array}{c}\text { Patients } \\
\text { attending an } \\
\text { International } \\
\text { Committee of } \\
\text { the Red } \\
\text { Cross(ICRC) } \\
\text { field hospital in } \\
\text { Aceh, Indonesia, } \\
\text { established } \\
\text { immediately } \\
\text { after the tsunami } \\
\text { in } 2004\end{array}$ & $\begin{array}{l}\text { Cross- } \\
\text { sectional }\end{array}$ & $\begin{array}{l}\text { Multiple } \\
\text { NCDs } \\
\text { including } \\
\text { hypertension } \\
\text {, diabetes, } \\
\text { chronic } \\
\text { respiratory } \\
\text { diseases, } \\
\text { trauma or } \\
\text { injury, and } \\
\text { psychiatric } \\
\text { illness }\end{array}$ & $\begin{array}{c}\text { January } 15, \\
2004- \\
\text { January } 31 \\
2004\end{array}$ & $\begin{array}{l}1,188 \text { study } \\
\text { participants }\end{array}$ & $\begin{array}{c}\text { Chronic diseases } \\
\text { including HTN } \\
\text { and DM } \\
\text { represented } \\
43.5 \% \text { of } \\
\text { consultations } \\
\text { including acute } \\
\text { presentations of } \\
\text { chronic illnesses. } \\
\text { These cases } \\
\text { presented soon } \\
\text { after the hospital } \\
\text { opened and } \\
\text { accounted for } \\
\text { about half of the } \\
\text { consultations. } \\
\text { The largest } \\
\text { diagnostic } \\
\text { groups included: } \\
\text { respiratory } \\
\text { diseases } \\
\text { (21.0\%), other } \\
\text { chronic diseases, } \\
\text { such as diabetes } \\
\text { and hypertension } \\
\text { (17.3\%), trauma } \\
\text { or injury (9.8\%) } \\
\text { and psychiatric } \\
\text { illness (9.7\%). } \\
\text { Females' odds of } \\
\text { acute disease } \\
\text { were } 34 \% \text { lower } \\
\text { than males (95\% } \\
\text { CI: } 16-49 \%, \\
\text { P=0.001) } \\
\text { however were } \\
65 \% \text { more likely } \\
\text { than males to be } \\
\text { diagnosed with a } \\
\text { psychiatric } \\
\text { illness (95\% CI: } \\
11-145 \%, \\
\text { P=0.013). }\end{array}$ \\
\hline
\end{tabular}




\begin{tabular}{|c|c|c|c|c|c|c|c|}
\hline $\begin{array}{c}\text { Khan } \\
(2013)(110)\end{array}$ & Bangladesh & $\begin{array}{c}\text { Respondents } \\
\text { living in flood } \\
\text { and stagnant } \\
\text { water-affected } \\
\text { areas of Dhaka } \\
\text { over } 10 \text { years of } \\
\text { age }\end{array}$ & $\begin{array}{l}\text { Cross- } \\
\text { sectional }\end{array}$ & $\begin{array}{l}\text { Multiple } \\
\text { NCDs }\end{array}$ & $\begin{array}{c}\text { March } 2008 \\
\text {-March } 2009\end{array}$ & $\begin{array}{l}3,207 \text { study } \\
\text { subjects }\end{array}$ & $\begin{array}{c}\text { Respondents } \\
\text { living in flood } \\
\text { and stagnant } \\
\text { water- } \\
\text { affected(FSW) } \\
\text { areas were more } \\
\text { vulnerable than } \\
\text { their non- } \\
\text { affected } \\
\text { counterparts. } \\
\text { While } \\
\text { respondents } \\
\text { living in the } \\
\text { FSW-affected } \\
\text { areas reported } \\
\text { more } \\
\text { communicable } \\
\text { and poor mental } \\
\text { well-being, the } \\
\text { prevalence of } \\
\text { NCDs was } \\
\text { remarkably } \\
\text { lower in the } \\
\text { affected (2.7 \%) } \\
\text { than the non- } \\
\text { affected areas } \\
\text { (4.8\%). } \\
\text { However, FSW } \\
\text { affected area } \\
\text { respondents also } \\
\text { reported a lack } \\
\text { of availability to } \\
\text { be evaluated by } \\
\text { a medical doctor, } \\
\text { which may affect } \\
\text { these results. }\end{array}$ \\
\hline $\begin{array}{c}\text { Kunii } \\
(2002)(62)\end{array}$ & Indonesia & $\begin{array}{l}\text { Patients exposed } \\
\text { to air pollution } \\
\text { in the "haze } \\
\text { disaster" in } \\
\text { Indonesia } \\
\text { following large } \\
\text { forest fires } \\
\text { throughout } \\
\text { Indonesia }\end{array}$ & $\begin{array}{c}\text { Cross } \\
\text { sectional }\end{array}$ & $\begin{array}{l}\text { Chronic } \\
\text { Respiratory } \\
\text { Diseases } \\
\text { including } \\
\text { asthma }\end{array}$ & $\begin{array}{c}\text { September } \\
1997 \text { - } \\
\text { October } \\
1997\end{array}$ & $\begin{array}{c}543 \text { study } \\
\text { subjects }\end{array}$ & $\begin{array}{l}\text { Patients had } \\
\text { increased } \\
\text { respiratory } \\
\text { issues after a } \\
\text { large forest fire } \\
\text { disaster, } \\
\text { especially the } \\
\text { elderly. Wearing } \\
\text { a high-quality } \\
\text { face mask was } \\
\text { protective (vs } \\
\text { handkerchief or } \\
\text { simple surgical } \\
\text { mask). Almost } \\
\text { all of the } \\
\text { respondents } \\
\text { (98.7\%) } \\
\text { developed or } \\
\text { suffered from an } \\
\text { exacerbation of } \\
\text { symptoms, and } \\
91.3 \% \text { had } \\
\text { respiratory } \\
\text { symptoms. Most } \\
\text { of the health } \\
\text { problems were } \\
\text { mild, but } 13.1 \% \\
\text { perceived their } \\
\text { health problems } \\
\text { as severe and } \\
49.2 \% \text { reported } \\
\text { that the health } \\
\text { problems } \\
\text { disturbed their }\end{array}$ \\
\hline
\end{tabular}


medRxiv preprint doi: https://doi.org/10.1101/2020.10.15.20213025; this version posted October 20, 2020. The copyright holder for this preprint (which was not certified by peer review) is the author/funder, who has granted medRxiv a license to display the preprint in perpetuity.

All rights reserved. No reuse allowed without permission.

\begin{tabular}{|c|c|c|c|c|c|c|c|}
\hline & & & & & & & daily life. \\
\hline $\begin{array}{c}\text { Molla } \\
(2014)(67)\end{array}$ & Bangladesh & $\begin{array}{l}\text { Children under } 5 \\
\text { years of age } \\
\text { categorized as } \\
\text { climate refugees } \\
\text { in Dhaka with } \\
\text { diarrhea and } \\
\text { asthma }\end{array}$ & $\begin{array}{c}\text { Cross } \\
\text { sectional }\end{array}$ & $\begin{array}{c}\text { Asthma and } \\
\text { diarrheal } \\
\text { diseases }\end{array}$ & $\begin{array}{c}\text { September } \\
2012- \\
\text { November } \\
2012\end{array}$ & $\begin{array}{c}410 \\
\text { households }\end{array}$ & $\begin{array}{l}\text { Asthma caused a } \\
\text { significantly } \\
\text { higher number of } \\
\text { disability } \\
\text { adjusted life } \\
\text { years (DALYs) } \\
\text { lost in the group } \\
\text { displaced due to } \\
\text { climate change } \\
\text { in comparison to } \\
\text { controls. } \\
\text { Associated } \\
\text { contributing } \\
\text { factors included } \\
\text { overcrowding } \\
\text { and improper } \\
\text { household } \\
\text { ventilation for } \\
\text { domestic } \\
\text { cooking or } \\
\text { burning among } \\
\text { climate change } \\
\text { refugees. }\end{array}$ \\
\hline $\begin{array}{c}\text { Ramachandra } \\
\mathrm{n}(2006)(70)\end{array}$ & India & $\begin{array}{c}\text { Tsunami } \\
\text { affected } \\
\text { population of } \\
\text { Chennai(Madras } \\
\text { ) in Southern } \\
\text { India aged } 20 \\
\text { and above }\end{array}$ & $\begin{array}{l}\text { Retrospectiv } \\
\text { e cohort }\end{array}$ & Diabetes & $\begin{array}{l}\text { April 2005- } \\
\text { June } 2005\end{array}$ & $\begin{array}{c}1,184 \\
\text { tsunami } \\
\text { affected } \\
\text { subjects, } \\
1,176 \\
\text { controls }\end{array}$ & $\begin{array}{l}\text { Undetected } \\
\text { diabetes and } \\
\text { impaired glucose } \\
\text { tolerance were } \\
\text { higher in the } \\
\text { tsunami-hit area } \\
\text { as compared to } \\
\text { controls. } \\
\text { Diabetes } \\
\text { prevalence was } \\
\text { found to be } \\
\text { similar in the } \\
\text { tsunami affected } \\
\text { population and } \\
\text { control group. } \\
\text { Women reported } \\
\text { higher stress } \\
\text { scores and } \\
\text { demonstrated a } \\
\text { higher } \\
\text { prevalence of } \\
\text { impaired glucose } \\
\text { tolerance as } \\
\text { compared to } \\
\text { their male } \\
\text { counterparts. }\end{array}$ \\
\hline
\end{tabular}


medRxiv preprint doi: https://doi.org/10.1101/2020.10.15.20213025; this version posted October 20, 2020. The copyright holder for this preprint (which was not certified by peer review) is the author/funder, who has granted medRxiv a license to display the preprint in perpetuity.

All rights reserved. No reuse allowed without permission.

\begin{tabular}{|c|c|c|c|c|c|c|c|}
\hline $\begin{array}{l}\text { Redwood- } \\
\text { Campbell } \\
(2006)(65)\end{array}$ & Indonesia & $\begin{array}{l}\text { Patients } \\
\text { registering in the } \\
\text { ICRC field } \\
\text { hospital in } \\
\text { Banda Aceh } \\
\text { after the tsunami }\end{array}$ & $\begin{array}{c}\text { Cross } \\
\text { Sectional }\end{array}$ & $\begin{array}{c}\text { Multiple } \\
\text { NCDs } \\
\text { including } \\
\text { respiratory, } \\
\text { psychiatric, } \\
\text { endocrine, } \\
\text { urological, } \\
\text { and } \\
\text { neurologic } \\
\text { diseases }\end{array}$ & March 2005 & 271 patients & $\begin{array}{l}12 \% \text { of the } \\
\text { problems seen in } \\
\text { the clinic } 9 \\
\text { weeks after the } \\
\text { tsunami were } \\
\text { directly related } \\
\text { to the tsunami. } \\
\text { Majority of } \\
\text { patients were } \\
\text { male, the } \\
\text { problems were } \\
\text { urologic, } \\
\text { digestive, } \\
\text { respiratory and } \\
\text { musculoskeletal } \\
\text { in that order. } \\
24 \% \text { had } 4 \text { or } \\
\text { more } \\
\text { depression/PTS } \\
\text { D symptoms. }\end{array}$ \\
\hline
\end{tabular}


medRxiv preprint doi: https://doi.org/10.1101/2020.10.15.20213025; this version posted October 20, 2020. The copyright holder for this preprint

(which was not certified by peer review) is the author/funder, who has granted medRxiv a license to display the preprint in perpetuity.

All rights reserved. No reuse allowed without permission. 
medRxiv preprint doi: https://doi.org/10.1101/2020.10.15.20213025; this version posted October 20, 2020. The copyright holder for this preprint

(which was not certified by peer review) is the author/funder, who has granted medRxiv a license to display the preprint in perpetuity.

All rights reserved. No reuse allowed without permission.

PRISMA 2009 Flow Diagram

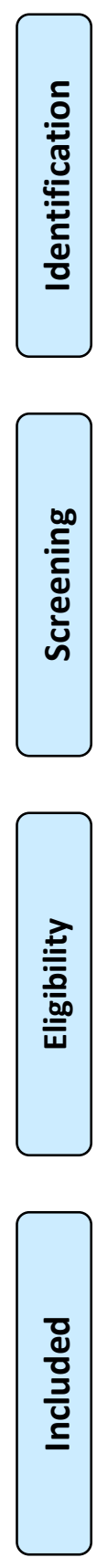

Records identified through database

searching after duplicates removed

$$
\begin{aligned}
& (n=4430) \\
& \mathrm{SSCl}=1379
\end{aligned}
$$

Medline/Ovid $=1690$

PubMed $=673$

Global Health $=88$
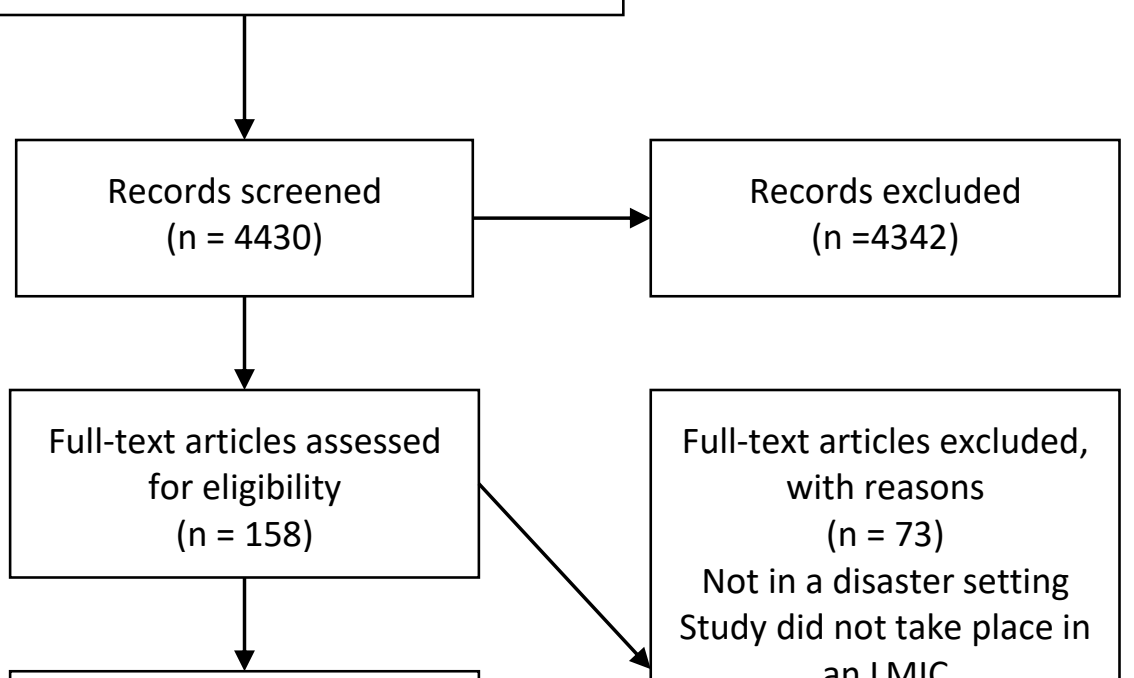

Studies included in qualitative synthesis

$$
(n=85)
$$

Full-text articles excluded, with reasons

$$
(n=73)
$$

Not in a disaster setting Study did not take place in an LMIC

Study did not include information pertaining to NCDs

Study methodology was a review article 